\title{
MAXDOSE-SR: A Routine Release Atmospheric Dose Model Used at SRS
}

by

\author{
A. A. Simpkins \\ Westinghouse Savannah River Company \\ Savannah River Site \\ Aiken, South Carolina 29808
}

\section{RECEIVED \\ FFR 232000 \\ OSTI}

This paper was prepared in connection with work done under the above contract number with the U.S. Department of Energy. By acceptance of this paper, the publisher and/or recipient acknowledges the U.S. Government's right to retain a nonexclusive, royalty-free license in and to any copyright covering this paper, along with the right to reproduce and to authorize others to reproduce all or part of the copyrighted paper. 


\section{MAXDOSE-SR: A ROUTINE-RELEASE ATMOSPHERIC DOSE MODEL USED AT SRS}

Ali A. Simpkins

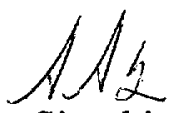

Ali A. Simpkins

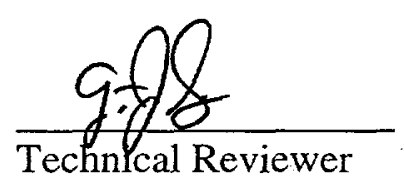

October 1999

Westinghouse Savannah River Company Savannah River Site

Aiken, SC 29808
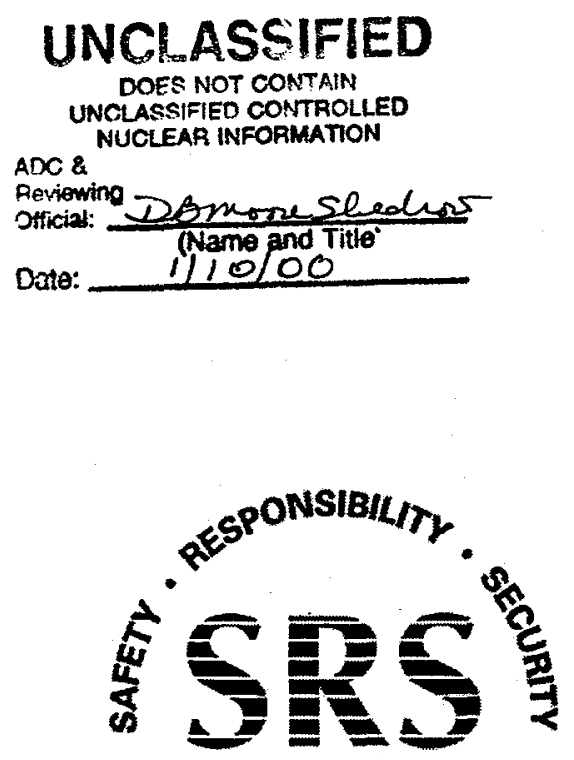

SAVANNAH RIVER SITE 


\section{DISCLAIMER}

This report was prepared as an account of work sponsored by an agency of the United States Government. Neither the United States Government nor any agency thereof, nor any of their employees, makes any warranty, express or implied, or assumes any legal liability or responsibility for the accuracy, completeness, or usefulness of any information, apparatus, product or process disclosed, or represents that its use would not infringe privately owned rights. Reference herein to any specific commercial product, process or service by trade name, trademark, manufacturer, or otherwise does not necessarily constitute or imply its endorsement, recommendation, or favoring by the United States Government or any agency thereof. The views and opinions of authors expressed herein do not necessarily state or reflect those of the United States Government or any agency thereof.

This report has been reproduced directly from the best available copy.

Available for sale to the public, in paper, from: U.S. Department of Commerce, National Technical Information Service, 5285 Port Royal Road, Springfield, VA 22161, phone: (800) 553-6847

fax: (703) 605-6900

email: orders@ntis.fedworld.gov

online ordering: http://www.ntis.gov/ordering.htm

Available electronically at http://www.doe.gov/bridge

Available for a processing fee to U.S. Department of Energy and its contractors, in paper, from: U.S. Department of Energy, Office of Scientific and Technical Information, P.O. Box 62, Oak Ridge, TN 37831-0062, phone: (865) 576-8401

fax: (865) 576-5728

email: reports@adonis.osti.gov 


\section{DISCLAIMER}

Portions of this document may be illegible in electronic image products. Images are produced from the best available original document. 
Key Words

Atmospheric Dispersion

Dose Determination

Atmospheric Releases

Retention: Lifetime

MAXDOSE-SR: A ROUTINE-RELEASE ATMOSPHERIC DOSE MODEL USED AT SRS

A. A. Simpkins

Issued: October 1999

SRTC

SAVANNAH RIVER TECHNOLOGY CENTER

AIKEN, SC 29808

Westinghouse Savannah River Company

Savannah River Site

Aiken, SC 29808

PREPARED FOR THE U.S. DEPARTMENT OF ENERGY UNDER CONTRACT NO. DE-AC09-96SR18500 


\section{ABSTRACT}

MAXDOSE-SR is a PC version of the dosimetry code MAXIGASP, which was used to calculate doses to the maximally exposed offsite individual for routine atmospheric releases of radioactive material at the Savannah River Site (SRS). Complete code description, verification of models, and user's manual have been included in this report. Minimal input is required to run the program, and site specific parameters are used when possible. 


\section{TABLE OF CONTENTS}

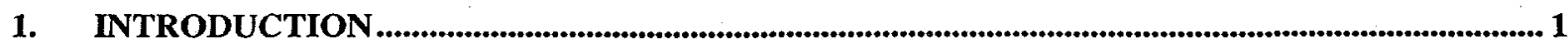

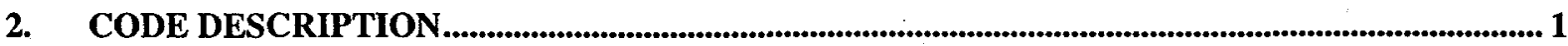

2.1. XOQDOQ

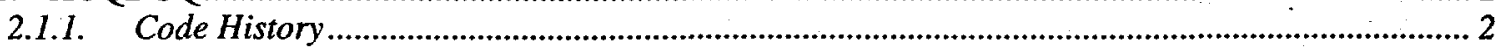

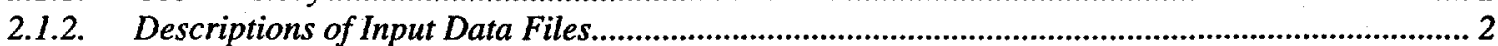

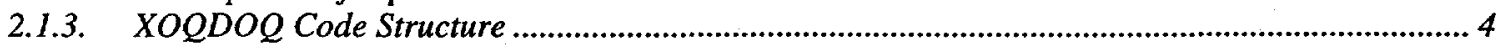

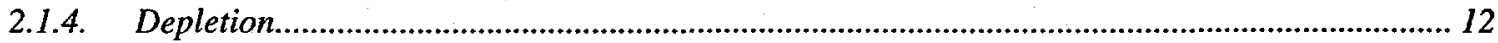

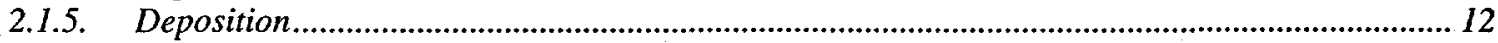

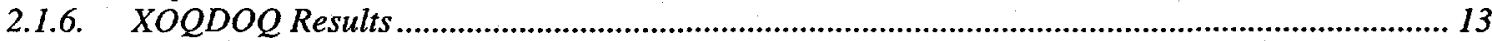

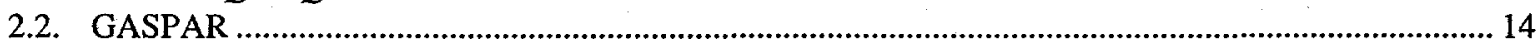

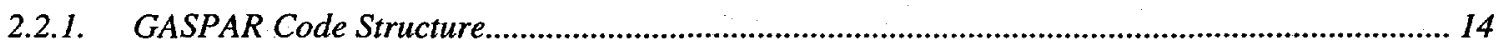

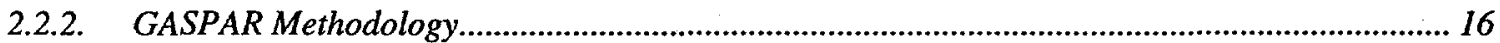

2.2.3. Nuclide Concentrations In The Atmosphere …..................................................................... 16

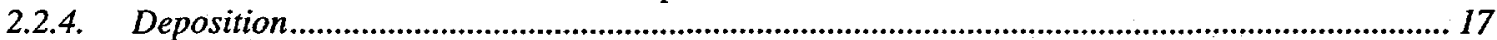

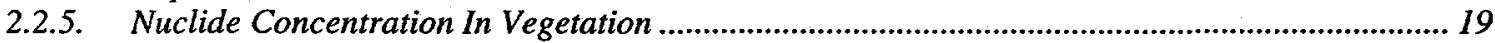

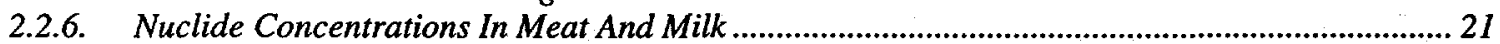

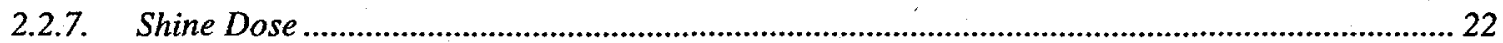

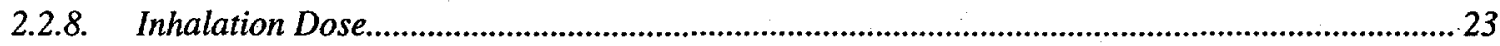

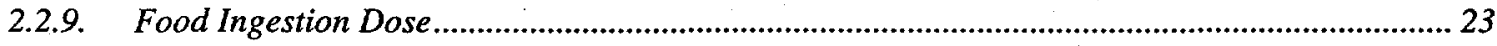

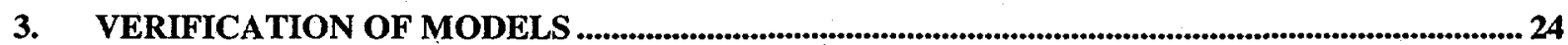

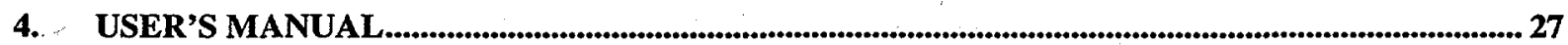

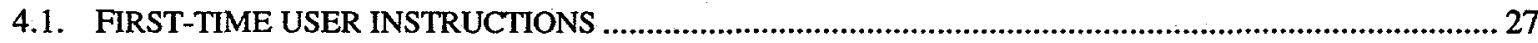

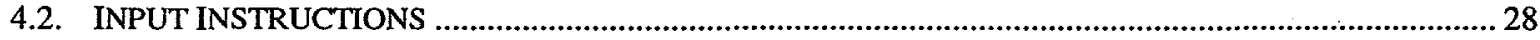

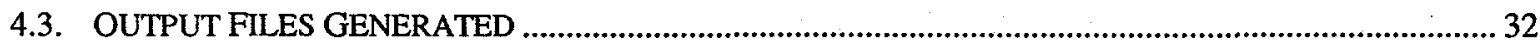

4.3.1. MAXDOSE.DOC

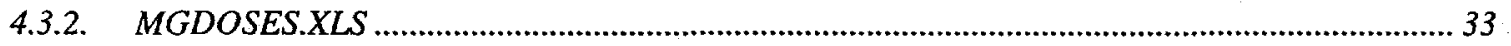

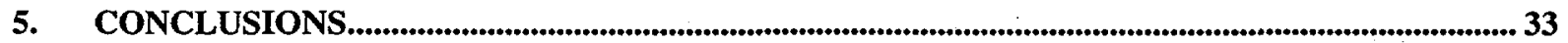

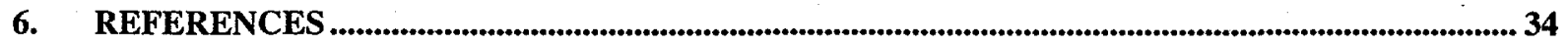




\section{LIST OF TABLES}

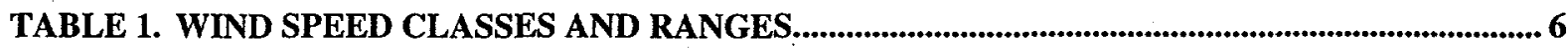

TABLE 2. VALUES USED TO CALCULATE VERTICAL DIFFUSION COEFFICIENTS (SEE EQ 7) 8

TABLE 3. VALUES OF A FOR HORIZONTAL DIFFUSION COEFFICIENTS ......................................9

TABLE 4. PARAMETERS FOR VEGETATION CONCENTRATIONS ..................................................... 21

TABLE 5. PARAMETERS IN GASPAR FOR MEAT AND MILK INGESTION DOSE

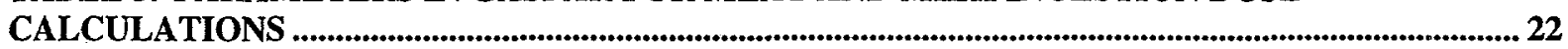

TABLE 6. CONSUMPTION PARAMETERS (HAMBY 1991) ..................................................................... 24

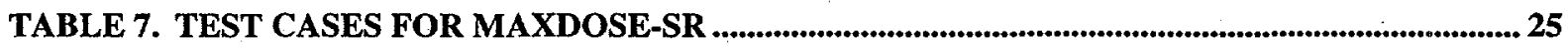

TABLE 8. RESULTS OF TEST CASE COMPARISONS .....................................................................26

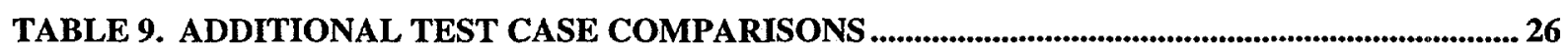

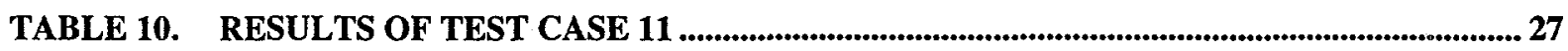

TABLE 11. STACK COORDINATES FOR MAJOR FACILITIES ONSITE........................................ 31

\section{LIST OF FIGURES}

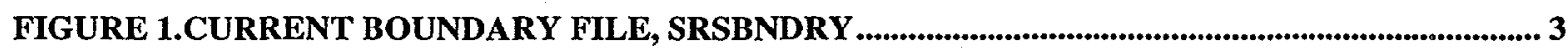

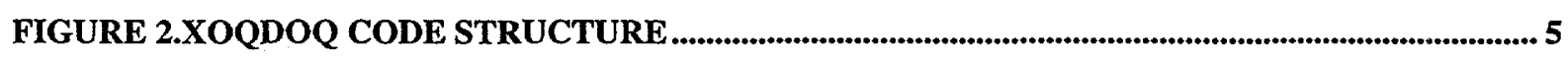

FIGURE 3.XOQDOQ TREATMENT OF CROSS-OVER POINTS ........................................................... 13

FIGURE 4.RGASPAR CODE LAYOUT ..................................................................................................... 15

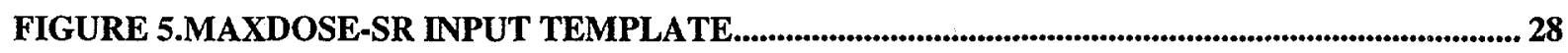




\title{
MAXDOSE-SR: A ROUTINE RELEASE ATMOSPHERIC DOSE MODEL USED AT SRS
}

\author{
By A. A. Simpkins \\ Westinghouse Savannah River Company \\ Savannah River Site \\ Aiken, SC 29808
}

\section{INTRODUCTION}

MAXDOSE-SR is used to calculate dose to the maximally exposed offsite individual (MEI) following routine releases of atmospheric radioactivity. MAXDOSE-SR is a personal computer (PC) version of MAXIGASP, which resided on the IBM Mainframe. MAXDOSESR follows US Nuclear Regulatory Commission (USNRC) Regulatory Guides 1.109 and 1.111. (USNRC 1977a,1977b). The bases for MAXDOSE-SR are USNRC developed codes XOQDOQ (Sagendorf 1982) and GASPAR (Eckerman 1980). For use at the Savannah River Site (SRS), these two codes were combined into one, and site specific parameters were added where possible. MAXIGASP has been verified for use at SRS, and with the change to MAXDOSE-SR on the PC, the verification process was. repeated to ensure proper execution of the code. Code description and user's manual also have been included. Transference of MAXIGASP to the PC will allow for greater ease of execution and greater reliability of code access.

\section{CODE DESCRIPTION}

MAXDOSE-SR contains the following modules (or subroutines): MGPROTEM, MGPREXOQ, XOQDOQ, MGPREGAS, RGASPAR, and MGDOSES2. A brief summary of each follows.

MGPROTEM -input template is read, printed, and written to a file.

MGPREXOQ -reads in data pertaining to boundary coordinates, terrain, and meteorology.

XOQDOQ - calculates the relative air concentrations $(\chi / Q s)$ and relative deposition rates (D/Qs) for each of the boundary points.

MGPREGAS -reads the input file created by MGPROTEM and also reads an input file MGPREGAS.DAT that contains site specific data mostly concerning usage parameters.

RGASPAR -calculates pathway and organ specific doses and writes the unformatted data to an output file.

MGDOSES2 -writes the results in the requested format. 
The main modules (XOQDOQ and RGASPAR) will be discussed in detail. It is important to note that XOQDOQ and GASPAR were originally written as two different programs and were not designed to work together. As a result, some of the calculations performed in GASPAR are to modify results from XOQDOQ so that they may be used correctly to calculate dose.

\subsection{XOQDOQ}

\subsubsection{Code History}

The XOQDOQ computer program was developed for use by the USNRC to evaluate atmospheric releases from commercial nuclear power operations. The calculations performed by XOQDOQ are those established in the USNRC Regulatory Guide 1.111 for the release of an effluent from a stack or vent under conditions of constant wind direction. A straight-line Gaussian plume model is used, and the plume is assumed to be depleted by dry deposition and radioactive decay.

XOQDOQ was originally developed by J. Sagendorf, National Oceanic and Atmospheric Administration (NOAA) and J. Gnoll, USNRC. XOQDOQ was modified by W. Pillinger in 1983 and 1984 for use at SRS. The changes were primarily associated with expanding arrays and changing read/write statements to make it possible for XOQDOQ to calculate relative concentrations (1) at specific points along the SRS boundary for "maximum" and "average" individuals, and (2) within compass sector regions for population dose assessments (used in a population dose program). In addition, an option was invoked which constrains sector-arc average relative air concentrations $(\chi / Q s)$ to values less than plume centerline $\chi / Q s$.

Additional modifications were made by L. Bauer in 1990. The subroutines called by XOQDOQ to calculate $\chi / Q$ s from short-term releases were removed from the code. XOQDOQ is not the best available code for estimating $\chi / Q s$ from purges or process upsets. This step prevented the unauthorized use of XOQDOQ for such calculations.

\subsubsection{Descriptions of Input Data Files}

All of the data files called upon by XOQDOQ are identified in Appendix A. The three types of data calls made by XOQDOQ include the following:

1) SRS Boundary Data

2) Regional Terrain Data

3) SRS Meteorological Data

\subsubsection{SRS Boundary Data}

The current boundaries of the SRS are recognized by XOQDOQ as 875 pairs of SRS Easting and Northing coordinates, which is the local coordinate system used at SRS. These coordinates have been reviewed for accuracy and approved for use (Bauer 1990). The perimeter of the site, as drawn by the boundary file SRSBNDRY.DAT, is shown in Figure 1. 
The file starts with a point under the 'nose' on the west side of the site and proceeds clockwise around the boundary.

Within XOQDOQ, the minimum distance from the release point to the site boundary is determined for each of the sixteen sectors. First, the 875 pairs of boundary coordinates, are reduced to 320 equally spaced points along the perimeter. The point in a given sector that is closest to the release point is selected based on the smallest distance to 1) any of the boundary points, 2) any of the line segments connecting the boundary points or 3) the two intersections of the compass sector with the perimeter. This distance is then used to calculate the maximally exposed individual dose for each sector.

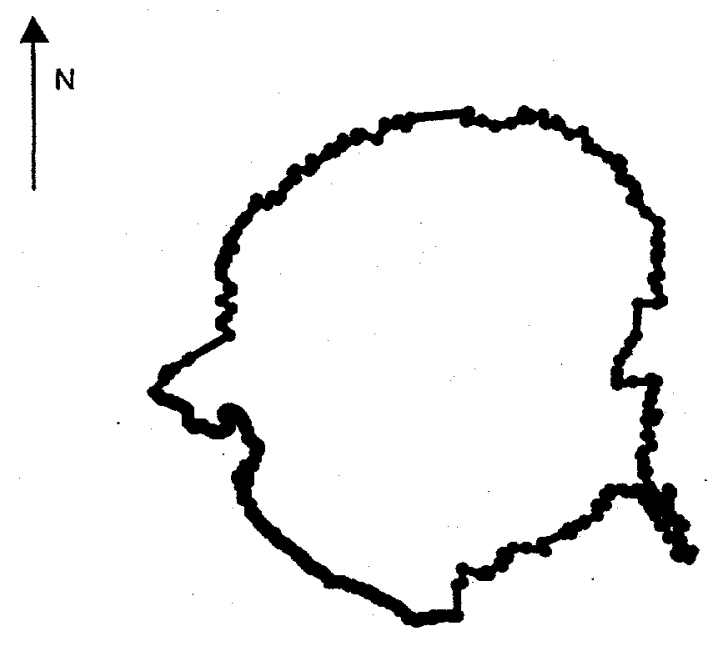

Figure 1. Current Boundary File, SRSBNDRY

\subsubsection{Regional Terrain data}

The height of the plume as it travels from the release point may be adjusted to account for changes in terrain. The terrain file is a binary file called 'TPGY100.bin'. This terrain database is a product of Oak Ridge National Laboratories and contains elevations above mean sea level referenced by coordinates of latitude and longitude. These data are used to develop an array of maximum changes in elevation, relative to the release point's elevations. This array is then called to determine the reduction in plume height required for a specific compass sector and downwind location. The plume height is reduced to account for the fact that if the plume is traveling in a straight line and a receptor is standing on elevated ground, they are closer to the plume. 


\subsubsection{SRS Meteorological data}

XOQDOQ has the ability to access wind speed, wind direction, and atmospheric stability data collected from one of seven onsite meteorological towers. The towers are instrumented at 61 meters above ground level, which is the height of the primary reactor and separations areas stacks. The towers are equipped with cup anemometers to measure wind speed, and with bivanes to measure the horizontal and vertical components of wind direction. Currently, XOQDOQ accesses data files representing meteorological data for the period of 1992-1996. The meteorological monitoring program in use at the SRS has been described in more detail in Parker and Addis (1993). The collection and quality assurance of these data are the responsibility of the Nonproliferation Technology Section (NTS) of SRTC.

XOQDOQ uses meteorological data in the form of joint frequency distributions of wind direction, wind speed range, and atmospheric stability class for each of the sixteen 22.5 degree compass sectors. The turbulence typing scheme used is the Pasquill-Gifford stability classification system.

The USNRC recommends the collection of mixing height data. Mixing, sometimes called inversion, height is the distance above the ground in which the plume is essentially trapped due to temperature inversion. Vertical diffusion is typically limited to the value of the mixing height within XOQDOQ. Mixing height is not routinely measured onsite and is not a user-specified variable in XOQDOQ. The maximum vertical plume dispersion allowed by the code is $1000 \mathrm{~m}$. However, regional compiled data show that monthly average mixing heights are generally greater than this value except during the months of December and January (Garrett 1981). Although the averages for these winter months were found to be lower than $1000 \mathrm{~m}$, this is not believed to impact significantly the calculation of annual average $\chi / Q$ s.

\subsubsection{XOQDOQ Code Structure}

The structure of XOQDOQ is shown in Figure 2 for all of the main subroutines. The calculations performed by major subroutines are described in the following sections. More detailed discussions of XOQDOQs treatment of depletion, deposition, and plume rise also follow.

XOQDOQ is programmed such that it can be used by MAXDOSE-SR or POPDOSE-SR, which is used for population dose calculations.

\subsubsection{Subroutine Description}

ADJUST - The subroutine adjusts effective plume height to correct for terrain changes using the terrain file that was discussed above. Such modifications are required to establish which series of depletion/deposition curves are to be read at a given downwind location. 
Figure 2. XOQDOQ Code Structure

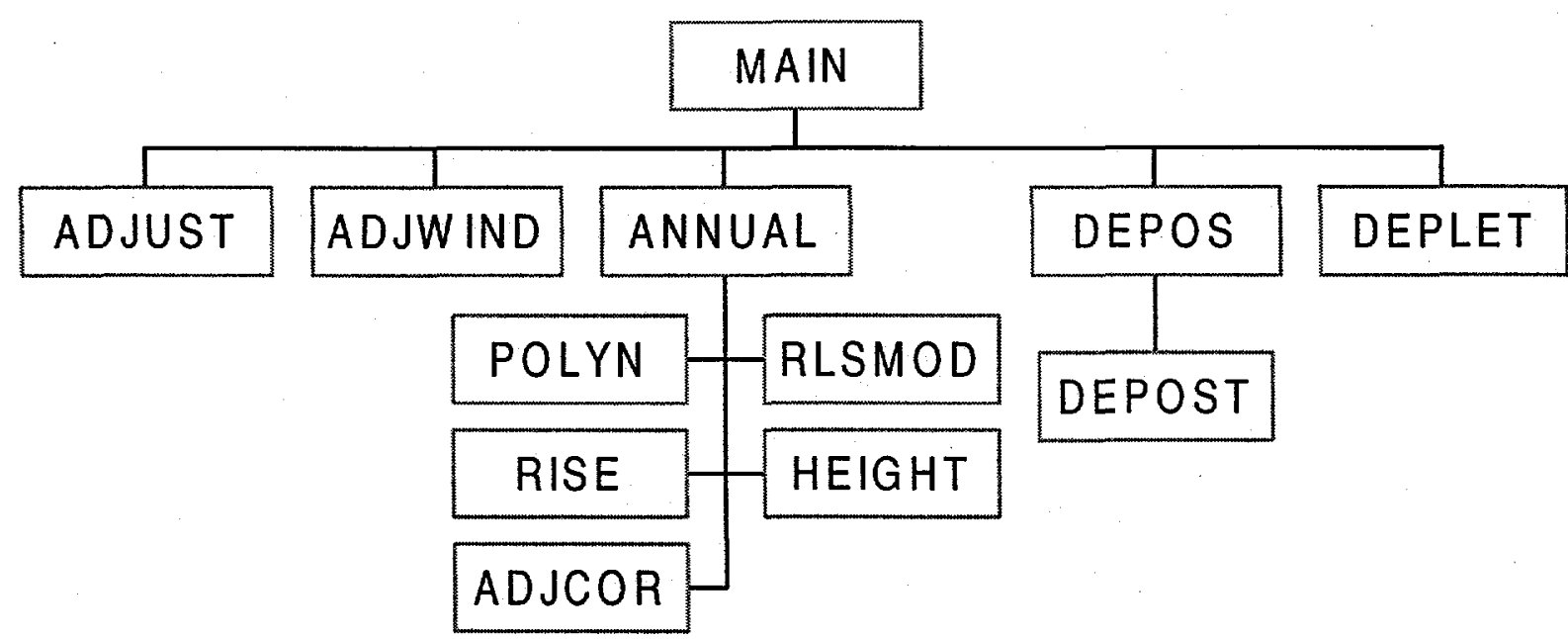

ADJWIND - Provides a wind speed correction factor, CORR, when the release height does not equal the height at which the wind speed is measured. The correction factor is defined below.

$$
\operatorname{CORR}=\left(\frac{\mathrm{SL}}{\mathrm{PL}}\right)^{\mathrm{Ex}}
$$

where

SL desired wind height, $\mathrm{m}$

PL measured wind height, $61 \mathrm{~m}$

EX $\quad 0.25$ (stability classes A, B, C, D)

0.50 (stability classes $\mathrm{E}, \mathrm{F}, \mathrm{G}$ )

ANNUAL - Calculates annual-average ground-level and elevated relative air concentrations $(\chi / \mathrm{Qs})$ and deposition concentrations (D/Qs) for a uniform distribution of effluent across the compass sector. For an elevated release, the $\chi / Q$ values are calculated as follows:

$$
\frac{\chi}{Q}(\mathrm{x}, \mathrm{k})=2.032 \sum_{\mathrm{ij}} \frac{\mathrm{JFD}_{\mathrm{ijk}} \operatorname{DEC}_{\mathrm{i}}(\mathrm{x}) \operatorname{DEPL}_{\mathrm{ij}}(\mathrm{x}, \mathrm{k})}{\mathrm{u}_{\mathrm{i}}(\mathrm{x}) \sigma_{\mathrm{z}_{\mathrm{j}}}(\mathrm{x}) \mathrm{x}} \mathrm{e}^{-0.5\left(\frac{\mathrm{h}_{\mathrm{e}}}{\sigma_{\mathrm{z}_{\mathrm{j}}}(\mathrm{x})}\right)^{2}}
$$


where

$\chi / \mathrm{Q}(\mathrm{x}, \mathrm{k}) \quad$ relative air concentration at $\mathrm{x}$ meters in the $\mathrm{kth} 22.5$ degree compass sector, $\mathrm{s} / \mathrm{m}^{3}$

i

wind speed class (1-6) corresponding to the ranges shown in Table 1

j atmospheric stability class (1-7) corresponding to Pasqill-Gifford stability classes A-G
A, B, C
Unstable
$\mathrm{D}$ Neutral
E, F, G
Stable

$\mathrm{u}_{\mathrm{i}}(\mathrm{x}) \quad$ midpoint of the ith wind speed class (see table below), $\mathrm{m} / \mathrm{s}$

$\sigma_{\mathrm{zj}}(\mathrm{x}) \quad$ vertical plume spread due to ambient free-stream turbulence as determined by subroutine POLYN, m

$\mathrm{JFD}_{\mathrm{ijk}} \quad$ joint frequency distribution of wind speed and atmospheric stability observations - percent of time over five year period that stability class $j$ and wind speed range $\mathrm{i}$ occur in sector $\mathrm{k}$

$\operatorname{DEPL}_{\mathrm{ij}}(\mathrm{x}, \mathrm{k}) \quad$ plume depletion factor as determined by subroutine DEPLET
$\mathrm{h}_{\mathrm{e}}$
effective plume height as defined by subroutines RISE and HEIGHT, m
$\operatorname{DEC}_{\mathrm{i}}(\mathrm{x}) \quad$ radioactive decay, $\mathrm{e}^{-(0.693 \mathrm{tT})}$
t
travel time $=\mathrm{x} /\left(86400 * \mathrm{u}_{\mathrm{i}}\right)$, days
T
half-life of the radioactive material, days
$\mathbf{x}$
downwind or travel distance, meters

Table 1. Wind speed classes and ranges.

\begin{tabular}{|c|c|c|}
\hline Wind Speed Class & $\begin{array}{c}\text { Wind Speed Range } \\
(\mathbf{m} / \mathbf{s})\end{array}$ & $\begin{array}{c}\text { Wind Speed Range } \\
\text { Midpoint }-\mathbf{u}(\mathbf{m} / \mathbf{s})\end{array}$ \\
\hline 1 & $0 \leq \mathrm{u} \leq 2$ & 1.0 \\
2 & $2<\mathrm{u} \leq 4$ & 3.0 \\
3 & $4<\mathrm{u} \leq 6$ & 5.0 \\
4 & $6<\mathrm{u} \leq 8$ & 7.0 \\
5 & $8<\mathrm{u} \leq 12$ & 9.0 \\
6 & $12<\mathrm{u} \leq 14.1$ & 13.05 \\
\hline
\end{tabular}


For the ground-level releases, the larger value from the following two equations is used for specific downwind locations.

$$
\begin{aligned}
& \frac{\chi}{Q}(\mathrm{x}, \mathrm{k})=2.032 \sum_{\mathrm{ijk}} \frac{\mathrm{JFD}_{\mathrm{ijk}} \mathrm{DEC}_{\mathrm{i}}(\mathrm{x}) \mathrm{DEPL}_{\mathrm{ij}}(\mathrm{x}, \mathrm{k})}{\mathrm{u}_{\mathrm{i}}(\mathrm{x}) \sqrt{3} \sigma_{\mathrm{zj}}(\mathrm{x})} \\
& \frac{\chi}{\mathrm{Q}}(\mathrm{x}, \mathrm{k})=2.032 \sum_{\mathrm{ijk}} \frac{\mathrm{JFD}_{\mathrm{ijk}} \mathrm{DEC}(\mathrm{x}) \mathrm{DEPL}_{\mathrm{ij}}(\mathrm{x}, \mathrm{k})}{\mathrm{u}_{\mathrm{i}}(\mathrm{x}) \sqrt{\sigma_{z \mathrm{j}}^{2}(\mathrm{x})+\mathrm{cD}^{2} / \pi}}
\end{aligned}
$$

where

c defined constant, 0.5

$\mathrm{D}$ building height used to evaluate dispersion due to building wake effects

Subroutine ANNUAL also calculates relative concentrations and deposition for ten downwind segments in each of the 16 compass sectors which is used in the population dose calculations. The computed value represents an average value for the downwind directional sector bounded by the range of the region. The method used by ANNUAL to calculate a segment average $\chi / \mathrm{Q}$ is shown in Equation 5. A similar equation is also used to calculate segment average $\mathrm{D} / \mathrm{Qs}$.

$$
\frac{\bar{\chi}}{Q} \operatorname{seg}(k)=\frac{R_{1} \frac{\chi}{Q}\left(R_{1}, k\right)+R_{2} \frac{\chi}{Q}\left(R_{2}, k\right)+R_{3} \frac{\chi}{Q}\left(R_{3}, k\right)}{R_{1}+R_{2}+R_{3}}
$$

where

$\frac{\bar{\chi}}{\mathrm{Q}} \operatorname{seg}(\mathrm{k}) \quad$ average $\chi / \mathrm{Q}$ for the segment in compass sector $\mathrm{k}$

$\frac{\bar{\chi}}{\mathrm{Q}}\left(\mathrm{R}_{\mathrm{n}}, \mathrm{k}\right) \quad \chi / \mathrm{Q}$ at downwind distance $\mathrm{R}_{\mathrm{n}}$ for compass sector $\mathrm{k}$

$R_{1} \quad$ downwind distance of the segment boundaries

DEPOS - This subroutine calculates D/Qs (relative deposition per unit area). DEPOS uses the same distance information as ANNUAL. 


$$
\frac{D}{Q}(x, k)=\frac{R F(x, k) \sum_{i j} D_{i j} f_{i j}(k)}{(2 \pi / 16) x}
$$

$$
\begin{array}{ll}
\frac{\mathrm{D}}{\mathrm{Q}}(\mathrm{x}, \mathrm{k}) & \begin{array}{l}
\text { average relative deposition per unit area at a downwind distance } \mathrm{x} \text { and } \\
\text { direction } \mathrm{k}, \mathrm{m}^{-2}
\end{array} \\
\mathrm{D}_{\mathrm{ij}} & \begin{array}{l}
\text { relative deposition rate from Figures } 7 \text { through } 10 \text { of the USNRC Regulatory } \\
\text { Guide } 1.111 \text { for the ith wind speed class and the jth stability class, } \mathrm{m}^{-1}
\end{array} \\
\mathrm{f}_{\mathrm{ij}}(\mathrm{k}) & \begin{array}{l}
\text { joint probability of the ith wind speed class, } \mathrm{jth} \text { stability class, and } \mathrm{kth} \text { wind } \\
\text { direction sector }
\end{array} \\
\mathrm{x} & \begin{array}{l}
\text { downwind distance, } \mathrm{m} \\
\mathrm{RF}(\mathrm{x}, \mathrm{k}) \quad \begin{array}{l}
\text { correction factor for air recirculation and stagnation at distance } \mathrm{x} \text { and } \mathrm{kth} \text { wind } \\
\text { direction }
\end{array}
\end{array}
\end{array}
$$

DEPOST - Solves the polynomial regression equations for the deposition curves of USNRC Regulatory Guide 1.111 in order to define a value to $D_{i j}$ defined above.

POLYN - This subroutine calculates values of vertical and horizontal plume spread as a function of downwind distance. Vertical plume spread is calculated using the following equation:

\begin{tabular}{|c|c|c|c|c|c|c|c|c|c|}
\hline \multirow{3}{*}{$\begin{array}{l}\text { Pasquill } \\
\text { Category }\end{array}$} & \multicolumn{9}{|c|}{ Valid Range (m) } \\
\hline & \multicolumn{3}{|c|}{$<100 \mathrm{~m}$} & \multicolumn{3}{|c|}{$100-1000 \mathrm{~m}$} & \multicolumn{3}{|c|}{$>1000 \mathrm{~m}$} \\
\hline & $\mathbf{a}$ & b & c & $\mathbf{a}$ & b & c & $\mathbf{a}$ & $\mathbf{b}$ & $\mathbf{c}$ \\
\hline $\bar{A}$ & 0.192 & 0.936 & 0 & 0.00066 & 1.941 & 9.27 & 0.00024 & 2.094 & -9.6 \\
\hline B & 0.156 & 0.922 & 0 & 0.0382 & 1.149 & 3.3 & 0.055 & 1.098 & 2.0 \\
\hline $\mathrm{C}$ & 0.116 & 0.905 & 0 & 0.113 & 0.911 & 0.0 & 0.113 & 0.911 & 0.0 \\
\hline $\mathrm{D}$ & 0.079 & 0.881 & 0 & 0.222 & 0.725 & -1.7 & 1.26 & 0.516 & -13 \\
\hline $\mathrm{E}$ & 0.063 & 0.871 & 0 & 0.211 & 0.678 & -1.3 & 6.73 & 0.305 & -34 \\
\hline $\mathrm{F}$ & 0.053 & 0.814 & 0 & 0.086 & 0.74 & -.035 & 18.05 & 0.18 & -48.6 \\
\hline
\end{tabular}

$$
\sigma_{z_{j}}(x)=a x^{b}+c
$$

where
$\mathrm{a}, \mathrm{b}, \mathrm{c}$
coefficients, derived by Eimutis and Konicek (1972), which are functions of stability class and distance - values are shown in Table 2.
$x$
downwind distance, $\mathrm{m}$

Table 2. Values used to Calculate Vertical Diffusion Coefficients (see Eq 7) 
The horizontal plume spread is calculated using the following equation

$$
\sigma_{y_{j}}(x)=\mathrm{Ax}^{0.9031}
$$

where $A$ is represented by the values that are shown in Table 3 as a function of Pasquill's atmospheric stability categories and $\mathrm{x}$ is the downwind distance in meters.

Table 3. Values of A for Horizontal Diffusion Coefficients

\begin{tabular}{|c|c|}
\hline Pasquill Category & A \\
\hline A & 0.3658 \\
B & 0.2751 \\
C & 0.2089 \\
D & 0.1471 \\
E & 0.1046 \\
F & 0.0722 \\
\hline
\end{tabular}

The vertical and horizontal diffusion coefficients for stability class $\mathrm{G}$ are determined using the following equation:

$$
\sigma_{\mathrm{Z}}(\mathrm{G})=2 \mathrm{Alog} 10(\mathrm{~F})-\mathrm{Alog} 10(\mathrm{E})
$$

where $\mathrm{E}$ and $\mathrm{F}$ are the horizontal diffusion coefficient values for stability classes $\mathrm{E}$ and $\mathrm{F}$, respectively.

RLSMOD - Invoked for mixed-mode releases. RLSMOD evaluates the need for an entrainment factor, E, by computing the ratio of the plume exit velocity to the wind speed. If a mixed-mode release is indicated, the proportion of the plume considered to be elevated and the proportion considered to be ground level are determined by the following relationships:

$\mathrm{E}_{\mathrm{t}}=1.0$

for $w / u<1.0$

$\mathrm{E}_{\mathrm{t}}=2.58-1.58(\mathrm{w} / \mathrm{u})$

for $1.0 \leq \mathrm{w} / \mathrm{u} \leq 1.5$

$\mathrm{E}_{\mathrm{t}}=0.3-0.06(\mathrm{w} / \mathrm{u})$

for $1.5<\mathrm{w} / \mathrm{u}<5.0$

$\mathrm{E}_{\mathrm{t}}=0.0$

for $w / u \geq 5.0$

where

$\mathrm{E}_{\mathrm{t}} \quad$ fraction of the time the release is ground level

w plume exit velocity, $\mathrm{m} / \mathrm{s}$

u

average wind speed at vent height, $\mathrm{m} / \mathrm{s}$ 
RISE - Plume rise, $h_{p r}$, is calculated using the formula of Briggs (1979). Plume rise due to momentum and buoyancy is considered. At SRS, atmospheric releases are considered to be ambient temperature plumes, and therefore, plume rise may be considered to be exclusively a function of momentum.

The formulae of Briggs are based on the effective stack height method in which plume rise is artificially decoupled from dispersion. The principal site-specific parameters upon which plume rise depends are effluent exit velocity, wind speed, stack diameter, and stack height. The specific empirical relationships recognized by RISE for $h_{\mathrm{pr}}$ as a function of momentum are:

For stability classes A, B, C, D, the smaller value from the following two equations is used:

$$
\begin{gathered}
\mathrm{h}_{\mathrm{pr}}=1.44\left(\frac{\mathrm{w}}{\mathrm{u}}\right)^{2 / 3}\left(\frac{\mathrm{x}}{\mathrm{d}}\right)^{1 / 3} \mathrm{~d} \\
\mathrm{~h}_{\mathrm{pr}}=3\left(\frac{\mathrm{w} \cdot \mathrm{d}}{\mathrm{u}}\right)
\end{gathered}
$$

where

w effluent exit velocity, $\mathrm{m} / \mathrm{s}$

$\mathrm{u} \quad$ wind speed at release height, $\mathrm{m} / \mathrm{s}$

$\mathrm{x} \quad$ downwind distance, $\mathrm{m}$

d stack diameter, $\mathrm{m}$

If the effluent velocity is less than $1.5 *$ wind speed, then plume rise height is further corrected as follows

$$
h_{p r}=h_{p r}-3(1.5-w / u) \bullet d
$$

For stability classes E, F, G, the smallest value from the following equations is used:

$$
\begin{gathered}
h_{p r}=1.44\left(\frac{w}{u}\right)^{2 / 3}\left(\frac{x}{d}\right)^{1 / 3} d \\
h_{p r}=3\left(\frac{w \bullet d}{u}\right)
\end{gathered}
$$




$$
\begin{gathered}
\mathrm{h}_{\mathrm{pr}}=4\left(\frac{\mathrm{F}_{\mathrm{m}}}{\mathrm{s}}\right)^{0.25} \\
\mathrm{~h}_{\mathrm{pr}}=1.5\left(\frac{\mathrm{F}_{\mathrm{m}}}{\mathrm{u}}\right)^{1 / 3} \mathrm{~s}^{-1 / 6}
\end{gathered}
$$

where $F_{m}$ is the momentum flux parameter, $\mathrm{m}^{4} / \mathrm{s}^{2}$

$$
\mathrm{F}_{\mathrm{m}}=\left(\frac{\mathrm{w} \cdot \mathrm{d}}{2}\right)^{2}
$$

s acceleration per unit vertical displacement for adiabatic motion in the atmosphere, by stability class - see below, $\mathrm{s}^{-2}$

$\begin{array}{ll}\mathrm{E} & 8.75 \mathrm{E}-04 \mathrm{~s}^{-2} \\ \mathrm{~F} & 1.75 \mathrm{E}-03 \mathrm{~s}^{-2} \\ \mathrm{G} & 2.45 \mathrm{E}-03 \mathrm{~s}^{-2}\end{array}$

If the effluent velocity is less than $1.5^{*}$ wind speed, then plume rise height is further corrected as follows

$$
\mathrm{h}_{\mathrm{pr}}=\mathrm{h}_{\mathrm{pr}}-3(1.5-\mathrm{w} / \mathrm{u}) \cdot \mathrm{d}
$$

HEIGHT - An effective plume height, $h_{e}$ is calculated by XOQDOQ using Equation 19. HEIGHT linearly interpolates an $h_{t}$ for a given downwind distance $x$, based on the highest elevation between the source and the given downwind distance.

$$
h_{e}=h_{s}+h_{p r}-h_{t} \quad\left(h_{e} \geq 0\right)
$$

$h_{e} \quad$ effective plume height, $m$

$\mathrm{h}_{\mathrm{s}} \quad$ physical stack height, $\mathrm{m}$

$\mathrm{h}_{\mathrm{pr}} \quad$ plume rise, $\mathrm{m}$

$h_{t} \quad$ terrain height, $m$

ADJCOR - Keeps track of the cross-over heights (discussed in next section) which each plume passes for each direction, wind-speed class, and stability category. This subroutine determines which depletion and deposition adjustment factors derived in ADJUST should be used. XOQDOQ's treatment of depletion and depositions are described more fully in a subsection below. 


\subsubsection{Depletion}

Plume depletion by XOQDOQ is automatic whenever 8-day decayed $\chi / Q$ s are calculated. Plume depletion via ground surface absorption is assumed by Markee (1967) to be a function of eddy diffusivity and wind velocity. By establishing vertical profiles of these variables, Markee was able to estimate vertical plume concentration profiles for a variety of release conditions. The results of studies were used by the USNRC to develop depletion factors for general use. Depletion curves for release heights of $0,30,60$, and 100 meters, expressed as a function of atmospheric stability class were published in the USNRC Regulatory Guide 1.111 .

XOQDOQ decreases the total mass in the plume at progressive downwind distances by solving the polynomial regression equations of the depletion curves described above. Because depletion factors are a function of plume height, XOQDOQ uses subroutines ADJCOR and ADJUST to track the plume and modify the depletion factors as terrain features (and therefore, effective plume heights) change with increasing distance. This often dictates that more than one set of depletion curves be used. The downwind distances at which it is necessary to change from one set of curves to another are referred to in XOQDOQ as cross-over points.

XOQDOQ's treatment of depletion is shown in Figure 3 for a $60-\mathrm{m}$ release. The depletion factors of USNRC Regulatory Guide 1.111 would be adjusted by XOQDOQ as shown in Figure 3.

\subsubsection{Deposition}

Relative deposition is calculated in XOQDOQ based on deposition velocities $\left(v_{d}\right)$ measured by Pelletier and Zimbrick as a function of wind speed. The data collected are specific to the vegetation, wind velocity, temperature, and humidity profiles of the northwest desert.

The deposition curves developed by the USNRC from the Pelletier and Zimbrick data have not shown to be equally applicable to all sites. Also, the USNRC position does not address the roles of such parameters as particle size distribution, solubility, roughness length for particulates or surface area, surface moisture, and stoma openings for gases. However, to follow USNRC Guidance these curves are used.

XOQDOQ uses the deposition curves of the USNRC Regulatory Guide 1.111 to determine relative deposition rates. Deposition rates are considered to be functions of the distance from the source, release height and atmospheric stability. XOQDOQ estimates relative deposition per unit area by multiplying the relative deposition rate by the fraction of the release transported into the sector. This value must then be divided by the arc length of the sector at the distance of interest.

As required for the depletion factors, XOQDOQ makes adjustments in the deposition factors to account for changes in plume height. The adjustments made at the cross-over points can be categorized by looking at Figure 3 . 
Figure 3. XOQDOQ Treatment of Cross-Over Points

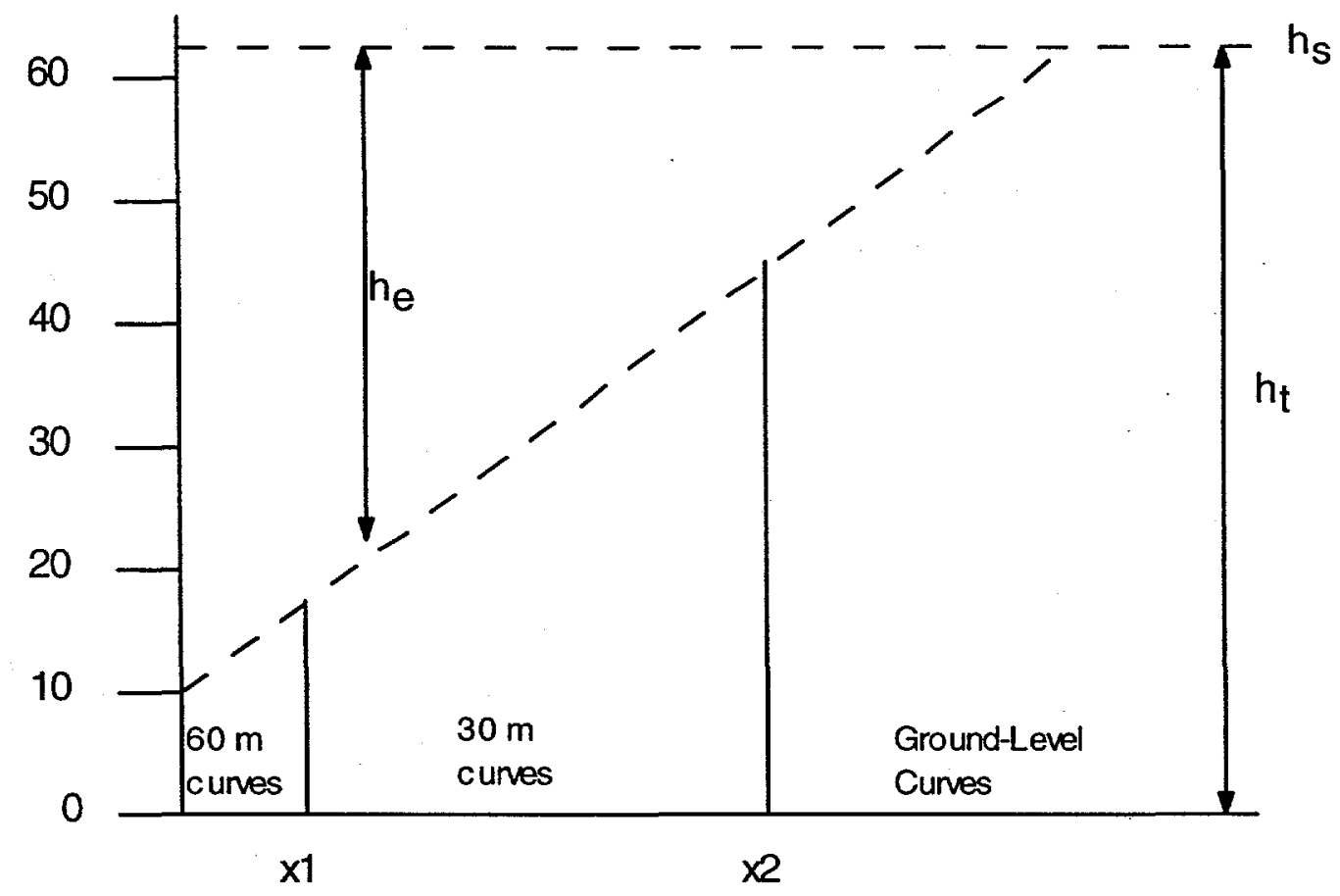

$\mathrm{X}<\mathrm{x}_{1} \quad$ Stability-class-specific depletion factors taken from their respective $60-\mathrm{m}$ curves. No adjustment necessary.

$\mathrm{x}_{1} \leq \mathrm{X} \leq \mathrm{x}_{2} \quad$ Once the plume passes a cross-over point, depletion factor adjustments are required. Depletion factors for distances in this range are adjusted by adding to them the difference between the $60-\mathrm{m}$ and $30-\mathrm{m}$ depletion factors evaluated at the cross-over point, $x_{1}$.

$\mathrm{X} \geq \mathrm{x}_{2}$ At this point, the depletion factors are adjusted by adding to them the difference in the 60 - and 30- $m$ curves at $x_{1}$ as well as the difference between the 30-m and ground-level curves at $x_{2}$.

\subsubsection{XOQDOQResults}

The results of the subprogram XOQDOQ include the following for each sector and radial distance:

$\frac{\chi}{Q}$ - relative air concentration $\left(\mathrm{s} / \mathrm{m}^{3}\right)$ 
$\left(\frac{\chi}{Q}\right)_{D}$ - relative air concentration decayed by 2.26 days $\left(\mathrm{s} / \mathrm{m}^{3}\right)$. This is a holdover from US

Nuclear Regulatory Guide 1.111 when all noble gases were conservatively assumed to have a half life of 2.26 days.

$\left(\frac{\chi}{Q}\right)_{D D}$ - relative air concentration decayed for 8.0 days and corrected for depletion using the curves discussed above $\left(\mathrm{s} / \mathrm{m}^{3}\right)$. This is a holdover from US Nuclear Regultory Guide 1.111 when all radioiodines were assumed to have a half life of 8.0 days. When this concentration is used in conjunction with the real half life of the radionuclide, the 8.0 day decay is removed.

\subsection{GASPAR}

The GASPAR code (Eckerman et. al. 1980) was written in 1977 by Oak Ridge National Laboratory for the USNRC. The models in GASPAR calculate atmospheric concentrations, deposition rates, concentrations in foodstuffs, and radiation dose to individuals and populations resulting from chronic releases of radionuclides to the atmosphere (USNRC 1977a). The atmospheric transport models that feed GASPAR are contained in XOQDOQ (USNRC 1977b, Sagendorf et. al. 1982).

\subsubsection{GASPAR Code Structure}

The GASPAR program diagram in Figure 4 shows the interactions between modules relative to data transfer for all of the main subroutines. GASPAR is arranged so that it operates in either MAXDOSE-SR or POPDOSE-SR to calculate radiation doses to humans resulting from atmospheric releases of radionuclides.

\subsubsection{Subroutine Descriptions}

BLKDAT - reads in various data that are needed for dose calculations - most of which is element specific (i.e. stable element transfer factors for milk and meat).

REDDF -reads in dose factor libraries. Dose factors are based on DOE/EH-0070 and DOE/EH-0071 (USDOE 1988a and 1988b), which are for external and internal exposure, respectively. For external exposure, values are also taken from Hamby (1991b and 1991c) which includes daughter products that are in equilibrium with the parent.

REDSIT- used to read in array data for meat, milk, and agricultural productivity that could be used for population runs.

PRINTM - prints meteorological and site data.

AGPROD - calculates agricultural productivities for a fifty-mile array. 
Figure 4. GASPAR Code Layout

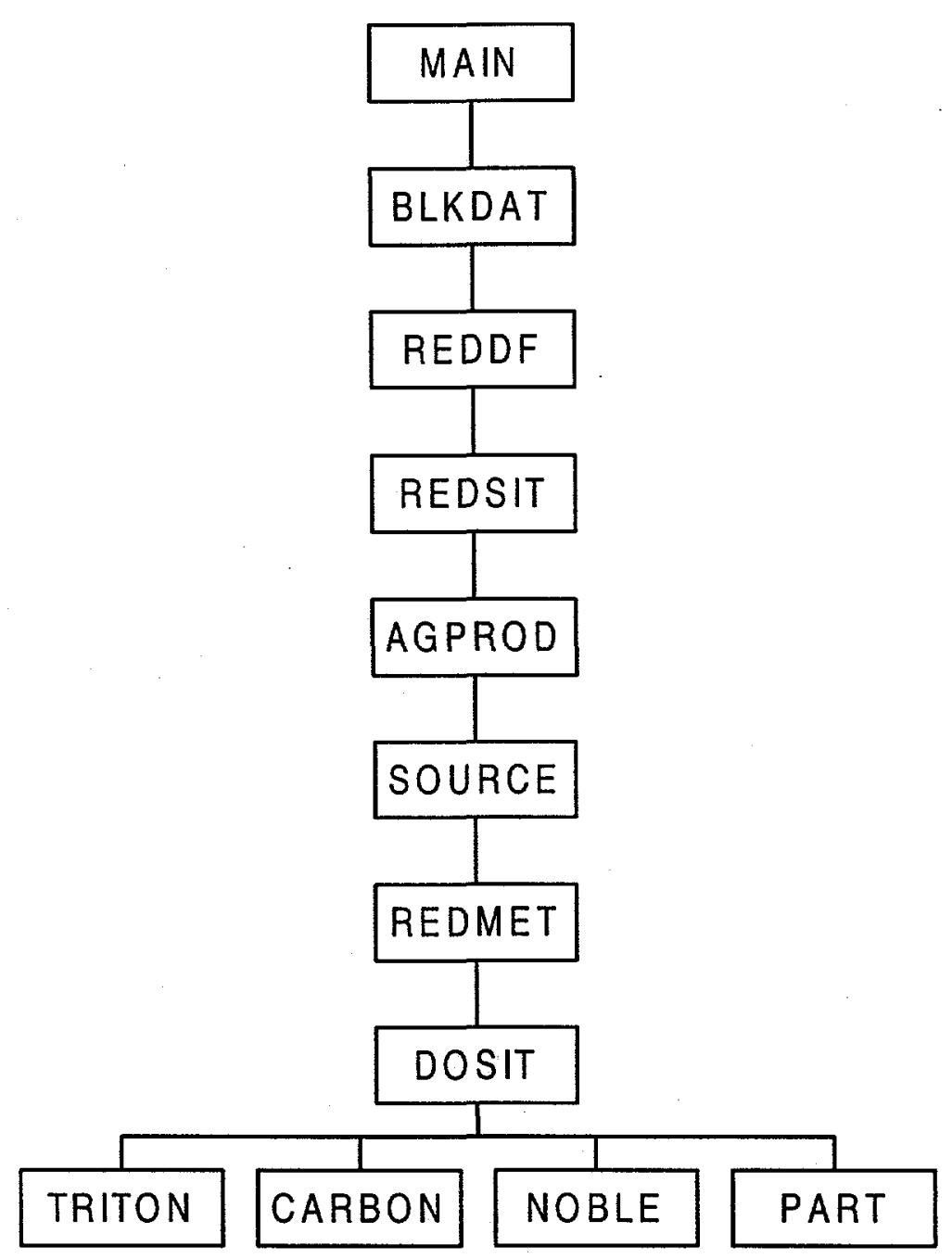

SOURCE - checks source term to ensure dose factor is available for all radionuclides that are included.

REDMET- reads in meteorological data, relative air concentrations, and deposition rates as calculated by XOQDOQ.

DOSIT - subroutine where the bulk of the calculations are performed. Calls the following subroutines that calculate dose based on which radionuclide is being considered.

TRITON - calculates tritium dose.

CARBON - calculates carbon dose.

NOBLE - calculates dose from noble gases. 
PART - calculates dose from particulates.

Following the dose calculations there are a series of subroutines that store the output.

\subsubsection{GASPAR Methodology}

For radionuclide transport at the SRS, actual radioactive decay is calculated for each nuclide released to the atmosphere. GASPAR accepts only four outputs from the XOQDOQ computer code: 1 ) relative air concentration, $\chi / Q ; 2)$ relative air concentration decayed by 2.26 days, $\left.\chi_{\mathrm{D}} / \mathrm{Q} ; 3\right)$ relative air concentration decayed and depleted for 8 days, $\chi_{\mathrm{DD}} / \mathrm{Q}$; and 4 ) relative deposition, $\mathrm{D} / \mathrm{Q}$. The nondecayed $\chi / \mathrm{Q}$ and the 2.26 day decayed $\chi_{\mathrm{D}} / \mathrm{Q}$ are used to calculate the travel time from the source to the receptor (see section on deposition).

\subsubsection{Nuclide Concentrations In The Atmosphere}

\subsubsection{Tritium and Carbon-14}

Downwind atmospheric concentrations, $\chi_{i}$, of tritium and carbon-14 are estimated using

$$
\chi_{\mathrm{i}}=\frac{\chi}{\mathrm{Q}} \cdot \mathrm{Q}_{\mathrm{i}} \cdot 10^{6} \cdot 3.17 \times 10^{-8} \frac{\mathrm{yr}}{\mathrm{s}}
$$

where

$\chi_{i} \quad$ air concentration, $\mu \mathrm{Ci} / \mathrm{m}^{3}$

$\mathrm{Q}_{\mathrm{i}} \quad$ release amount by radionuclide, $\mathrm{Ci} / \mathrm{yr}$

Since both tritium and carbon-14 have relatively long half-lives, radiological decay is not taken into account when estimating downwind concentration for these nuclides.

\subsubsection{Noble Gases}

Air concentrations of noble gases are estimated by,

$$
\chi_{i}=\frac{\chi}{Q} \cdot Q_{i} \cdot 10^{6} \cdot 3.17 \times 10^{-8} \frac{y r}{s} \bullet \mathrm{e}^{-\lambda_{\mathrm{t}} \mathrm{t}}
$$

where the exponential accounts for radioactive decay during transit to the receptor. The value of $t$ is determined in the same manner as for the calculation of deposition rate.

\subsubsection{Radioiodines}

Radioiodine concentrations in the atmosphere are determined using, 


$$
\chi_{\mathrm{i}}=\left\{\frac{\chi}{\mathrm{Q}} \cdot\left(1-\mathrm{F}_{\mathrm{I}}\right)+\frac{\chi_{\mathrm{DD}}}{\mathrm{Q}} \cdot \mathrm{F}_{\mathrm{I}} \cdot \mathrm{e}^{31.62 \mathrm{t}}\right\} \bullet \mathrm{Q}_{\mathrm{i}} \cdot \mathrm{e}^{-\lambda_{\mathrm{i}} \mathrm{t}}
$$

where

$\chi / Q \quad$ relative air concentration

$\chi_{\mathrm{DD}} / \mathrm{Q} \quad$ decayed and depleted concentration

$F_{I} \quad$ fraction of iodine that is elemental

The factor in brackets calculates a weighted relative air concentration accounting for the deposition of the elemental fraction. The positive rate coefficient (31.62) negates decay from the generic 8-day half life that was already applied to the $\chi / Q$ within XOQDOQ. An exponential term is also included in this equation to account for the actual radioactive decay during plume transit.

\subsubsection{Other Nuclides}

Air concentrations of the remaining nuclides (those not considered above), are calculated using,

$$
\chi_{\mathrm{i}}=\frac{\chi_{\mathrm{DD}}}{\mathrm{Q}} \cdot \mathrm{Q}_{\mathrm{i}} \cdot 10^{6} \cdot 3.17 \times 10^{-8} \frac{\mathrm{yr}}{\mathrm{s}} \bullet \mathrm{e}^{\left(31.62-\lambda_{\mathrm{t}}\right) \mathrm{t}}
$$

where all terms have been defined previously. Again, the positive rate coefficient in the exponential term (31.62 $\left.\mathrm{yr}^{-1}\right)$ negates the decay from the 8-day half life that was already applied to the $\chi / Q$ within XOQDOQ.

\subsubsection{Deposition}

Deposition of iodines and particulates can occur by several mechanisms. The primary removal mechanism of atmospheric material is gravitational settling or contact with the ground, vegetation, or other ground cover such as buildings (dry deposition). Wet deposition occurs whereby gases and particulates are removed from an atmospheric plume by precipitive scavenging (rain, sleet, snow). For long-term averages, such as those calculated in MAXDOSE-SR, dose calculations considering only dry deposition usually are not changed significantly by the consideration of wet deposition (USNRC 1977b). Wet deposition should be considered at sites that have a well-defined rainy season corresponding to the grazing season (USNRC 1977b).

Rainfall at the SRS averages 49 inches annually (from 1964 to 1999). Average monthly rainfall rates range between 2.5 and 5 inches per month. The SRS does not have a rainy season, however, the months of November and December typically have less rain than other months (Hunter 1990). Since there is not a well-defined rainy season, wet deposition would 
be insignificant at the SRS for long-term averages and, therefore, is not considered in MAXDOSE-SR.

Dry deposition of tritium, carbon-14 and the noble gases is not considered. Specific activity models for tritium and carbon-14 utilize atmospheric concentrations to estimate vegetation. concentrations.

\subsubsection{Radioiodine}

Deposition rates, $\mathrm{d}_{\mathrm{i}}$, of iodine radioisotopes are estimated using,

$$
\mathrm{d}_{\mathrm{i}}=\frac{\mathrm{D}}{\mathrm{Q}} \cdot \mathrm{Q}_{\mathrm{i}} \cdot \mathrm{F}_{\mathrm{I}} \cdot 10^{6} \cdot \mathrm{e}^{-\lambda_{\mathrm{i}} \mathrm{t}}
$$

where

$$
\begin{array}{ll}
\mathrm{D} / \mathrm{Q} & \text { relative deposition value, } 1 / \mathrm{m}^{2} \\
\mathrm{Q}_{\mathrm{i}} & \text { radionuclide release rate, } \mathrm{Ci} / \mathrm{yr} \\
\mathrm{F}_{\mathrm{I}} & \text { fraction of iodine assumed to be elemental, unitless } \\
\lambda_{\mathrm{i}} & \text { nuclide-specific decay constant, } \mathrm{yr}^{-1} \\
\mathrm{t} & \text { plume travel time from the source to the receptor, } \mathrm{yr}
\end{array}
$$

The parameter $t$ is the average time required for the effluent to reach the receptor (site boundary for maximum individual). The XOQDOQ program calculates a decayed and a nondecayed $\chi / \mathrm{Q}$. The decayed $\chi / \mathrm{Q}$ is obtained by assuming the effluent is radioactive with a half-life of 2.26 days (USNRC 1977b). The value of $t$ is found by solving the radioactive decay equation used in XOQDOQ to calculate a 2.26 day decayed relative air concentration,

$$
\frac{\chi_{\mathrm{D}}}{\mathrm{Q}}=\frac{\chi}{\mathrm{Q}} \mathrm{e}^{-\left(112 \mathrm{yr}^{-1}\right) \mathrm{t}}
$$

where the value $112 \mathrm{yr}^{-1}$ is the decay constant for a 2.26 day half-life. The plume travel time (in years) is then,

$$
\mathrm{t}=\frac{\ln \left(\frac{\chi_{\mathrm{D}} / \mathrm{Q}}{\chi / \mathrm{Q}}\right)}{\left(\frac{\ln 2 \cdot 365 \mathrm{~d}}{2.26 \mathrm{~d} \cdot 1 \mathrm{yr}}\right)}
$$

The plume travel time is used in subsequent equations to account for radioactive decay, ground deposition, and plume depletion. 


\subsubsection{Other Nuclides.}

Deposition rates for all remaining nuclides are determined using

$$
\mathrm{d}_{\mathrm{i}}=\frac{\mathrm{D}}{\mathrm{Q}} \bullet \mathrm{Q}_{\mathrm{i}} \bullet 10^{6} \bullet \mathrm{e}^{\left(31.62-\lambda_{\mathrm{i}}\right) \mathrm{t}}
$$

where all parameters have been previously defined. The deposition equilibrium coefficient for iodine ( $\left.31.62 \mathrm{yr}^{-1}\right)$ is applied to all other nuclides as well. Deposition is modeled for all radionuclides, except for tritium, carbon-14 and noble gases.

\subsubsection{Nuclide Concentration In Vegetation}

\subsubsection{Tritium}

A specific activity model describes the uptake of tritium in vegetation. Tritium concentrations in vegetation are determined directly from the concentrations of tritium in atmospheric moisture. Equilibrium is assumed to be achieved in a short time relative to an annual release. The concentration of tritium in vegetation, $\mathrm{C}_{\mathrm{T}}^{\mathrm{v}}$, is determined by

$$
\mathrm{C}_{\mathrm{T}}^{\mathrm{v}}=\frac{\chi_{\mathrm{T}} \cdot 0.75 \cdot 0.5}{\mathrm{H}}
$$

where

$\mathrm{C}_{\mathrm{T}}^{\mathrm{v}} \quad$ concentration in vegetation, $\mu \mathrm{Ci} / \mathrm{g}$

$\chi_{\mathrm{T}} \quad$ atmospheric concentration, $\mu \mathrm{Ci} / \mathrm{m}^{3}$

0.75 fraction of plant mass that is water

0.5 concentration ratio of plant tritium to atmospheric tritium

$\mathrm{H}$ annual average absolute humidity (11 $\mathrm{g} / \mathrm{m}^{3}$ for SRS) (Hamby 1990)

Studies (Bauer and Hamby 1993, Hamby 1993) have shown that dose estimates for the vegetation consumption pathway are sensitive to the parameters in this model. Therefore, a site-specific value was determined for the plant-tritium-to-atmospheric-tritium model (Hamby and Bauer 1994).

\subsubsection{Carbon 14}

The carbon-14 model for vegetation concentrations is similar to the tritium model. The following equation is used to estimate the concentration: 


$$
\mathrm{C}_{\mathrm{c}}^{\mathrm{v}}=\frac{\chi_{\mathrm{c}} \cdot \mathrm{F}_{\mathrm{t}} \cdot 0.11}{0.00016}
$$

where
$\chi_{\mathrm{c}}$
atmospheric concentration, $\mu \mathrm{Ci} / \mathrm{m}^{3}$
$\mathrm{F}_{\mathrm{t}}$
0.5 - ratio of the total annual release time to the total annual time during which photosynthesis occurs (taken to be $4380 \mathrm{hrs}$ )
0.11
fraction of total plant mass that is natural carbon
0.00016
concentration of natural carbon in the atmosphere

\subsubsection{Other Nuclides}

The concentration of other nuclides in vegetation is determined using

$$
C_{i}^{V}=d_{i} \cdot\left[\frac{r_{i}\left(1-e^{-\lambda_{i}^{w} t_{e}}\right)}{Y_{V} \lambda_{i}^{w}}+\frac{B_{i}^{v}\left(1-e^{-\lambda_{i} t_{b}}\right)}{P \bullet \lambda_{i}}\right] \bullet e^{-\lambda_{i} t_{b}}
$$

where

$\mathrm{d}_{\mathrm{i}} \quad$ deposition rate-determined earlier

$r_{i} \quad$ fraction of the nuclide deposited that remains on the surface of the plant

$\lambda_{i}{ }^{w} \quad$ represents both weathering and radioactive loses

$t_{e} \quad$ crop exposure time

$\mathrm{Y}_{\mathrm{v}} \quad$ crop productivity

$\mathrm{B}_{\mathrm{i}}^{\mathrm{v}} \quad$ element-specific soil/plant uptake ratio

$\lambda_{\mathrm{i}} \quad$ radioactive decay constant

$t_{b} \quad$ time over which the buildup of radionuclides occurs

P surface soil density

$t_{h} \quad$ hold-up time after harvest (allowing decay before consumption)

The two expressions in the brackets account for contamination via foliar deposition and root uptake, respectively. All particulate nuclides are assume to be fully retained on vegetation $(r=1)$ while only $20 \%$ of the iodines are retained $(r=0.2)$. The loss constant, $\lambda_{i}{ }^{w}$ accounts for 
losses through physical weathering (14 day half-life) and radioactive decay. Values of $Y_{v}, t_{e}$, and $t_{h}$ vary depending on the type of crop and whether the vegetation is for human consumption or is to be used as fodder (Hamby 1991a).

Concentrations in four types of vegetation are calculated in GASPAR. These four types along with their associated parameter values are given in Table 4. Noble gases are assumed not to concentrate or deposit on vegetation.

Table 4. Parameters for Vegetation Concentrations

\begin{tabular}{|l|l|l|l|l|}
\hline Parameter & $\begin{array}{l}\text { Other } \\
\text { Vegetables }\end{array}$ & $\begin{array}{l}\text { Leafy } \\
\text { Vegetables }\end{array}$ & $\begin{array}{l}\text { Pasture } \\
\text { Grass }\end{array}$ & $\begin{array}{l}\text { Stored } \\
\text { Feed }\end{array}$ \\
\hline $\mathrm{r}$ (iodines) & 0.2 & same & same & same \\
$\mathrm{r}$ (particulates) & 1.0 & same & same & same \\
$\lambda_{\mathrm{w}}\left(\mathrm{yr} \mathrm{r}^{-1}\right)$ & $18.07+\lambda_{\mathrm{i}}$ & same & same & same \\
$\mathrm{t}_{\mathrm{e}}(\mathrm{yr})$ & 0.192 & 0.192 & 0.0822 & 0.192 \\
$\mathrm{Y}_{\mathrm{v}}\left(\mathrm{kg} / \mathrm{m}^{2}\right)$ & 0.7 & 0.7 & 1.8 & 0.7 \\
$\mathrm{~B}_{\mathrm{i}}$ & element specific & same & same & same \\
$\lambda_{\mathrm{l}}\left(\mathrm{yr} \mathrm{r}^{-1}\right)$ & nuclide specific & same & same & same \\
$\mathrm{t}_{\mathrm{b}}(\mathrm{yr})$ & scenario specific & same & same & same \\
$\mathrm{P}\left(\mathrm{kg} / \mathrm{m}^{2}\right)$ & 240 & same & same & same \\
$\mathrm{t}_{\mathrm{h}}(\mathrm{yr})$ & 0.164 & 0.00274 & 0 & 0.247 \\
$\mathrm{~d}_{\mathrm{i}}\left(\mathrm{mCi} / \mathrm{m}^{3} \mathrm{yr}\right.$ & nuclide specific & same & same & same \\
\hline
\end{tabular}

\subsubsection{Nuclide Concentrations In Meat And Milk}

Concentrations of radionuclides in meat and milk are determined from feed concentrations, fodder intake rates, and element-specific feed-to-meat/feed-to-milk transfer factors. The equations for meat and milk concentrations estimates are essentially identical with the exception of feed transfer coefficient. Concentrations are estimated using,

$$
\begin{aligned}
& C_{i}^{\text {meat }}=C_{i}^{\text {fodder }} \cdot F_{i}^{b} \cdot Q_{F} \cdot \mathrm{e}^{-\lambda_{i} t_{e}} \\
& C_{i}^{\text {milk }}=C_{i}^{\text {fodder }} \cdot F_{i}^{m} \cdot Q_{F} \cdot e^{-\lambda_{i} t_{f}}
\end{aligned}
$$

where

$$
\begin{array}{ll}
\mathrm{C}_{\mathrm{i}}^{\text {fodder }} & \text { nuclide concentration in cattle feed (determined below) } \\
\mathrm{F}_{\mathrm{i}}^{\mathrm{b}} \text { and } \mathrm{F}_{\mathrm{i}}^{\mathrm{m}} & \text { feed transfer coefficients for beef cow and milk cow, respectively } \\
\mathrm{Q}_{\mathrm{F}} & \text { cattle feed rate } \\
\mathrm{t}_{\mathrm{s}} \text { and } \mathrm{t}_{\mathrm{f}} & \text { transport time for meat and milk, respectively } \\
\text { Values for these parameters are listed in Table } 5 .
\end{array}
$$


Table 5. Parameters in GASPAR for Meat and Milk Ingestion Dose Calculations

\begin{tabular}{|l|c|c|c|}
\hline Parameter & Meat & Milk (cow) & Milk (goat) \\
\hline Feed consumption rated (kg/d) & 44 & 44 & 6 \\
Milking/Slaughter to consumption (d) & 6 & 2 & 2 \\
Fraction of year on pasture & 1.00 & 1.00 & 0.79 \\
Fraction intake from pasture* & 0.75 & 0.56 & 0.85 \\
\hline
\end{tabular}

*while on pasture

The nuclide concentration in fodder is estimated based on the fraction of time cattle spend on pasture and the fraction of that time that is spent consuming fresh pasture grass. The following equation calculates fodder concentration by weighting the concentration of pasture grass and stored feed.

$$
C_{i}^{\text {fodder }}=f_{p} f_{s} C_{i}^{p}+\left[f_{p}\left(1-f_{s}\right)+\left(1-f_{p}\right) C_{i}^{s}\right.
$$

$\mathrm{C}_{\mathrm{i}}^{\mathrm{p}} \quad$ concentration in pasture grass

$\mathrm{C}_{\mathrm{i}}^{\mathrm{s}} \quad$ concentration in stored feed

$f_{p} \quad$ fraction of time cattle spend on pasture

$f_{s} \quad$ fraction of time that cattle eat fresh grass while on pasture

Concentrations of nuclides in goat's milk are determined in the same manner as cow's milk and beef except using different values (see Table 5) for feed consumption rate and the fraction of time spent on pasture and eating pasture grass.

\subsubsection{Shine Dose}

\subsubsection{Plume Shine}

Dose to offsite individuals from plume shine is estimated in GASPAR only for noble gases. The gamma dose from a particular noble gas in the atmospheric plume is calculated by

$$
\mathrm{D}_{\mathrm{i}}^{\mathrm{p}}=\chi_{\mathrm{i}} \cdot \mathrm{SF} \cdot \mathrm{DF}_{\mathrm{i}}^{\mathrm{p}} \cdot 1 \mathrm{yr}
$$

where

$\chi_{\mathbf{i}} \quad$ atmospheric concentration

SF shielding factor accounting for the fraction of time spent indoors $(0.7$ for individuals)

$\mathrm{DF}_{\mathrm{i}}^{\mathrm{p}} \quad$ nuclide specific plume-shine dose factor, $\mathrm{mrem} \mathrm{m}^{3} / \mathrm{yr} \mu \mathrm{Ci}$ 


\subsubsection{Ground-Shine}

Ground-shine doses are calculated for all particulate, gamma emitting nuclides. The dose accounts for buildup over the plant lifetime and is given by,

$$
D_{i}^{g}=d_{i} \cdot S F \bullet D F_{i}^{g} \bullet \frac{1-e^{-\lambda_{i} t_{b}}}{\lambda_{i}} \bullet 1 y r
$$

where

$\mathrm{DF}_{\mathrm{j}}^{\mathrm{g}} \quad$ nuclide-specific ground-shine dose factor

All other terms are previously defined. The exponential term accounts for the ground-surface buildup and subsequent radiological decay. Nuclide specific doses are summed for the total dose.

\subsubsection{Inhalation Dose}

Inhalation dose is determined for the maximum individual and the population assuming a constant breathing rate and a constant concentration throughout the year of exposure. The nuclide-specific dose is estimated by,

$$
\mathrm{D}_{\mathrm{h}}^{\mathrm{inh}}=\chi_{\mathrm{i}} \cdot \mathrm{BR} \cdot \mathrm{DF}_{\mathrm{i}}^{\mathrm{inh}} \cdot 1000\left[\frac{\mathrm{mrem}}{\mathrm{rem}}\right] \cdot 1 \mathrm{yr}
$$

where

$\chi_{\mathrm{i}} \quad$ atmospheric concentration

BR breathing rate, $8000 \mathrm{~m}^{3} / \mathrm{yr}$ (USNRC 1977a)

$\mathrm{DF}_{\mathrm{i}}^{\text {inh }} \quad$ nuclide specific dose conversion factor, $\mathrm{rem} / \mu \mathrm{Ci}$

\subsubsection{Food Ingestion Dose}

Dose to the maximally exposed individual is estimated for ingestion of foodstuffs including vegetables, meat, and milk. Radionuclide intakes through the vegetation consumption pathway considers vegetables as being classified as either "leafy" or "other." The "other" category includes fruits, grains, produce, and below ground vegetables. The dose via vegetable consumption for a one year period is calculated using,

$$
D_{i}^{\text {veg }}=\left[C_{i}^{v} U^{v} f_{v}+C_{i}^{1} U^{l} f_{1}\right] \cdot D F_{i}^{i n g} \bullet 1000 \frac{\text { mrem }}{\text { rem }} \bullet 1 y r
$$

where 
$\mathrm{C}_{\mathrm{i}} \quad$ radionuclide concentrations in leafy or other vegetables

U consumption rates of the two vegetable classifications (see Table 6)

f fraction of two vegetable classifications that are home grown

Individual dose from meat and milk consumption is calculated in the same manner, using the equations

$$
\begin{aligned}
& \mathrm{D}_{\mathrm{i}}^{\text {meat }}=\mathrm{C}_{\mathrm{i}}^{\text {meat }} \cdot \mathrm{U}^{\mathrm{f}} \cdot \mathrm{DF}_{\mathrm{i}}^{\mathrm{ing}} \cdot 1000 \frac{\mathrm{mrem}}{\text { rem }} \cdot 1 \mathrm{yr} \\
& \mathrm{D}_{\mathrm{i}}^{\text {milk }}=\mathrm{C}_{\mathrm{i}}^{\text {milk }} \cdot \mathrm{U}^{\mathrm{m}} \cdot \mathrm{DF}_{\mathrm{i}}^{\text {ing }} \cdot 1000 \frac{\mathrm{mrem}}{\mathrm{rem}} \cdot 1 \mathrm{yr}
\end{aligned}
$$

The dose conversion factor for ingestion is nuclide specific and is the same value for water, vegetable, meat and milk consumption. Usage factors for vegetables, meat, and milk are shown in Table 6 for maximum and average individuals.

Table 6. Consumption Parameters (Hamby 1991)

\begin{tabular}{|l|c|c|}
\hline & \multicolumn{2}{|c|}{ Consumption Rate (kg/yr) } \\
\hline Parameter & Maximum & Average \\
\hline Vegetables & 276 & 163 \\
Meat & 81 & 43 \\
Milk & 230 & 120 \\
\hline
\end{tabular}

\section{VERIFICATION OF MODELS}

To verify MAXDOSE-SR, comparisons were made with MAXIGASP which has been fully verified. During initial comparisons, the two codes were not in agreement and MAXDOSESR was not executing properly for some of the test cases. Detailed comparisons demonstrated that differences in FORTRAN versions was the problem. Changes were made to MAXDOSE-SR as needed to achieve agreement between the codes. One subroutine that was used with MAXIGASP could not be located for use with MAXDOSE-SR. Only the executable was available. This subroutine, called SRP, was created from its inverse subroutine SRPLL. The subroutine SRPLL takes site coordinates in northing and easting and converts it the longitudinal and latitudinal coordinates and SRP was coded to perform the inverse of this function. This subroutine was verified by comparisons with spreadsheet calculations.

For verification purposes, comparisons were made with existing MAXIGASP test cases. The input for the test cases is shown in Table 7. The results of the comparison are shown in Table 8. Test Case numbers 4 and 9 showed small differences in MAXIGASP versus MAXDOSE- 
SR. The differences for Test Case number 4 result from slight differences in mathematical calculations performed in the two versions which are described in detail below.

Table 7. Test Cases for MAXDOSE-SR

\begin{tabular}{|c|c|c|c|c|c|c|c|c|c|c|}
\hline Parameter & CASE 1 & CASE 2 & CASE 3 & CASE 4 & CASE 5 & CASE 6 & CASE 7 & CASE 8 & CASE 9 & $\begin{array}{l}\text { CASE } \\
10^{* *}\end{array}$ \\
\hline No. Release Pts. & 1 & 1 & $\overline{1}$ & 1 & $2^{*}$ & $2^{*}$ & $2^{*}$ & $2^{*}$ & 1 & 1 \\
\hline $\begin{array}{l}\text { Operating Period } \\
\text { (yrs) }\end{array}$ & 200 & 200 & 50 & 1 & 1 & 100 & 100 & 50 & 201 & 201 \\
\hline $\begin{array}{l}\text { Consumption } \\
\text { Rates }\end{array}$ & MAX & AVG & AVG & MAX & AVG & MAX & AVG & MAX & MAX & MAX \\
\hline Milk Type & COW & COW & GOAT & GOAT & GOAT & COW & COW & GOAT & COW & Cow \\
\hline $\begin{array}{l}\text { Grade } \\
\text { Elevation(ft) }\end{array}$ & 300 & 1000 & 300 & 300 & 0 & 1000 & 0 & 0 & 0 & 0 \\
\hline Met Database & D & $\mathrm{C}$ & K & $\mathrm{H}$ & A & $\mathrm{P}$ & $\mathbf{H}$ & F & $\mathrm{H}$ & $\mathbf{H}$ \\
\hline $\begin{array}{l}\text { Release } \\
\text { Coordinate(E) }\end{array}$ & 20330 & 46200 & 41000 & 58000 & 51860 & 64800 & 63380 & 53970 & 58000 & 58000 \\
\hline $\begin{array}{l}\text { Release } \\
\text { Coordinate }(\mathrm{N})\end{array}$ & 65080 & 67600 & 53500 & 62000 & 106670 & 43800 & 71900 & 78020 & 62000 & 62000 \\
\hline $\begin{array}{l}\text { Ground Level or } \\
\text { Elevated }\end{array}$ & Ground & Elevated & Ground & Ground & Elevated & Elevated & Elevated & Ground & Ground & Ground \\
\hline $\begin{array}{l}\text { Vent Air Velocity } \\
(\mathrm{m} / \mathrm{s})\end{array}$ & 0 & 20 & 0 & 0 & 0 & 0 & 5 & 0 & 0 & 0 \\
\hline $\begin{array}{l}\text { Vent Inside } \\
\text { Diameter (m) }\end{array}$ & 0 & 10 & 0 & 0 & 0 & 0 & 10 & 0 & 0 & 0 \\
\hline $\begin{array}{l}\text { Rlease Height } \\
\text { (m) }\end{array}$ & 0 & -5 & 0 & 0 & -5 & -50 & -100 & 0 & 0 & 0 \\
\hline $\begin{array}{l}\text { Building Height } \\
\text { (m) }\end{array}$ & 100 & 0 & 0 & 100 & 0 & 25 & 50 & 0 & 0 & 0 \\
\hline $\begin{array}{l}\text { Vertical X- } \\
\text { Section (sq. m) }\end{array}$ & 0 & 500 & 0 & 500 & 500 & 250 & 0 & 500 & 0 & 0 \\
\hline $\begin{array}{l}\text { Selected Wind } \\
\text { Ht. (m) }\end{array}$ & 10 & 5 & 10 & 10 & 5 & 50 & 10 & 10 & 10 & 10 \\
\hline $\begin{array}{l}\text { Heat Emission } \\
\text { Rate }(\mathrm{cal} / \mathrm{s})\end{array}$ & 100 & 100 & 0 & 0 & 0 & 100 & 100 & 0 & 0 & 0 \\
\hline Elemental Iodine & 0 & 1 & 0.5 & 1 & 0.5 & 0 & 0.5 & 1 & 1 & 1 \\
\hline \multirow{5}{*}{$\begin{array}{l}\text { Source Nuclide - } \\
\mathrm{Ci} \\
\text { Activity (Ci) }\end{array}$} & $\mathrm{H}-3,1$ & H-3, 1 & $\mathrm{H}-3,1$ & H-3, 1 & $\mathrm{H}-3,1$ & $\mathrm{H}-3,1$ & $\mathrm{H}-3,1$ & $\mathrm{H}-3,1$ & $\mathrm{H}-3,1$ & H-3, 1 \\
\hline & $\operatorname{Ar}-41,1$ & Ar-41, 1 & Ar- $-41,1$ & Ar-41, 1 & Ar-41, 1 & Ar-41, 1 & Ar-41, 1 & Ar-41, 1 & Ar- 41,2 & Ar- 41,2 \\
\hline & & & $|\mathrm{I}-133,1|$ & $\mathrm{I}-133,1$ & & $\mathrm{I}-133,1$ & I-133, 1 & $\mathrm{I}-133,1$ & & $\begin{array}{l}\text { Pd- } \\
107,3\end{array}$ \\
\hline & $\begin{array}{c}\mathrm{Cs}-137 \\
1\end{array}$ & $\begin{array}{c}\text { Cs-137 } \\
1\end{array}$ & $\begin{array}{c}\text { Cs-137, } \\
1\end{array}$ & $\begin{array}{c}\text { Cs-137, } \\
1\end{array}$ & $\left|\begin{array}{c}\text { Cs-137, } \\
1\end{array}\right|$ & $\begin{array}{c}\text { Cs-137, } \\
1\end{array}$ & $\begin{array}{c}\mathrm{Cs}-137 \\
1\end{array}$ & $\begin{array}{c}\text { Cs-137 } \\
1\end{array}$ & $\begin{array}{c}\text { Cs-137, } \\
4\end{array}$ & I-133, 4 \\
\hline & $\begin{array}{l}\mathrm{U}-238, \\
1\end{array}$ & $\begin{array}{l}\mathrm{U}-238, \\
1\end{array}$ & $\begin{array}{l}U-238, \\
1\end{array}$ & $\begin{array}{l}\mathrm{U}-238 \\
1\end{array}$ & $\begin{array}{l}\mathrm{U}-238, \\
1\end{array}$ & $\begin{array}{l}\mathrm{U}-238 \\
1\end{array}$ & $\mid \begin{array}{l}\mathrm{U}-238 \\
1\end{array}$ & $\begin{array}{l}\mathrm{U}-238 \\
1\end{array}$ & $\begin{array}{l}\text { U-238, } \\
5\end{array}$ & $\begin{array}{c}\mathrm{Cs}-137 \\
5 \\
\mathrm{U}-238,6\end{array}$ \\
\hline
\end{tabular}

*Second release point from center of site with all other inputs the same.

** Designed to fail. 
Table 8. Results of Test Case Comparisons

\begin{tabular}{|c|c|c|c|}
\hline Test \# & MAXIGASP & MAXDOSE-SR & \% Diff \\
\hline 1 & 32.1 & 32.1 & $0.0 \%$ \\
2 & 3.23 & 3.23 & $0.0 \%$ \\
3 & 2.17 & 2.17 & $0.0 \%$ \\
4 & 0.788 & 0.800 & $1.5 \%$ \\
5 & 168 & 168 & $0.0 \%$ \\
6 & 2.10 & 2.10 & $0.0 \%$ \\
7 & 1.56 & 1.56 & $0.0 \%$ \\
8 & 3.13 & 3.13 & $0.0 \%$ \\
9 & 5.02 & 5.09 & $1.4 \%$ \\
10 & Failed & Failed & \\
\hline
\end{tabular}

For test case number 4, in MAXDOSE-SR and MAXIGASP the worst sector and distance were determined to be ENE, 8.71 miles and ENE, 8.80 miles, respectively. While these differences may seem slight, they can account for noticeable differences in the resulting dose that is calculated. The reason that different distances are used by the two codes is that in MAXDOSE-SR the boundary location that corresponded to the 8.71 miles discussed above was in the ENE sector whereas in MAXIGASP this boundary location was determined to be in the E sector. This results because of a slight difference in FORTRAN precision that result in different angles being calculated. While these differences are so small that the radian angle varies only in the sixth decimal place, this is enough to allow for the location to correspond to a different sector for certain instances such as this. For Test Case number 9, the differences occur for the same reason as test case 4 , because the release is from the same location. For radionuclides that are shorter lived, the differences could be more evident since radioactive decay is considered over the period of time it takes for the plume to travel to the receptor.

In order to ensure that MAXDOSE-SR was operating correctly, an additional number of test cases were executed and compared to MAXIGASP. The parameters for these test cases are shown in Appendix B. The results of this comparison are shown in Table 9.

Table 9. Additional Test Case Comparisons

\begin{tabular}{|c|c|c|c|}
\hline Test \# & MAXIGASP & MAXDOSE-SR & \% Diff \\
\hline 11 & $7.65 \mathrm{E}-06$ & $7.83 \mathrm{E}-06$ & $2.3 \%$ \\
12 & 0.0463 & 0.0463 & $0.00 \%$ \\
13 & 0.0685 & 0.0685 & $0.00 \%$ \\
14 & 45.1 & 45.1 & $0.00 \%$ \\
15 & Terminate* & Terminate* & \\
16 & 295 & 295 & $0.00 \%$ \\
17 & 0.0043 & 0.0043 & $0.00 \%$ \\
18 & 0.225 & 0.225 & $0.00 \%$ \\
\hline
\end{tabular}

*Radionuclide entered not in Dose Factor Library 
Test Case 11 showed a noticeable difference. Table 10 shows the detailed output of this test case. While the overall difference is small (2.3\%), some of the doses from specific radionuclides vary significantly. Since krypton- 89 showed the greatest difference, the results were examined in detail. The half life of krypton- 89 is short $(3.2 \mathrm{~min})$, therefore using a slightly different distance can have a considerable effect on the amount of decay. Since the release location is the same as Test Case 4, different distances were used as discussed above. These different distances resulted in different relative air concentrations being used to calculate the travel time (see equation 26) which resulted in a majority of the difference. The other minor difference is that a different decayed and depleted air concentration was used to calculate the plume shine dose.

Table 10. Results of Test Case 11

\begin{tabular}{|l|c|c|c|}
\hline Radionuclide & MAXIGASP & MAXDOSE-SR & \% Difference \\
\hline $\mathrm{Kr} 83 \mathrm{~m}$ & $1.22 \mathrm{E}-10$ & $1.25 \mathrm{E}-10$ & $2.4 \%$ \\
$\mathrm{Kr} 85 \mathrm{~m}$ & $3.87 \mathrm{E}-07$ & $3.94 \mathrm{E}-07$ & $1.8 \%$ \\
$\mathrm{Kr} 85$ & $.8 .07 \mathrm{E}-09$ & $8.18 \mathrm{E}-09$ & $1.3 \%$ \\
$\mathrm{Kr} 87$ & $7.35 \mathrm{E}-07$ & $7.60 \mathrm{E}-07$ & $3.3 \%$ \\
$\mathrm{Kr} 88$ & $5.53 \mathrm{E}-06$ & $5.66 \mathrm{E}-06$ & $2.3 \%$ \\
$\mathrm{Kr} 89$ & $3.26 \mathrm{E}-21$ & $5.35 \mathrm{E}-21$ & $39.1 \%$ \\
$\mathrm{Xe} 131 \mathrm{~m}$ & $3.07 \mathrm{E}-08$ & $3.11 \mathrm{E}-08$ & $1.3 \%$ \\
$\mathrm{Xe} 133 \mathrm{~m}$ & $1.04 \mathrm{E}-07$ & $1.05 \mathrm{E}-07$ & $1.0 \%$ \\
Xe 133 & $1.25 \mathrm{E}-07$ & $1.27 \mathrm{E}-07$ & $1.6 \%$ \\
Xe $135 \mathrm{~m}$ & $9.82 \mathrm{E}-10$ & $1.10 \mathrm{E}-09$ & $10.7 \%$ \\
Xe 135 & $7.32 \mathrm{E}-07$ & $7.44 \mathrm{E}-07$ & $1.6 \%$ \\
Xe 137 & $1.78 \mathrm{E}-19$ & $2.67 \mathrm{E}-19$ & $33.3 \%$ \\
Xe 138 & $1.55 \mathrm{E}-09$ & $1.75 \mathrm{E}-09$ & $11.4 \%$ \\
*TOTAL* & $7.65 \mathrm{E}-06$ & $7.83 \mathrm{E}-06$ & $2.3 \%$ \\
\hline
\end{tabular}

MAXIGASP has been compared with measured concentrations of tritium oxide in the environment (Simpkins and Hamby 1997). MAXIGASP over predicts measured values on average by a factor of $1.7 \pm 0.5$. This is exceptional agreement since Gaussian plume models typically over predict annual average air concentrations by a factor of two to four.

\section{USER'S MANUAL}

\subsection{First-time user instructions}

MAXDOSE-SR runs from an executable file created using Digital Visual FORTRAN Version 5.0. All necessary files are contained with one folder called "MAXDOSE." This folder must be placed directly on your C: Drive for the program to operate correctly. To execute the program click on "MAXDOSE.exe." From there, a DOS window will appear that will ask for the input file name. You must include the pathway (for example C:/MAXDOSE/INPUT/MAXTEST1). After the input file has been entered and the user 
presses enter, the code runs in a matter of seconds. Various output files may then be accessed from the folder called "OUTPUT." The most useful file is "MAXDOSE.DOC." Each of the output files are discussed in detail below.

\subsection{Input Instructions}

Figure 5 shows the input template in its entirety for test case 1. After each of the required inputs, the format is shown. All entries should be left justified to the "=" using the format that is specified. Since the input is read using a specific format in the FORTRAN, the user should not add any returns. The user should maintain a master input template and make appropriate copies for additional input files. This way the user can't inadvertently make changes to the master. The blank lines are contained within the user template to be consistent with previous input files. Formats have been maintained so that all previous input files will execute correctly with the new version of MAXDOSE

Figure 5. MAXDOSE-SR Input Template

USER INPUT DATA TEMPLATE FOR MAXDOSE-SR

Contact Ali Simpkins 5-9643 for more information.

User instructions and Verification contained in:

Simpkins, Ali. MAXDOSE-SR: A Routine Release Atmospheric

Dose Model Used at SRS, WSRC-TR-99-00281

Enter all inputs left justified to the equal sign.

Copy bracketed lines as needed for additional release points.

Those parameters with an "*' after them are usually not changed.

TITLE = MAXIGASP TEST CASE NUMBER 1

NUMBER OF RELEASED RADIONUCLIDES (I3) =5 


$\begin{array}{lll}\text { NUMBER OF RELEASE POINTS (I2) } & =1 \\ \text { OPERATING PERIOD, YEARS } & (F 3.0) & =50 * \\ \text { MAX OR AVG CONSUMPTION BY INDIVIDUALS (3A1) } & =\text { MAX* } \\ \text { COW OR GOAT MILK INGESTION } & \text { (4A1) } & =\text { COW* }\end{array}$

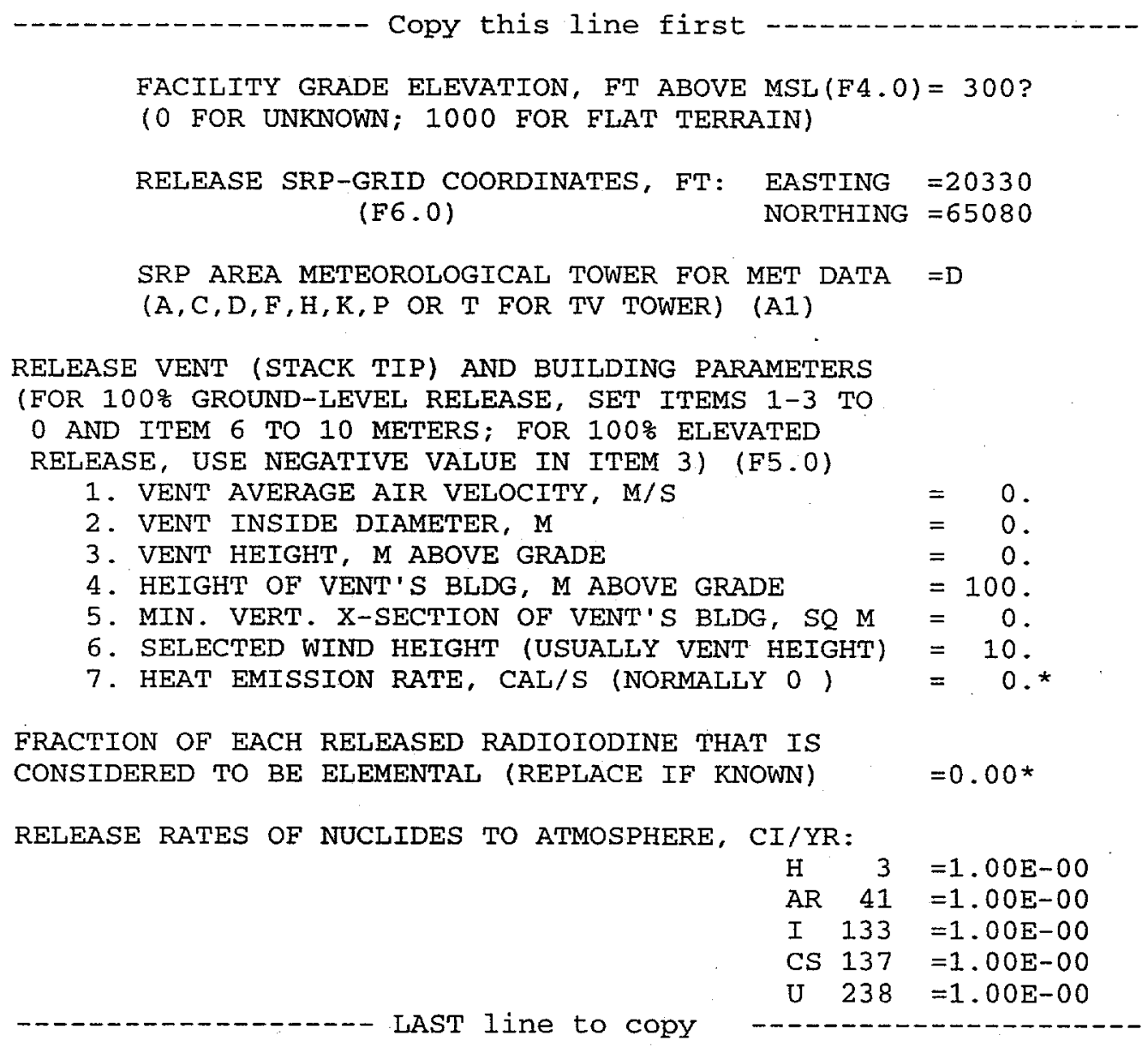

The following contains a detailed discussion of each of the input parameters.

TITLE = MAXIGASP TEST CASE NUMBER 1

The user can enter any type of descriptor for the run in the space after the ' $=$ '. This title will appear at the top of most of the output pages. 
The user is to enter the number of radionuclides to be released which is not to exceed 100 .

NUMBER OF RELEASE POINTS (I2)

The user enters the number of release points which is not to exceed five. See below for additional instructions on how to enter the information for each of the release points.

OPERATING PERIOD, YEARS (F3.0) $=50$ *

Enter the operating period in years. This is the length of time that the facility has been operating. Per USNRC Regulatory Guide 1.109, deposition buildup is assumed to occur for half of this period.

MAX OR AVG CONSUMPTION BY INDIVIDUALS (3A1) =MAX*

Enter whether you would like usage parameters accessed for maximum or average consumption by individuals. For a difference in the values used, see Table 6.

COW OR GOAT MILK INGESTION (4A1) = COW*

Enter either "Cow" or "Goat" as to the type of milk consumed. Different stable element transfer parameters will be used depending on which type of milk is selected.

The following block of data is to be copied for each release point that the user has specified. The copy is to be placed directly under the last line of the input.

Copy this line first

FACILITY GRADE ELEVATION, FT ABOVE MSL $(F 4.0)=300 ?$

(O FOR UNKNOWN; 1000 FOR FLAT TERRAIN)

Enter the facility grade elevation in feet above sea level. Enter ' 0 ' for unknown or ' 1000 ' for flat terrain. If ' 1000 ' is selected the terrain database will not be accessed to adjust for release height as the plume travels downwind.

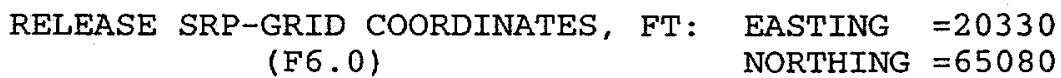

Enter the release coordinates in the site conventional system of Easting and Northing. Table 11 shows the stack location for some of the major facilities onsite. 
Table 11. Stack Coordinates for Major Facilities Onsite

\begin{tabular}{|c|r|r|}
\hline Stack Location & Easting & Northing \\
\hline A & 51863 & 106670 \\
D & 20330 & 65080 \\
F & 53970 & 78020 \\
H & 63380 & 71900 \\
K & 41000 & 53500 \\
L & 50460 & 45910 \\
M & 50040 & 104830 \\
P & 64800 & 43800 \\
\hline
\end{tabular}

SRP AREA METEOROLOGICAL TOWER FOR MET DATA =D (A, C, D, F, H, K, P OR T FOR TV TOWER) (A1)

Enter the meteorological tower that you wish to be accessed. Ideally, pick the one that is closest and has similar terrain

RELEASE VENT (STACK TIP) AND BUILDING PARAMETERS

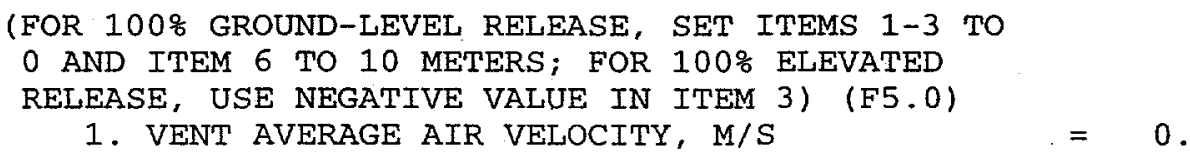

Enter the stack exit velocity in $\mathrm{m} / \mathrm{s}$. This will be used to calculate plume rise due to momentum of the plume. This parameter is typically set equal to ' 0 ' for conservatism.

$$
\text { 2. VENT INSIDE DIAMETER, M = } 0 \text {. }
$$

Enter the inside diameter of the stack/vent. This parameter will also be used to calculate plume rise effects.

3. VENT HEIGHT, M ABOVE GRADE = 0 .

Enter the height of the release in meters above grade. If the release is $100 \%$ elevated, use a negative sign in front of the number.

$$
\text { 4. HEIGHT OF VENT'S BLDG, M ABOVE GRADE }=100 \text {. }
$$

Enter the height of building. This number is used in equation 4 to determine if the building effects plume dispersion.

$$
\text { 5. MIN. VERT. X-SECTION OF VENT'S BLDG, } S Q M=0 \text {. }
$$

Enter the vertical cross-sectional area of the building.

$$
\text { 6. SELECTED WIND HEIGHT (USUALLY VENT HEIGHT) = } 10 \text {. }
$$

Enter the height to which the wind speed will be adjusted. This is usually the release height, unless the release is from ground level and then a wind speed height of $10 \mathrm{~m}$ is usually 
assumed. Wind measurements at SRS are taken at $61 \mathrm{~m}$ and a correction factor is applied (See Equation 1) to adjust the wind speed according to the appropriate height.

$$
\text { 7. HEAT EMISSION RATE, CAL/S (NORMALLY 0) = } 100 *(F 5.0)
$$

Enter heat emission rate, if known, in cal/s. This parameter is used for plume rise due to buoyancy effects.

FRACTION OF EACH RELEASED RADIOIODINE THAT IS

CONSIDERED TO BE ELEMENTAL (REPLACE IF KNOWN) =0.00* (F4.0)

Enter the fraction of radioiodine that is elemental, if known. This is used in Equations 22 and 24 to calculate the deposition rates and atmospheric concentrations of radioiodine.

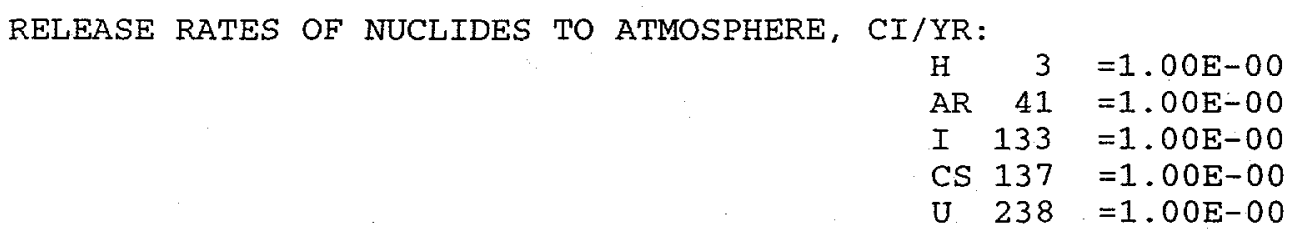

Enter the radionuclides that are released along with the respective release amounts in $\mathrm{Ci} / \mathrm{yr}$.

Appendix A contains a description of each of the data files that are used by MAXDOSE-SR.

\subsection{Output Files Generated}

For each MAXDOSE-SR run, several different output files are generated that contain a variety of data. The two files that users would find most useful are 'maxdose.doc' and 'mgdoses.xls.' These files will be discussed in greater detail below. All output files reside in 'C:Imaxdoseloutput.' All other files can be opened using Microsoft Word, and may be used for debugging purposes. It is usually necessary to first open Word and then open the files from within Word.

\subsubsection{MAXDOSE.DOC}

This file contains all the input and output that a user would need to verify a run. Once the file is opened, change the page layout to landscape for ease in viewing. Printing this file in its entirety would provide all the necessary information to reproduce the run for quality assurance purposes. A sample of the output is attached as Appendix C. Most of the output is self explanatory, but a brief discussion follows.

First, the input template is echoed just as the user entered it. This can be helpful, especially if something was entered incorrectly. A complete copy of the meteorological joint frequency distribution follows with averages and summaries at the end. Next, a table of terrain height is displayed as a function of distance from the release location and sector. Annual average $\chi /$ Qs are displayed with three different categories: no decay, undepleted; 2.26-day decay, 
undepleted; and 8.0-day decay and depleted. Relative deposition also is shown. Each of these tables is shown as a function of distance and sector.

A table containing relative air concentrations and relative depositions for each of the 320 equally spaced boundary locations is shown next in tabular form. Next, stable element transfer factors are displayed for all radionuclides followed by a listing of many of the constants used by MAXDOSE-SR. Maximum and average radionuclide air concentrations at the boundary are displayed for each of the radionuclides. Committed Effective Dose Equivalents (CEDEs) are shown for a variety of pathways and organs, broken down by radionuclide. The first dose table shows a total summary by pathway. The tables that follow show dose broken down by radionuclide and organ for the following pathways: plume shine, ground shine, vegetable consumption, meat consumption, milk consumption (cow or goat), and inhalation. The last table shows the total for all pathways summed together by radionuclide and organ. The final table in the printout shows air and ground concentrations as well as dose for each of the sectors. Also, the distance to the MEI in each sector is displayed.

\subsubsection{MGDOSES.XLS}

This file only contains doses and no input information is echoed. This file was designed for use in converting output to tabular form with greater ease. Doses are shown by pathway and organ and a table is included at the end that shows the total from all pathways. While this file is convenient for extracting data, other files are needed for verifying input.

\section{CONCLUSIONS}

MAXDOSE-SR is performing as expected and producing correct results for a wide range of test cases. Minimal input is required by the user and output is available in an easily interpreted form. Recommended improvements to MAXDOSE-SR include a user-friendly interface that would allow greater ease in entering input values. 


\section{REFERENCES}

Arnett, M.W. and Mamatey, A.R. 'Savannah River Site Environmental Data for 1997," Westinghouse Savannah River Co. Report WSRC-TR-97-00324, Aiken, SC 1998.

Arnett, M.W. and Mamatey, A.R. 'Savannah River Site Environmental Data for 1998," Westinghouse Savannah River Co. Report WSRC-TR-98-00314, Aiken, SC 1999.

Bauer, L.R., "QA And Update Of Boundary File Used By Axair89 And Maxigasp," Westinghouse Savannah River Company Inter-Office Memorandum SRL-ETS-90331, Aiken, SC, July 27, 1990.

Bauer, L.R., "Modeling Chronic Atmospheric Releases at the SRS: Evaluation and Verification of XOQDOQ," WSRC-RP-91-320, Westinghouse Savannah River Company, Aiken, SC, March 1991.

Bauer, L.R. and Hamby, D.M., "Relative Sensitivities of Existing and Novel Model Parameters in Atmospheric Tritium Dose Estimates," Radiation Protection Dosimetry, Volume 37, No. 4, pp. 253-260, 1991.

Briggs, G.A., Plume Rise, TID-25075, AEC Critical Review Series, Springfield, VA, 1969.

Eckerman, K.F., Congel, F.J., Roecklien, A.K., and Pasciak, W.J., "User's Guide to GASPAR Code," NUREG/-0597, U.S. Nuclear Regulatory Commission, Washington, DC, June 1980.

Eimutis, E.C., and Konicek, M.G., "Derivation of Continuous Functions for the Lateral and Vertical Dispersion Coefficients," Atmospheric Environment, 6:859-863, 1972.

Garrett, A.J., "Comparison of Observed Mixed-Layer Depths to Model Estimates Using Observed Temperatures and Winds, and MOS Forecasts," Journal of Applied Meteorology, 20:1277-1283, 1981.

Hamby, D.M., "Average Absolute Humidity at the Savannah River Site," Westinghouse Savannah River Company Inter-Office Memorandum: SRL-ETS-900141, Aiken, SC, March 22, 1990.

Hamby, D.M., "Land and Water-Use Characteristics in the Vicinity of the Savannah River Site," WSRC-RP-91-17, Westinghouse Savannah River Company, Aiken, SC, March 1991a.

Hamby, D.M., "Verification of the GASPR ICRP30 Dose Factor Library," SRL-ETS910583, Savannah River Laboratory, Aiken, SC, December 9, $1991 \mathrm{~b}$.

Hamby, D.M., "Verification of the GASPAR Noble Gas Dose Factor Library and SRS Site specific Data," SRL-ETS-910585, Savannah River Laboratory, Aiken, SC, December $10,1991 \mathrm{c}$. 
Hamby, D.M., "A Probabilistic Estimation of Atmospheric Tritium Dose," Health Physics, 65: 33-40, 1993.

Hamby, D.M., and Bauer, L.R., 'The vegetation-to-air concentration ratio in a specific activity atmospheric tritium model', Health Physics, 66:339-342, 1994.

Hunter, C.H., "A Climatological Description of the Savannah River Site," WSRC-RP-89313, Westinghouse Savannah River Company, Aiken, SC, May 22, 1990.

Markee, E.H., Jr., "A Parametric Study of Gaseous Plume Depletion by Ground Surface Absorption," Proceedings of USAEC Meteorological information Meeting, AECL2787, pp. 602-615, 1967.

National Council on Radiation Protection and Measurements (NCRP), "Radiological Assessment: Predicting the Transport, Bioaccumulation, and Uptake by Man of Radionuclides Released to the Environment," NCRP Report No. 76, Betheda, MD, 1984.

Netterville, D. J., "Plume Rise, Entrainment, and Dispersion in Turbulent Winds," Atmospheric Environment, 24A:1061-1081, 1990.

Parker, M.J. and Addis, R.P., "Meteorological Monitoring Program(U)," Westinghouse Savannah River Company Technical Report: WSRC-TR-93-0106, Aiken, SC 1993.

Pelletier, C.A., and Zimbrick, J.D., "Kinetics of Environmental Radiodine Transport Through the Milk-Food Chain," in Environmental Surveillance in the Vicinity of Nuclear Facilities, W.C. Reinig, ed., Charles C. Thomas Publishers, Springfield, VA, 1970.

Sagendorf, J.F., Goll, J.T., and Sandusky, W.F., "XOQDOQ: Computer Program for the Meteorological Evaluation of Routine Effluent Releases at Nuclear Power Stations," NUREG/CF-2919, U.S. Nuclear Regulatory Commission, Washington, DC, September 1982.

Simpkins, A.A. and Hamby, D.M. "Predicted versus Measured Tritium Oxide Concentrations at the Savannah River Site," Health Physics: 72(2):179-185, 1997.

Till, J.E., and Meyers, H.R. (eds), Radiological Assessment, NUREG/CF-3332, U.S. Nuclear Commission, Washington, DC, September 1983.

U.S. Nuclear Regulatory Commission, "Calculation of Annual Dose to Man from Routine Releases of Reactor Effluents for the Purpose of Evaluating Compliance with 10CFR50 Appendix I," Regulatory Guide 1.109, Rev 1, Washington, DC, October $1977 \mathrm{a}$.

U.S. Nuclear Regulatory Commission, "Methods for Estimating Atmospheric Transport and Dispersion of Gaseous Effluents in Routine Releases from Light-Water-Cooled Reactors," Regulatory Guide 1.111, Rev. 1, Washington, DC, July 1977b. 
Appendix A. MAXDOSE-SR Data Files

The following contains brief descriptions of the data files used by MAXDOSE-SR.

\section{AGRIMMV.DAT}

This file contains agricultural parameters for all sectors onsite. This information is used for population dose calculations. Milk, meat, and vegetable production are included for each sector and for 10 arcs which are bracketed by the following distances (in miles) from the center of the site: $0.5-1,1-2,2-3,3-4,4-5,5-10,10-20,20-30,30-40$, and 40-50. This data is taken from Hamby (1991).

\section{DOSEFACT.DAT}

This file contains the dose conversion factors used to calculate dose to the maximally exposed offsite individual. The first several entries are for the noble gases whose dose conversion factors have been modified to include contribution from the daughters as per Hamby (1991b). Dose conversion factors for all other radionuclides are shown next.

\section{MGPREGAS.DAT}

This file contains a variety of site specific information that is used to perform the dose calculations. Parameters for maximum and average individual are shown separately.

\section{SITEINFO.DAT}

This data file contains a small amount of site specific information.

\section{SRSBNDRY.DAT File}

The SRS boundary file contains 875 pairs of site coordinates which make up the site boundary. Section 2.1.2.1 discusses this file in greater detail. The first point corresponds to about the '9:00' position on the site boundary which is under the 'nose' on the west side.

\section{METEOROLOGICAL DATA Files}

Meteorological data files exist for each of the seven towers onsite. They are in the form of a joint frequency distribution by wind speed and stability class. Average wind speeds are also included in the files although they are not used by MAXDOSE-SR. 


\section{APPENDIX B. ADDITIONAL TEST CASE PARAMETERS}


Appendix B. Additional Test Case Parameters

Table B1. Additional Test Cases

\begin{tabular}{|c|c|c|c|c|c|c|c|c|}
\hline Parameter & $\begin{array}{c}\text { CASE } \\
11\end{array}$ & $\begin{array}{c}\text { CASE } \\
12\end{array}$ & $\begin{array}{c}\text { CASE } \\
13\end{array}$ & $\begin{array}{c}\text { CASE } \\
14\end{array}$ & \begin{tabular}{|c|} 
CASE \\
14 cont.
\end{tabular} & $\begin{array}{l}\text { CASE } \\
14 \text { cont. }\end{array}$ & $\begin{array}{c}\text { CASE } \\
14 \\
\text { cont. }\end{array}$ & $\begin{array}{c}\text { CASE } \\
14 \text { cont. }\end{array}$ \\
\hline No. Release Pts. & 1 & 5 & $\overline{5}$ & 5 & & & & \\
\hline $\begin{array}{l}\text { Operating Period } \\
(y r s)\end{array}$ & 80 & 88 & 90 & 88 & & & & \\
\hline Consumption Rates & MAX & MAX & MAX & MAX & & & & \\
\hline Milk Type & COW & COW & cow & COW & & & & \\
\hline Release Location & & & & 1 & 2 & 3 & 4 & 5 \\
\hline Grade Elevation(ft) & 0 & 350 & 350 & 350 & 350 & 150 & 350 & 350 \\
\hline Met Database & $\mathrm{H}$ & $*$ & $* *$ & $\mathrm{H}$ & A & $\mathrm{D}$ & A & $\mathrm{H}$ \\
\hline $\begin{array}{l}\text { Release } \\
\text { Coordinate(E) }\end{array}$ & 58000 & * & ** & 58000 & 50041 & 20938 & 51863 & 58000 \\
\hline $\begin{array}{l}\text { Release } \\
\text { Coordinate(N) }\end{array}$ & 62000 & $*$ & $* *$ & 62000 & 104828 & 65284 & 106670 & 62000 \\
\hline $\begin{array}{l}\text { Vent Air Velocity } \\
(\mathrm{m} / \mathrm{s})\end{array}$ & 0 & 0 & 0 & 0 & 0 & 0 & 0 & 0 \\
\hline $\begin{array}{l}\text { Vent Inside } \\
\text { Diameter (m) }\end{array}$ & 0 & 0 & 0 & 0 & 0 & 0 & 0 & 0 \\
\hline Release Height (m) & 0 & $*$ & $* *$ & 61 & 0 & 16 & 31 & 0 \\
\hline $\begin{array}{l}\text { Building Height } \\
\text { (m) }\end{array}$ & 0 & 0 & 0 & 0 & 0 & 0 & 0 & 0 \\
\hline $\begin{array}{l}\text { Vertical X-Section } \\
\text { (sq. m) }\end{array}$ & 0 & 0 & 0 & 0 & 0 & 0 & 0 & 0 \\
\hline $\begin{array}{l}\text { Selected Wind } \mathrm{Ht} \text {. } \\
(\mathrm{m})\end{array}$ & 10 & * & $* *$ & 61 & 10 & 16 & 31 & 0 \\
\hline $\begin{array}{l}\text { Heat Emission Rate } \\
(\mathrm{cal} / \mathrm{s})\end{array}$ & 0 & 0 & 0 & 0 & 0 & 0 & 0 & 0 \\
\hline Elemental Iodine & 1 & 1 & 1 & 1 & 1 & 1 & 1 & 1 \\
\hline $\begin{array}{l}\text { Source Term } \\
(\mathrm{Ci} / \mathrm{yr})\end{array}$ & $\begin{array}{c}1 \mathrm{Ci} \text { of } \\
\text { each } \\
\text { noble } \\
\text { gas }\end{array}$ & * & ** & $\begin{array}{c}\mathrm{H}-3,1000 \\
\text { Cs-137, } \\
0.1 \\
\mathrm{U}-235 \\
0.1 \\
\end{array}$ & \begin{tabular}{|}
$\mathrm{H}-3,0$ \\
$\mathrm{Cs}-137,0$ \\
$\mathrm{U}-235$ \\
1.0
\end{tabular} & $\begin{array}{c}\text { H-3,200 } \\
\text { Cs-137, } \\
0.1 \\
\text { U-235, } 0\end{array}$ & $\begin{array}{l}\text { H-3,100 } \\
\text { Cs-137, } \\
\text { U-235, } 0\end{array}$ & $\begin{array}{c}\mathrm{H}-3,200 \\
\text { Cs-137, } \\
0.2 \\
\text { U-235, } 0.1\end{array}$ \\
\hline
\end{tabular}

*See 1997 Environmental Report Cow Milk MEI Input Parameters (Arnett and Mamatey 1998)

** See 1998 Environmental Report Cow Milk MEI Input Parameters (Arnett and Mamatey 1999) 
Table B2. Additional Test Cases

\begin{tabular}{|c|c|c|c|c|c|c|c|c|}
\hline Parameter & $\begin{array}{c}\text { CASE } \\
15 \\
\end{array}$ & $\begin{array}{l}\text { CASE } \\
15 \text { cont }\end{array}$ & $\begin{array}{l}\text { CASE } \\
15 \text { cont } \\
\end{array}$ & $\begin{array}{c}\text { CASE } \\
15 \text { cont }\end{array}$ & $\begin{array}{l}\text { CASE } \\
15 \text { cont }\end{array}$ & $\begin{array}{c}\text { CASE } \\
16 \\
\end{array}$ & $\begin{array}{c}\text { CASE } \\
17 \\
\end{array}$ & $\begin{array}{c}\text { CASE } \\
18 \\
\end{array}$ \\
\hline No. Release Pts. & 5 & & & & & 1 & 1 & 1 \\
\hline $\begin{array}{l}\text { Operating Period } \\
\text { (yrs) }\end{array}$ & 88 & & & & & 200 & 50 & 50 \\
\hline Consumption Rates & MAX & & & & & MAX & MAX & MAX \\
\hline Milk Type & COW & & & & & COW & COW & COW \\
\hline Release Location & 1 & 2 & 3 & 4 & 5 & & & \\
\hline Grade Elevation $(\mathrm{ft})$ & 350 & 350 & 150 & 350 & 350 & 0 & 0 & 0 \\
\hline Met Database & $\mathrm{H}$ & A & D & A & $\mathrm{H}$ & A & K & $\mathrm{F}$ \\
\hline $\begin{array}{l}\text { Release } \\
\text { Coordinate(E) }\end{array}$ & 58000 & 50041 & 20938 & 51863 & 58000 & 51863 & 41000 & 154000 \\
\hline $\begin{array}{l}\text { Release } \\
\text { Coordinate }(\mathrm{N})\end{array}$ & 62000 & 104828 & 65284 & 106670 & 62000 & 106670 & 53500 & 78000 \\
\hline $\begin{array}{l}\text { Vent Air Velocity } \\
(\mathrm{m} / \mathrm{s})\end{array}$ & 0 & 0 & 0 & 0 & 0 & 0 & 0 & 0 \\
\hline $\begin{array}{l}\text { Vent Inside } \\
\text { Diameter }(m)\end{array}$ & 0 & 0 & 0 & 0 & 0 & 0 & 0 & 0 \\
\hline Release Height (m) & 61 & 0 & 16 & 31 & 0 & 30 & 0 & 0 \\
\hline $\begin{array}{l}\text { Building Height } \\
\text { (m) }\end{array}$ & 0 & 0 & 0 & 0 & 0 & 0 & 0 & 0 \\
\hline $\begin{array}{l}\text { Vertical X-Section } \\
\text { (sq. m) }\end{array}$ & 0 & 0 & 0 & 0 & 0 & 0 & 0 & 0 \\
\hline $\begin{array}{l}\text { Selected Wind Ht. } \\
\text { (m) }\end{array}$ & 61 & 10 & 16 & 31 & 0 & 30 & 10 & 10 \\
\hline $\begin{array}{l}\text { Heat Emission Rate } \\
(\mathrm{cal} / \mathrm{s})\end{array}$ & 0 & 0 & 0 & 0 & 0 & 0 & 0 & 0 \\
\hline Elemental Iodine & 1 & 1 & 1 & 1 & 1 & 1 & 1 & 1 \\
\hline $\begin{array}{l}\text { Source Term } \\
(\mathrm{Ci} / \mathrm{yr})\end{array}$ & $\begin{array}{c}\mathrm{Kr}-85 \\
1000 \\
\mathrm{U}-265, \\
0\end{array}$ & $\begin{array}{c}\mathrm{Kr}-85 \\
0 \\
\mathrm{U}-265 \\
1 \\
\end{array}$ & \begin{tabular}{|c}
$\mathrm{Kr}-85$ \\
0 \\
$\mathrm{U}-265$ \\
0 \\
\end{tabular} & $\begin{array}{c}\mathrm{Kr}-85 \\
100 \\
\mathrm{U}-265 \\
0 \\
\end{array}$ & $\begin{array}{c}\mathrm{Kr}-85 \\
100 \\
\mathrm{U}-265 \\
0 \\
\end{array}$ & $\begin{array}{c}\mathrm{Pu}-239 \\
1.0 \\
\mathrm{Cm}-244 \\
0.5 \\
\end{array}$ & $\begin{array}{l}\text { H-3 } \\
1000\end{array}$ & $\begin{array}{c}\text { Cs-137 } \\
1.0\end{array}$ \\
\hline
\end{tabular}




\section{APPENDIX C. SAMPLE OUTPUT FILE}




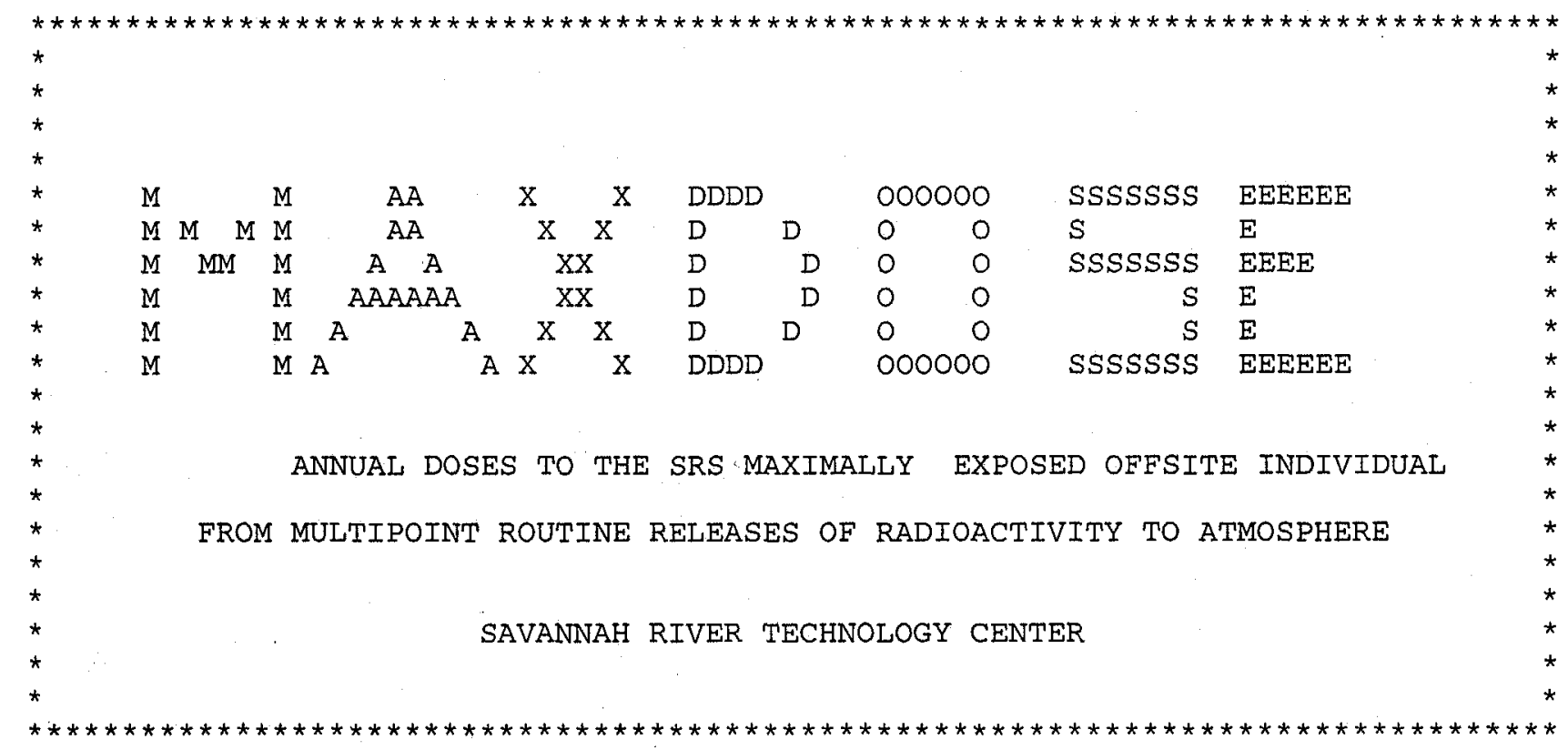

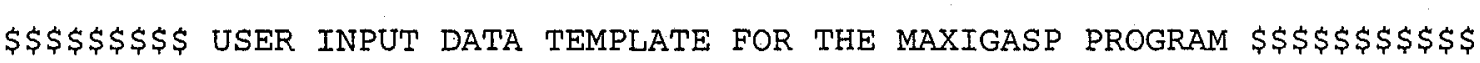

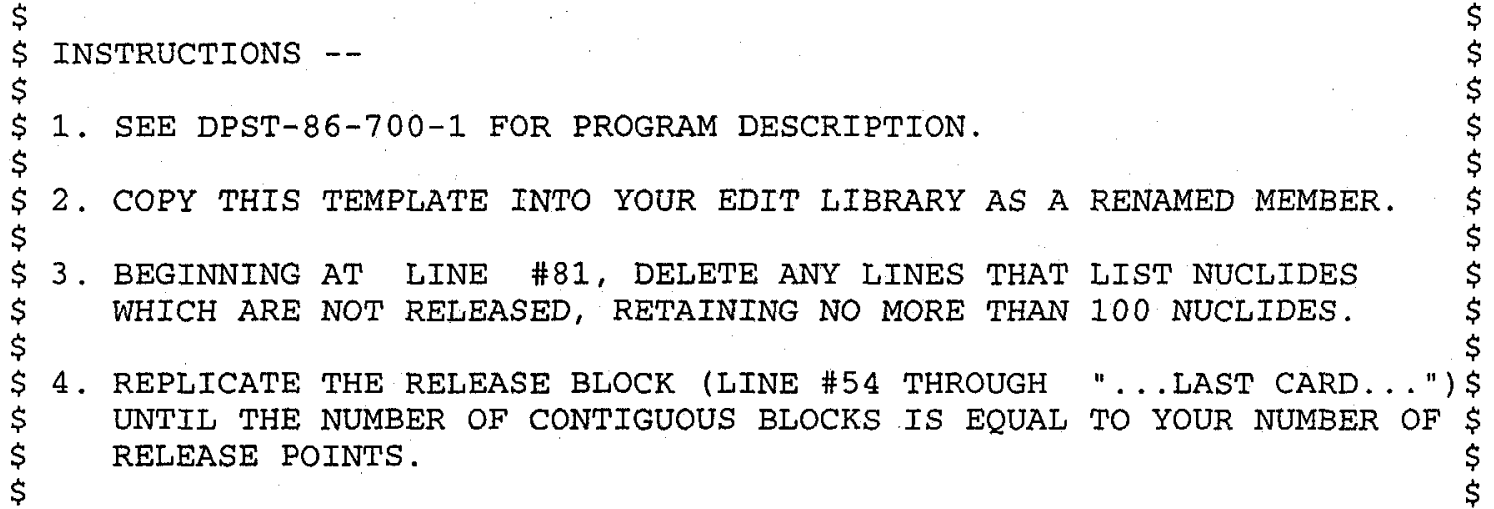




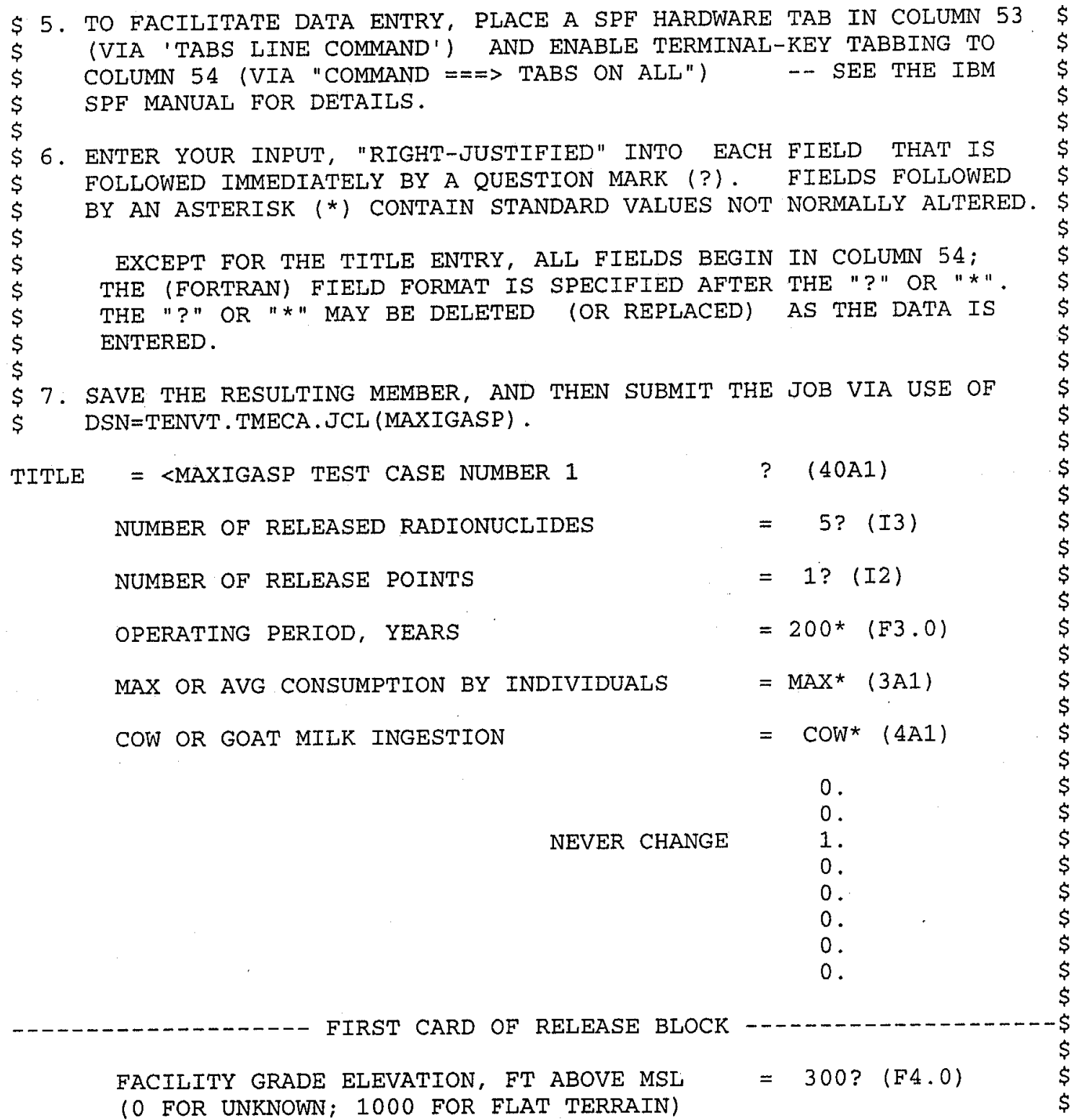




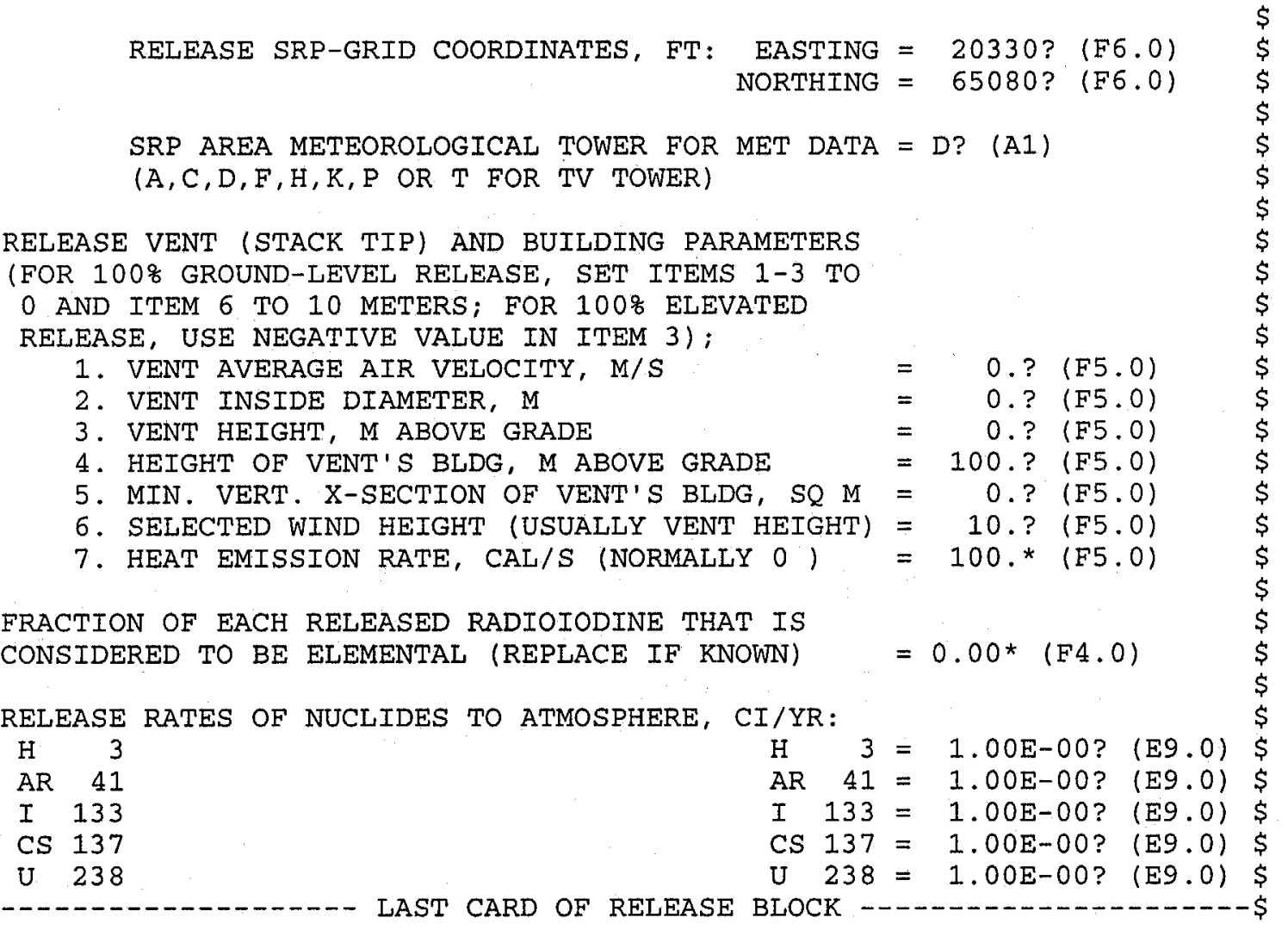

RELEASE VENT (STACK TIP) AND BUILDING PARAMETERS

(FOR 100\% GROUND-LEVEL RELEASE, SET ITEMS 1-3 TO

0 AND ITEM 6 TO 10 METERS; FOR 100\% ELEVATED

RELEASE, USE NEGATIVE VAIUE IN ITEM 3):

1. VENT AVERAGE AIR VELOCITY, M/S

4. HETGHT OF VENT'S BIDG, M AE

5. MIN. VERT. X-SECTION OF VENT'S BLDG, SQ $M=$

6. SELECTED WIND HEIGHT (USUALLY VENT HEIGHT)

7. HEAT EMISSION RATE, CAL/S (NORMALLY 0 ) LAST CARD OF RELEASE BLOCK CONSIDERED TO BE ELEMENTAL (REPLACE IF KNOWN)

IUSNRC COMPUTER CODE - XOQDOQ, VERSION 2.0

RUN DATE: $10 / 28 / 99$

42450 WIND STATS D_AREA 6OMIN 62M 92-96 STABILITY FROM SIGMA A

\begin{tabular}{|c|c|c|c|c|c|c|c|c|c|c|c|c|c|c|c|c|c|}
\hline JOINT & FREQ & & & & & & N. & & & & & 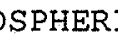 & $S$ & & LAS & . & \\
\hline $\mathrm{MX}-\mathrm{M} /$ & $S$ & NNE & $\mathrm{NE}$ & ENE & $\mathrm{E}$ & ESE & $S E$ & SSE & $S$ & SSW & SW & WSW & $W$ & WNW & NW & NNW & I \\
\hline & 0.544 & 0.516 & 0.363 & 0.353 & 0.320 & 0.323 & 346 & 0.452 & 0.471 & 0.488 & 554 & 0.528 & 53 & 0.523 & 502 & 5 & \\
\hline & 1. 218 & 11 & 04 & 0 & 02 & 48 & 51 & 0.455 & 21 & & & & & & & & \\
\hline & 0.424 & 0. & 43 & 0. & 0 & 0 & 1 & 0 & 40 & 0 & 0 & 0.137 & 8 & 0 & 9 & 7 & 05 \\
\hline & 0.028 & 0.1 & 0. & 0. & & 0 & 0. & & & & 7 & 7 & & & 21 & & \\
\hline & 0.000 & 0. & 0. & & Do & 02 & 0 & & 0 & & 0. & 2 & & & & & \\
\hline 4 & 0.000 & 00 & 0.000 & 00 & 00 & 0.000 & 0.000 & 0.000 & 0.000 & 100 & 0.000 & 0.000 & 00 & 0.000 & 0.000 & 0.000 & 00 \\
\hline
\end{tabular}


$\begin{array}{lllllllllllllllllll}\text { TOTAL } & 2.21 & 2.25 & 1.33 & 1.04 & 0.91 & 0.82 & 0.73 & 0.95 & 1.04 & 1.13 & 1.32 & 1.45 & 1.42 & 1.45 & 1.36 & 1.31 & 20.73\end{array}$ JOINT FREQUENCY DISTRIBUTION OF WIND SPEED AND DIRECTION ATMOSPHERIC STABILITY CLASS B UMX-M/S N NNE NE ENE $\quad$ E ESE SE SSE $S$ SSW SW WSW W WNW NW NNW TOTAL $\begin{array}{lllllllllllllllllllllll}2.00 & 0.153 & 0.137 & 0.101 & 0.097 & 0.099 & 0.078 & 0.092 & 0.122 & 0.099 & 0.106 & 0.106 & 0.127 & 0.104 & 0.134 & 0.108 & 0.115 & 1.779\end{array}$ $\begin{array}{llllllllllllllllllll}4.00 & 0.370 & 0.721 & 0.577 & 0.462 & 0.344 & 0.294 & 0.203 & 0.254 & 0.221 & 0.306 & 0.386 & 0.419 & 0.438 & 0.360 & 0.252 & 0.294 & 5.903\end{array}$ $\begin{array}{lllllllllllllllllll}6.00 & 0.042 & 0.337 & 0.610 & 0.290 & 0.134 & 0.073 & 0.047 & 0.092 & 0.099 & 0.153 & 0.299 & 0.445 & 0.313 & 0.261 & 0.184 & 0.101 & 3.482\end{array}$ $\begin{array}{llllllllllllllllllllll}8.00 & 0.000 & 0.047 & 0.122 & 0.016 & 0.000 & 0.005 & 0.002 & 0.005 & 0.002 & 0.012 & 0.035 & 0.125 & 0.113 & 0.127 & 0.068 & 0.024 & 0.704\end{array}$

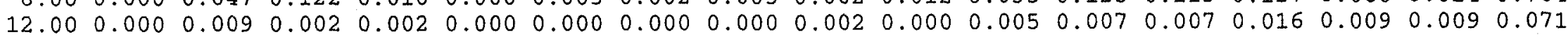
$\begin{array}{lllllllllllllllllllllllllllllllll}14.10 & 0.000 & 0.000 & 0.000 & 0.000 & 0.000 & 0.000 & 0.000 & 0.000 & 0.000 & 0.000 & 0.000 & 0.000 & 0.000 & 0.000 & 0.000 & 0.000 & 0.000\end{array}$

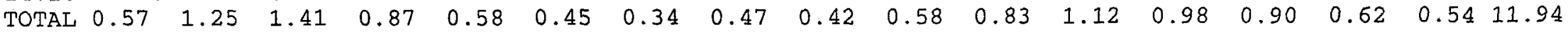

JOINT FREQUENCY DISTRIBUTION OF WIND SPEED AND DIRECTION ATMOSPHERIC STABILITY CLASS C

UMX-M/S N NNE NE ENE N ESE SE SSE $S$ SSW SW WSW W WNW NW NNW TOTAL

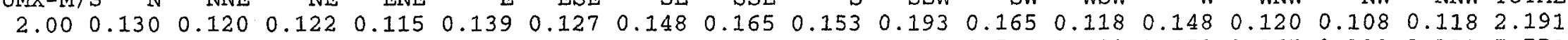

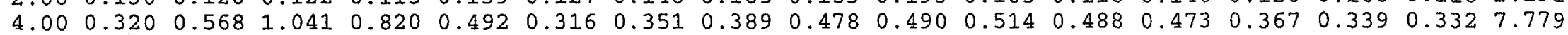
$\begin{array}{llllllllllllllllllll}6.00 & 0.035 & 0.217 & 1.053 & 0.761 & 0.337 & 0.177 & 0.170 & 0.229 & 0.214 & 0.342 & 0.528 & 0.669 & 0.681 & 0.499 & 0.283 & 0.068 & 6.261\end{array}$ $\begin{array}{llllllllllllllllll}8.00 & 0.000 & 0.002 & 0.245 & 0.163 & 0.045 & 0.024 & 0.033 & 0.033 & 0.024 & 0.134 & 0.179 & 0.259 & 0.483 & 0.676 & 0.177 & 0.014 & 2.490\end{array}$ $\begin{array}{lllllllllllllllllllllllllll}12.00 & 0.000 & 0.000 & 0.009 & 0.014 & 0.007 & 0.000 & 0.007 & 0.005 & 0.002 & 0.026 & 0.040 & 0.073 & 0.172 & 0.318 & 0.090 & 0.005 & 0.768\end{array}$ $\begin{array}{lllllllllllllllllllllllllll}14.10 & 0.000 & 0.000 & 0.000 & 0.000 & 0.000 & 0.000 & 0.000 & 0.000 & 0.000 & 0.000 & 0.000 & 0.000 & 0.009 & 0.016 & 0.000 & 0.000 & 0.026\end{array}$

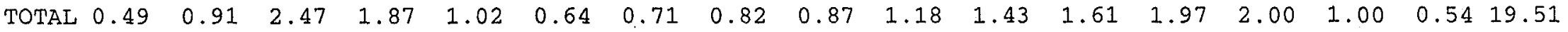

\section{JOINT FREQUENCY DISTRIBUTION OF WIND SPEED AND DIRECTION. ATMOSPHERIC STABILITY CLASS D}

UMX-M/S N NNE NE ENE E ESE SE SSE N S SSW SW WSW W WNW NW NNW TOTAL $\begin{array}{lllllllllllllllllllllll}2.00 & 0.078 & 0.108 & 0.118 & 0.158 & 0.139 & 0.122 & 0.203 & 0.229 & 0.165 & 0.212 & 0.231 & 0.226 & 0.198 & 0.153 & 0.085 & 0.120 & 2.544\end{array}$ $\begin{array}{lllllllllllllllll}4.00 & 0.184 & 0.379 & 0.963 & 0.914 & 0.707 & 0.709 & 1.053 & 1.411 & 1.439 & 1.204 & 0.933 & 0.667 & 0.789 & 0.495 & 0.457 & 0.38412 .688\end{array}$ $\begin{array}{lllllllllllllllllll}6.00 & 0.024 & 0.130 & 0.617 & 0.502 & 0.302 & 0.410 & 0.650 & 0.999 & 0.674 & 0.483 & 0.490 & 0.389 & 0.598 & 0.902 & 0.485 & 0.113 & 7.767\end{array}$ $\begin{array}{llllllllllllllllllll}8.00 & 0.000 & 0.007 & 0.059 & 0.064 & 0.024 & 0.057 & 0.210 & 0.372 & 0.177 & 0.170 & 0.054 & 0.005 & 0.052 & 0.240 & 0.191 & 0.009 & 1.689\end{array}$ $\begin{array}{llllllllllllllllllllllllllllll}12.00 & 0.000 & 0.000 & 0.007 & 0.005 & 0.002 & 0.002 & 0.042 & 0.101 & 0.071 & 0.073 & 0.005 & 0.000 & 0.002 & 0.021 & 0.019 & 0.000 & 0.351\end{array}$ $\begin{array}{lllllllllllllllllllllllllllllllllll}14.10 & 0.000 & 0.000 & 0.000 & 0.000 & 0.000 & 0.000 & 0.000 & 0.000 & 0.002 & 0.000 & 0.000 & 0.000 & 0.000 & 0.000 & 0.000 & 0.000 & 0.002\end{array}$

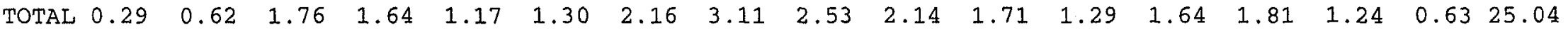

\section{JOINT FREQUENCY DISTRIBUTION OF WIND SPEED AND DIRECTION ATMOSPHERIC STABILITY CLASS E}

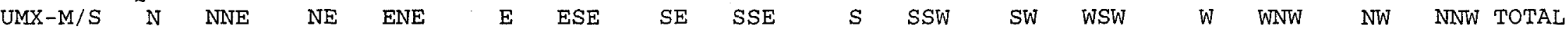

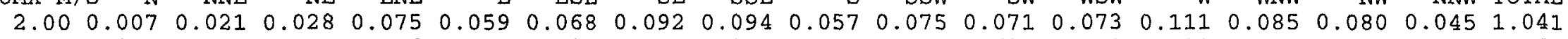
$\begin{array}{lllllllllllllllll}4.00 & 0.049 & 0.330 & 0.744 & 0.806 & 0.702 & 0.707 & 1.128 & 1.249 & 0.514 & 0.735 & 0.631 & 0.792 & 0.923 & 0.711 & 0.497 & 0.43310 .952\end{array}$ $\begin{array}{lllllllllllllllllll}6.00 & 0.014 & 0.188 & 0.544 & 0.405 & 0.252 & 0.221 & 0.596 & 0.794 & 0.125 & 0.203 & 0.229 & 0.231 & 0.203 & 0.563 & 0.403 & 0.179 & 5.150\end{array}$ $\begin{array}{llllllllllllllllllllllllll}8.00 & 0.000 & 0.002 & 0.007 & 0.007 & 0.000 & 0.000 & 0.009 & 0.024 & 0.002 & 0.002 & 0.000 & 0.000 & 0.000 & 0.002 & 0.000 & 0.000 & 0.057\end{array}$ $\begin{array}{llllllllllllllllllll}12.00 & 0.000 & 0.000 & 0.000 & 0.000 & 0.000 & 0.000 & 0.000 & 0.000 & 0.000 & 0.000 & 0.000 & 0.000 & 0.000 & 0.000 & 0.000 & 0.000 & 0.000\end{array}$

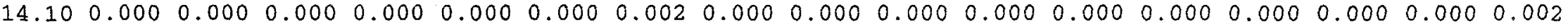

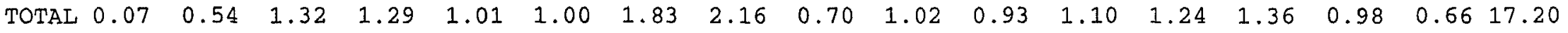




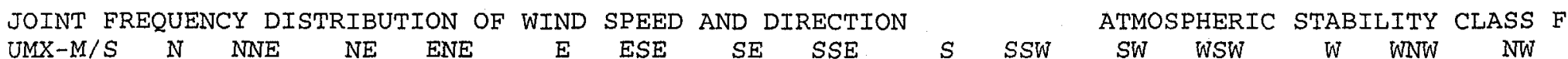

$\begin{array}{llllllllllllllllllllllllllll}2.00 & 0.000 & 0.000 & 0.002 & 0.007 & 0.009 & 0.014 & 0.014 & 0.005 & 0.000 & 0.000 & 0 & 000 & 0.000 & 0.005 & 0.009 & 0.016 & 0.014 & 0.097\end{array}$

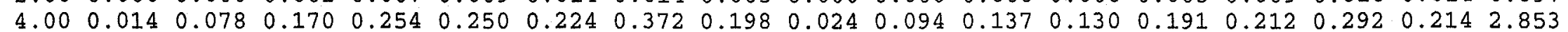
$\begin{array}{lllllllllllllllllllllll}6.00 & 0.000 & 0.059 & 0.224 & 0.294 & 0.151 & 0.099 & 0.132 & 0.099 & 0.005 & 0.064 & 0.092 & 0.141 & 0.049 & 0.151 & 0.283 & 0.243 & 2.085\end{array}$ $\begin{array}{lllllllllllllllllllllllllllllllllll}8.00 & 0.000 & 0.000 & 0.002 & 0.002 & 0.000 & 0.000 & 0.000 & 0.002 & 0.000 & 0.000 & 0.000 & 0.000 & 0.000 & 0.000 & 0.002 & 0.002 & 0.012\end{array}$

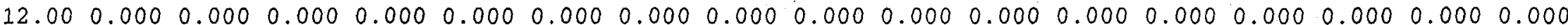
$\begin{array}{llllllllllllllllllllllll}14.10 & 0.000 & 0.000 & 0.000 & 0.000 & 0.000 & 0.000 & 0.000 & 0.000 & 0.000 & 0.000 & 0.000 & 0.000 & 0.000 & 0.000 & 0.000 & 0.000 & 0.000\end{array}$ $\begin{array}{llllllllllllllllll}\text { TOTAL } & 0.01 & 0.14 & 0.40 & 0.56 & 0.41 & 0.34 & 0.52 & 0.30 & 0.03 & 0.16 & 0.23 & 0.27 & 0.24 & 0.37 & 0.59 & 0.47 & 5.05\end{array}$

JOINT FREQUENCY DISTRIBUTION OF WIND SPEED AND DIRECTION ATMOSPHERIC STABILITY CLASS G

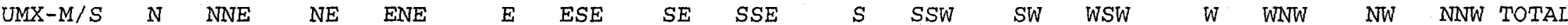
$\begin{array}{llllllllllllllllllllllllllllllllllll}2.00 & 0.000 & 0.000 & 0.000 & 0.000 & 0.000 & 0.000 & 0.000 & 0.000 & 0.000 & 0.000 & 0.000 & 0.000 & 0.000 & 0.000 & 0.002 & 0.000 & 0.002\end{array}$ $\begin{array}{lllllllllllllllllllllllllll}4.00 & 0.000 & 0.012 & 0.024 & 0.026 & 0.014 & 0.021 & 0.016 & 0.012 & 0.000 & 0.002 & 0.000 & 0.014 & 0.007 & 0.002 & 0.035 & 0.026 & 0.212\end{array}$ $\begin{array}{lllllllllllllllllllllllllllllll}6.00 & 0.000 & 0.019 & 0.021 & 0.049 & 0.033 & 0.009 & 0.016 & 0.014 & 0.000 & 0.002 & 0.002 & 0.005 & 0.009 & 0.019 & 0.064 & 0.042 & 0.306\end{array}$

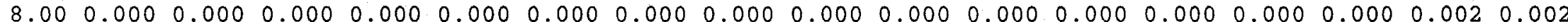

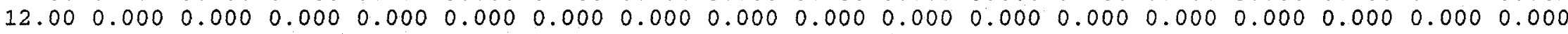

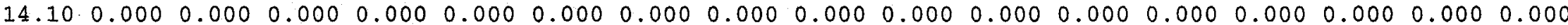
$\begin{array}{lllllllllllllllllllllll}\text { TOTAL } & 0.00 & 0.03 & 0.04 & 0.08 & 0.05 & 0.03 & 0.03 & 0.03 & 0.00 & 0.00 & 0.00 & 0.02 & 0.02 & 0.02 & 0.10 & 0.07 & 0.52\end{array}$

TOTAL HOURS CONSIDERED ARE 42450

OWIND MEASURED AT 62.0 METERS.

OOVERALL WIND DIRECTION FREQUENCY

WIND DIRECTION: N NNE NE ENE E ESE SE SSE S SSW SW WSW W WNW NW NNW TOTAL $\begin{array}{lllllllllllllllll}\text { FREOUENCY: } & 3.6 & 5.7 & 8.7 & 7.3 & 5.2 & 4.6 & 6.3 & 7.8 & 5.6 & 6.2 & 6.4 & 6.9 & 7.5 & 7.9 & 5.9 & 4.2100 .0\end{array}$

OOVERALL WIND SPEED FREQUENCY

MAX WIND SPEED (M/S): $\quad 2.000 \quad 4.000 \quad 6.000 \quad 8.000 \quad 12.000 \quad 14.100$

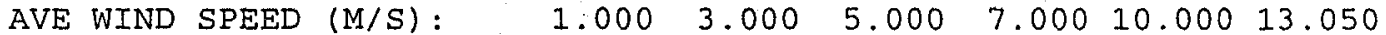

WIND SPEED FREQUENCY: $\quad \begin{array}{llllll}15.03 & 51.00 & 27.46 & 5.26 & 1.22 & 0.03\end{array}$

OTERRAIN HEIGHTS IN METERS AS A FUNCTION OF DIRECTION AND DISTANCE FROM THE SITE:

\begin{tabular}{|c|c|c|c|c|c|c|c|c|c|c|c|c|c|c|c|c|}
\hline & & & & & & DIRF & ION & & & & & & & & & \\
\hline DISTANCE & S & SSW & SW & WSW & $W$ & WNW & NW & NNW & $\mathrm{N}$ & NNE & $\mathrm{NE}$ & ENE & $\mathrm{E}$ & ESE & SE & SSE \\
\hline 1609.3 & 0.0 & 0.0 & 0.0 & 0.0 & 0.0 & 0.0 & 0.0 & 0.0 & 0.0 & 0.0 & 0.0 & 0.0 & 0.0 & 0.0 & 0.0 & 0.0 \\
\hline 3218.7 & 0.0 & 0.0 & 0.0 & 0.0 & 0.0 & 0.0 & 0.0 & 0.0 & 0.0 & 0.0 & 0.0 & 0.0 & 0.0 & 0.0 & 0.0 & 0.0 \\
\hline 4828.0 & 0.0 & 0.0 & 0.0 & 0.0 & 0.0 & 0.0 & 0.0 & 0.0 & 0.0 & 0.0 & 0.0 & 0.0 & 0.0 & 0.0 & 0.0 & 0.0 \\
\hline 6437.4 & 0.0 & 0.0 & 0.0 & 0.0 & 0.0 & 0.0 & 0.0 & 0.0 & 0.0 & 0.0 & 0.0 & 0.0 & 0.0 & 0.0 & 0.0 & 0.0 \\
\hline 8046.8 & 0.0 & 0.0 & 0.0 & 0.0 & 0.0 & 0.0 & 0.0 & 0.0 & 0.0 & 0.0 & 0.0 & $0: 0$ & 0.0 & 0.0 & 0.0 & 0.0 \\
\hline 9656.1 & 0.0 & 0.0 & 0.0 & 0.0 & 0.0 & 0.0 & 0.0 & 0.0 & 0.0 & 0.0 & 0.0 & 0.0 & 0.0 & 0.0 & 0.0 & 0.0 \\
\hline 11265.5 & 0.0 & 0.0 & 0.0 & 0.0 & 0.0 & 0.0 & 0.0 & 0.0 & 15.2 & 0.0 & 0.0 & 0.0 & 0.0 & 0.0 & 0.0 & 0.0 \\
\hline 12874.8 & 0.0 & 0.0 & 0.0 & 0.0 & 0.0 & 0.0 & 0.0 & 0.0 & 15.2 & 0.0 & 0.0 & 3.4 & 0.0 & 0.0 & 0.0 & 0.0 \\
\hline 14484.1 & 0.0 & 0.0 & 0.0 & 0.0 & 0.0 & 0.0 & 0.0 & 0.0 & 18.0 & 5.8 & 0.0 & 12.2 & 6.1 & 0.0 & 0.0 & 0.0 \\
\hline
\end{tabular}




$\begin{array}{rrrrrrrrrrrrrrrrr}16093.5 & 0.0 & 0.0 & 0.0 & 0.0 & 0.0 & 0.0 & 0.0 & 16.1 & 22.9 & 17.4 & 0.0 & 12.2 & 6.1 & 0.0 & 0.0 & 0.0 \\ 19312.2 & 0.0 & 0.0 & 0.0 & 0.0 & 0.0 & 0.0 & 0.0 & 30.5 & 33.5 & 29.9 & 0.0 & 12.2 & 6.1 & 4.0 & 0.0 & 0.0 \\ 22530.9 & 0.0 & 0.0 & 0.0 & 4.3 & 3.7 & 0.0 & 0.0 & 30.5 & 48.8 & 45.7 & 6.1 & 12.2 & 6.1 & 9.1 & 0.0 & 0.0 \\ 25749.6 & 0.0 & 0.0 & 3.0 & 6.1 & 15.2 & 12.5 & 0.0 & 31.1 & 48.8 & 45.7 & 11.9 & 12.2 & 6.1 & 9.1 & 0.0 & 0.0 \\ 28968.3 & 0.0 & 3.0 & 7.9 & 6.1 & 15.2 & 15.8 & 0.0 & 39.6 & 49.1 & 45.7 & 21.3 & 12.2 & 6.1 & 9.1 & 0.0 & 0.0 \\ 32187.0 & 0.0 & 21.3 & 18.3 & 6.1 & 15.2 & 24.4 & 15.2 & 48.8 & 60.9 & 45.7 & 31.4 & 12.2 & 6.1 & 9.1 & 0.0 & 0.0 \\ 40233.8 & 0.0 & 21.3 & 18.3 & 15.2 & 36.3 & 48.8 & 39.6 & 60.9 & 71.0 & 60.9 & 34.1 & 15.2 & 6.1 & 9.1 & 0.0 & 0.0 \\ 48280.5 & 6.1 & 21.3 & 30.5 & 30.5 & 40.8 & 72.8 & 66.7 & 76.2 & 76.2 & 64.6 & 34.1 & 15.2 & 6.1 & 9.1 & 0.0 & 0.0 \\ 56327.3 & 6.1 & 21.3 & 30.5 & 33.2 & 42.7 & 73.1 & 70.1 & 94.5 & 92.9 & 66.1 & 45.7 & 15.2 & 6.1 & 9.1 & 0.0 & 0.0 \\ 64374.0 & 6.1 & 21.3 & 30.5 & 33.2 & 60.9 & 73.1 & 70.1 & 108.8 & 112.7 & 79.2 & 60.9 & 15.2 & 6.1 & 9.1 & 0.0 & 0.0 \\ 72420.8 & 6.1 & 21.3 & 30.5 & 33.2 & 70.1 & 84.4 & 70.1 & 108.8 & 112.7 & 95.7 & 60.9 & 15.2 & 6.1 & 9.1 & 0.0 & 0.0 \\ 80467.5 & 6.1 & 21.3 & 30.5 & 33.2 & 77.1 & 91.4 & 70.1 & 108.8 & 112.7 & 109.7 & 60.9 & 15.2 & 6.1 & 9.1 & 0.0 & 0.0\end{array}$

IUSNRC COMPUTER CODE - XOQDOQ, VERSION 2.0 RUN DATE: 10/28/99

042450 WIND STATS D AREA 60MIN 62M 92-96 STABILITY FROM SIGMA A

NO DECAY, UNDEPLETED

OANNUAL AVERAGE CHI/Q (SEC/METER CUBED)

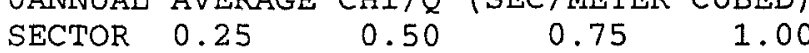

1.50 DISTANCE IN MILES FROM THE SITE

$52.22 E-06 \quad 5.75 E-07 \quad 2.71 E-07 \quad 1.65 E-07 \quad 8.81 E-08 \quad 5.67 E-08 \quad 4.06 E-08 \quad 3.10 E-08 \quad 2.47 E-08 \quad 2.04 E-08 \quad 1.72 E-08$

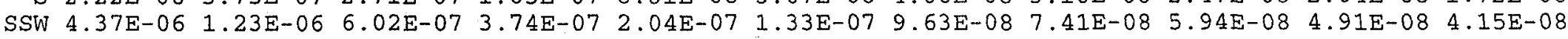
SW 7.85E-06 2.33E-06 $1.18 \mathrm{E}-06 \quad 7.45 \mathrm{E}-07 \quad 4.10 \mathrm{E}-07 \quad 2.68 \mathrm{E}-07 \quad 1.95 \mathrm{E}-07 \quad 1.50 \mathrm{E}-07 \quad 1.20 \mathrm{E}-07 \quad 9.95 \mathrm{E}-08 \quad 8.41 \mathrm{E}-08$ WSW 8.23E-06 2.43E-06 $1.23 \mathrm{E}-06 \quad 7.80 \mathrm{E}-07 \quad 4.32 \mathrm{E}-07 \quad 2.85 \mathrm{E}-07 \quad 2.09 \mathrm{E}-07 \quad 1.62 \mathrm{E}-07 \quad 1.30 \mathrm{E}-07 \quad 1.08 \mathrm{E}-07 \quad 9.18 \mathrm{E}-08$

W 6.40E-06 $1.88 \mathrm{E}-06 \quad 9.48 \mathrm{E}-07 \quad 6.01 \mathrm{E}-07 \quad 3.35 \mathrm{E}-07 \quad 2.21 \mathrm{E}-07 \quad 1.62 \mathrm{E}-07 \quad 1.26 \mathrm{E}-07 \quad 1.02 \mathrm{E}-07 \quad 8.47 \mathrm{E}-08 \quad 7.19 \mathrm{E}-08$ WNW 6.00E-06 $1.75 \mathrm{E}-06 \quad 8.87 \mathrm{E}-07 \quad 5.65 \mathrm{E}-07 \quad 3.17 \mathrm{E}-07 \quad 2.11 \mathrm{E}-07 \quad 1.55 \mathrm{E}-07 \quad 1.21 \mathrm{E}-07 \quad 9.76 \mathrm{E}-08 \quad 8.12 \mathrm{E}-08 \quad 6.90 \mathrm{E}-08$

NW 8.99E-06 $2.64 \mathrm{E}-06 \quad 1.35 \mathrm{E}-06 \quad 8.62 \mathrm{E}-07 \quad 4.89 \mathrm{E}-07 \quad 3.27 \mathrm{E}-07 \quad 2.41 \mathrm{E}-07 \quad 1.88 \mathrm{E}-07 \quad 1.52 \mathrm{E}-07 \quad 1.27 \mathrm{E}-07 \quad 1.08 \mathrm{E}-07$ NNW 9.72E-06 2.85E-06 $1.46 \mathrm{E}-06 \quad 9.42 \mathrm{E}-07 \quad 5.38 \mathrm{E}-07 \quad 3.60 \mathrm{E}-07 \quad 2.64 \mathrm{E}-07 \quad 2.05 \mathrm{E}-07 \quad 1.65 \mathrm{E}-07 \quad 1.37 \mathrm{E}-07 \quad 1.16 \mathrm{E}-07$

N 5.54E-06 $1.60 \mathrm{E}-06 \quad 8.37 \mathrm{E}-07 \quad 5.42 \mathrm{E}-07 \quad 3.05 \mathrm{E}-07 \quad 2.02 \mathrm{E}-07 \quad 1.46 \mathrm{E}-07 \quad 1.12 \mathrm{E}-07 \quad 8.98 \mathrm{E}-08 \quad 7.40 \mathrm{E}-08 \quad 6.23 \mathrm{E}-08$ NNE 6.68E-06 $1.95 \mathrm{E}-06 \quad 1.00 \mathrm{E}-06 \quad 6.44 \mathrm{E}-07 \quad 3.62 \mathrm{E}-07 \quad 2.39 \mathrm{E}-07 \quad 1.74 \mathrm{E}-07 \quad 1.34 \mathrm{E}-07 \quad 1.08 \mathrm{E}-07 \quad 8.91 \mathrm{E}-08 \quad 7.53 \mathrm{E}-08$ $\mathrm{NE} 6.57 \mathrm{E}-06 \quad 1.91 \mathrm{E}-06 \quad 9.73 \mathrm{E}-07 \quad 6.21 \mathrm{E}-07 \quad 3.46 \mathrm{E}-07 \quad 2.28 \mathrm{E}-07 \quad 1.66 \mathrm{E}-07 \quad 1.28 \mathrm{E}-07 \quad 1.03 \mathrm{E}-07 \quad 8.52 \mathrm{E}-08 \quad 7.20 \mathrm{E}-08$ ENE $6.84 \mathrm{E}-06 \quad 1.99 \mathrm{E}-06 \quad 1.00 \mathrm{E}-06 \quad 6.36 \mathrm{E}-07 \quad 3.55 \mathrm{E}-07 \quad 2.34 \mathrm{E}-07 \quad 1.71 \mathrm{E}-07 \quad 1.32 \mathrm{E}-07 \quad 1.06 \mathrm{E}-07 \quad 8.80 \mathrm{E}-08 \quad 7.45 \mathrm{E}-08$

$\mathrm{E} 7.64 \mathrm{E}-06 \quad 2.23 \mathrm{E}-06 \quad 1.13 \mathrm{E}-06 \quad 7.18 \mathrm{E}-07 \quad 4.02 \mathrm{E}-07 \quad 2.66 \mathrm{E}-07 \quad 1.94 \mathrm{E}-07 \quad 1.50 \mathrm{E}-07 \quad 1.21 \mathrm{E}-07 \quad 1.00 \mathrm{E}-07 \quad 8.49 \mathrm{E}-08$ ESE 7.56E-06 2.20E-06 1.11E-06 7.03E-07 3.93E-07 2.60E-07 $1.91 E-07 \quad 1.48 E-07 \quad 1.19 E-07 \quad 9.90 E-08 \quad 8.40 E-08$ SE $6.90 \mathrm{E}-06 \quad 1.99 \mathrm{E}-06 \quad 9.89 \mathrm{E}-07 \quad 6.23 \mathrm{E}-07 \quad 3.46 \mathrm{E}-07 \quad 2.29 \mathrm{E}-07 \quad 1.69 \mathrm{E}-07 \quad 1.32 \mathrm{E}-07 \quad 1.07 \mathrm{E}-07 \quad 8.96 \mathrm{E}-08 \quad 7.63 \mathrm{E}-08$ SSE 5.30E-06 1.51E-06 $7.46 \mathrm{E}-07 \quad 4.69 \mathrm{E}-07 \quad 2.59 \mathrm{E}-07 \quad 1.71 \mathrm{E}-07 \quad 1.26 \mathrm{E}-07 \quad 9.87 \mathrm{E}-08 \quad 8.01 \mathrm{E}-08 \quad 6.69 \mathrm{E}-08 \quad 5.70 \mathrm{E}-08$ OANNUAL AVERAGE CHI/Q (SEC/METER CUBED)

$\begin{array}{llcccccccccccc}\text { SECTOR } & 5.00 & 7.50 & 10.00 & 15.00 & 20.00 & 25.00 & 30.00 & 35.00 & 40.00 & 45.00 & 50.00\end{array}$

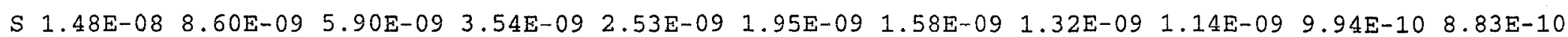
SSW 3.59E-08 2.07E-08 $1.41 \mathrm{E}-08 \quad 8.31 \mathrm{E}-09 \quad 5.79 \mathrm{E}-09 \quad 4.39 \mathrm{E}-09 \quad 3.50 \mathrm{E}-09 \quad 2.90 \mathrm{E}-09 \quad 2.46 \mathrm{E}-09 \quad 2.13 \mathrm{E}-09 \quad 1.87 \mathrm{E}-09$ SW 7.25E-08 4.13E-08 2.78E-08 1.61E-08 $1.10 \mathrm{E}-08 \quad 8.26 \mathrm{E}-09 \quad 6.53 \mathrm{E}-09 \quad 5.35 \mathrm{E}-09 \quad 4.51 \mathrm{E}-09 \quad 3.88 \mathrm{E}-09 \quad 3.40 \mathrm{E}-09$ 
WSW 7.94E-08 4.55E-08 3.08E-08 $1.79 \mathrm{E}-08 \quad 1.23 \mathrm{E}-08 \quad 9.19 \mathrm{E}-09 \quad 7.26 \mathrm{E}-09 \quad 5.95 \mathrm{E}-09 \quad 5.01 \mathrm{E}-09 \quad 4.31 \mathrm{E}-09 \quad 3.76 \mathrm{E}-09$ W 6.22E-08 3.58E-08 2.42E-08 $\quad 1.41 \mathrm{E}-08 \quad 9.68 \mathrm{E}-09 \quad 7.24 \mathrm{E}-09 \quad 5.72 \mathrm{E}-09 \quad 4.69 \mathrm{E}-09 \quad 3.95 \mathrm{E}-09 \quad 3.39 \mathrm{E}-09 \quad 2.96 \mathrm{E}-09$ WNW $5.97 \mathrm{E}-08 \quad 3.44 \mathrm{E}-08 \quad 2.33 \mathrm{E}-08 \quad 1.35 \mathrm{E}-08 \quad 9.25 \mathrm{E}-09 \quad 6.90 \mathrm{E}-09 \quad 5.44 \mathrm{E}-09 \quad 4.45 \mathrm{E}-09 \quad 3.74 \mathrm{E}-09 \quad 3.21 \mathrm{E}-09 \quad 2.80 \mathrm{E}-09$

NW $9.32 \mathrm{E}-08 \quad 5.36 \mathrm{E}-08 \quad 3.62 \mathrm{E}-08 \quad 2.09 \mathrm{E}-08 \quad 1.43 \mathrm{E}-08 \quad 1.06 \mathrm{E}-08 \quad 8.33 \mathrm{E}-09 \quad 6.80 \mathrm{E}-09 \quad 5.70 \mathrm{E}-09 \quad 4.88 \mathrm{E}-09 \quad 4.25 \mathrm{E}-09$

NNW 1.01E-07 5.73E-08 3.85E-08 2.20E-08 $1.49 \mathrm{E}-08 \quad 1.11 \mathrm{E}-08 \quad 8.65 \mathrm{E}-09 \quad 7.04 \mathrm{E}-09 \quad 5.89 \mathrm{E}-09 \quad 5.03 \mathrm{E}-09 \quad 4.38 \mathrm{E}-09$

$\mathrm{N} 5.35 \mathrm{E}-08 \quad 2.99 \mathrm{E}-08 \quad 1.98 \mathrm{E}-08 \quad 1.12 \mathrm{E}-08 \quad 7.54 \mathrm{E}-09 \quad 5.56 \mathrm{E}-09 \quad 4.35 \mathrm{E}-09 \quad 3.53 \mathrm{E}-09 \quad 2.95 \mathrm{E}-09 \quad 2.52 \mathrm{E}-09 \quad 2.19 \mathrm{E}-09$

NNE $6.48 \mathrm{E}-08 \quad 3.66 \mathrm{E}-08 \quad 2.44 \mathrm{E}-08 \quad 1.40 \mathrm{E}-08 \quad 9.47 \mathrm{E}-09 \quad 7.03 \mathrm{E}-09 \quad 5.51 \mathrm{E}-09 \quad 4.49 \mathrm{E}-09 \quad 3.76 \mathrm{E}-09 \quad 3.22 \mathrm{E}-09 \quad 2.81 \mathrm{E}-09$

$\mathrm{NE} \quad 6.21 \mathrm{E}-08 \quad 3.52 \mathrm{E}-08 \quad 2.36 \mathrm{E}-08 \quad 1.36 \mathrm{E}-08 \quad 9.25 \mathrm{E}-09 \quad 6.89 \mathrm{E}-09 \quad 5.42 \mathrm{E}-09 \quad 4.43 \mathrm{E}-09 \quad 3.73 \mathrm{E}-09 \quad 3.20 \mathrm{E}-09 \quad 2.79 \mathrm{E}-09$

ENE 6 $43 E-08$ 3.68E-08 2.48E-08 $1.43 E-08 \quad 9.84 E-09 \quad 7.35 E-09 \quad 5.80 E-09 \quad 4.75 E-09 \quad 4.00 E-09 \quad 3.44 E-09 \quad 3.01 E-09$

$\mathrm{E} 7.33 \mathrm{E}-08 \quad 4.18 \mathrm{E}-08 \quad 2.81 \mathrm{E}-08 \quad 1.62 \mathrm{E}-08 \quad 1.11 \mathrm{E}-08 \quad 8.29 \mathrm{E}-09 \quad 6.54 \mathrm{E}-09 \quad 5.35 \mathrm{E}-09 \quad 4.50 \mathrm{E}-09 \quad 3.86 \mathrm{E}-09 \quad 3.37 \mathrm{E}-09$

ESE 7.26E-08 $4.17 \mathrm{E}-08 \quad 2.82 \mathrm{E}-08 \quad 1.63 \mathrm{E}-08 \quad 1.12 \mathrm{E}-08 \quad 8.37 \mathrm{E}-09 \quad 6.60 \mathrm{E}-09 \quad 5.41 \mathrm{E}-09 \quad 4.55 \mathrm{E}-09 \quad 3.91 \mathrm{E}-09 \quad 3.42 \mathrm{E}-09$

$\mathrm{SE} 6.62 \mathrm{E}-08 \quad 3.86 \mathrm{E}-08 \quad 2.64 \mathrm{E}-08 \quad 1.56 \mathrm{E}-08 \quad 1.08 \mathrm{E}-08 \quad 8.11 \mathrm{E}-09 \quad 6.44 \mathrm{E}-09 \quad 5.30 \mathrm{E}-09.4 .48 \mathrm{E}-09 \quad 3.86 \mathrm{E}-09 \quad 3.38 \mathrm{E}-09$

SSE $4.95 \mathrm{E}-08 \quad 2.89 \mathrm{E}-08 \quad 1.99 \mathrm{E}-08 \quad 1.17 \mathrm{E}-08 \quad 8.15 \mathrm{E}-09 \quad 6.15 \mathrm{E}-09 \quad 4.89 \mathrm{E}-09 \quad 4.03 \mathrm{E}-09 \quad 3.41 \mathrm{E}-09 \quad 2.94 \mathrm{E}-09 \quad 2.58 \mathrm{E}-09$ OVENT AND BUILDING PARAMETERS:

$\begin{array}{lll}\text { RELEASE HEIGHT } & \text { (METERS) } & 0.00 \\ \text { DIAMETER } & \text { (METERS) } & 0.00 \\ \text { EXIT VELOCITY } & \text { (METERS) } & 0.00\end{array}$

REP. WIND HEIGHT

BUILDING HEIGHT

BLDG . MIN . CRS . SEC . AREA

(METERS)

10.0

EXIT VELOCITY (METERS) 0.00

HEAT EMISSION RATE

(METERS)

(SQ.METERS)

100.0

(CAL/SEC)

0.0

100.0

OALL GROUND LEVEL RELEASES.

1USNRC COMPUTER CODE - XOQDOQ, VERSION 2.0

RUN DATE: $10 / 28 / 99$

42450 WIND STATS D_AREA 60MIN 62M 92-96 STABILITY FROM SIGMA A

NO DECAY, UNDEPLETED

OCHI/Q (SEC/METER CUBED) FOR EACH SEGMENT

\begin{tabular}{|c|c|c|c|c|c|c|c|c|c|c|}
\hline DIRECTION & TION & $1-2$ & $2-3$ & $3-$ & $4-5$ & $5-10$ & $10-20$ & $20-30$ & $30-40$ & $40-50$ \\
\hline \multicolumn{11}{|c|}{ FROM SITE } \\
\hline$S$ & $2.91 E-07$ & $9.12 \mathrm{E}-08$ & $4.10 E-08$ & $2.48 E-08$ & $1.72 \mathrm{E}-08$ & $8.78 E-09$ & $3.61 E-09$ & 1.9 & 1.32 & $.95 E-10$ \\
\hline SSW & $40 \mathrm{E}-07$ & $2.10 E-07$ & $72 \mathrm{E}-08$ & $.97 \mathrm{E}-08$ & $4.17 \mathrm{E}-08$ & $2.11 E-08$ & $8.47 E-09$ & $4.41 E-09$ & $2.90 E-09$ & $2.13 E-09$ \\
\hline SW & $24 E-06$ & 4. $22 \mathrm{E}-07$ & $1.97 \mathrm{E}-07$ & 1. $21 \mathrm{E}-07$ & $8.44 \mathrm{E}-08$ & $4.22 \mathrm{E}-08$ & $1.64 \mathrm{E}-08$ & $8.31 E-09$ & $7 E-09$ & $3.89 E-09$ \\
\hline WSW & 1. $30 E-06$ & $4.44 \mathrm{E}-07$ & $2.10 E-07$ & $1.31 E-07$ & $9.21 \mathrm{E}-08$ & $4.65 \mathrm{E}-08$ & $1.83 E-08$ & $9.24 \mathrm{E}-09$ & -09 & $E-09$ \\
\hline $\mathrm{W}$ & 1. $00 \mathrm{E}-06$ & $3.43 \mathrm{E}-07$ & 1. $64 \mathrm{E}-07$ & $1.02 E-07$ & $7.21 E-08$ & $3.65 \mathrm{E}-08$ & 1. $44 \mathrm{E}-08$ & $7.28 E-09$ & 4.7 & $3.40 \mathrm{E}-09$ \\
\hline WNW & $9.36 \mathrm{E}-07$ & $3.25 \mathrm{E}-07$ & $1.56 \mathrm{E}-07$ & $9.80 E-08$ & $6.92 E-08$ & $3.51 E-08$ & 1. $38 E-08$ & $6.94 \mathrm{E}-09$ & $4.46 E-09$ & 3. $22 \mathrm{E}-09$ \\
\hline $\mathrm{NW}$ & 1.42 & .07 & 2.431 & $1.53 \mathrm{E}-07$ & $1.08 \mathrm{E}-07$ & $5.47 E-08$ & $2.14 E-08$ & $1.07 E-08$ & $6.82 \mathrm{E}-09$ & $4.89 E-09$ \\
\hline NNW & 1.5 & $.48 \mathrm{E}$ & 2.661 & $1.66 \mathrm{E}-07$ & $1.17 \mathrm{E}-07$ & $5.85 \mathrm{E}-08$ & $2.25 E-08$ & $1.11 E-08$ & $7.06 E-09$ & $5.04 E-09$ \\
\hline $\mathrm{N}$ & 8.76 & 3.121 & $1.47 \mathrm{E}$ & $9.02 \mathrm{E}$ & $6.25 \mathrm{E}$ & 3.0 & 1.1 & $5.60 E-09$ & $3.54 E-09$ & $2.52 E-09$ \\
\hline NNE & 1. $05 E-06$ & $3.70 E-07$ & $1.76 \mathrm{E}-07$ & $1.08 \mathrm{E}-07$ & $7.55 \mathrm{E}-08$ & 3.75 & 1.4 & -09 & 4.5 & $3.23 E-09$ \\
\hline $\mathrm{NE}$ & $1.02 E-06$ & $3.55 E-07$ & $1.68 \mathrm{E}-07$ & $1.03 \mathrm{E}-07$ & $7.22 \mathrm{E}-08$ & $3.60 \mathrm{E}-08$ & -08 & -09 & 09 & $2-09$ \\
\hline ENE & $1.06 \mathrm{E}-06$ & $3.64 E-07$ & $1.72 E-07$ & $1.07 \mathrm{E}-07$ & $7.47 E-08$ & $3.76 \mathrm{E}-08$ & $1.47 \mathrm{E}-08$ & $9 E-09$ & -09 & $5 E-09$ \\
\hline$E$ & 1. $19 \mathrm{E}-06$ & $4.12 \mathrm{E}-07$ & $1.96 \mathrm{E}-07$ & $1.21 \mathrm{E}-07$ & $8.52 E-08$ & $4.27 E-08$ & $1.66 \mathrm{E}-08$ & $8.34 E-09$ & $5.36 \mathrm{E}-09$ & $3.87 E-09$ \\
\hline ESE & $1.17 \mathrm{E}-06$ & $.03 E-07$ & $1.92 \mathrm{E}-07$ & $1.20 \mathrm{E}-07$ & $8.42 \mathrm{E}-08$ & $4.25 E-08$ & $1.67 E-08$ & $8.42 E-09$ & $5.43 E-09$ & $3.92 E-09$ \\
\hline
\end{tabular}


$\mathrm{SE} \quad 1.05 \mathrm{E}-06 \quad 3.56 \mathrm{E}-07 \quad 1.71 \mathrm{E}-07 \quad 1.08 \mathrm{E}-07 \quad 7.65 \mathrm{E}-08 \quad 3.93 \mathrm{E}-08 \quad 1.59 \mathrm{E}-08 \quad 8.15 \mathrm{E}-09 \quad 5.31 \mathrm{E}-09 \quad 3.86 \mathrm{E}-09$ $\begin{array}{llllllllllll}\mathrm{SSE} & 7.93 \mathrm{E}-07 & 2.67 \mathrm{E}-07 & 1.27 \mathrm{E}-07 & 8.04 \mathrm{E}-08 & 5.72 \mathrm{E}-08 & 2.95 \mathrm{E}-08 & 1.19 \mathrm{E}-08 & 6.18 \mathrm{E}-09 & 4.04 \mathrm{E}-09 & 2.95 \mathrm{E}-09\end{array}$ IUSNRC COMPUTER CODE - XOQDOQ, VERSION 2.0 RUN DATE: 10/28/99

042450 WIND STATS D_AREA 60MIN 62M 92-96 STABILITY FROM SIGMA A

2.260 DAY DECAY, UNDEPLETED

OANNUAL AVERAGE CHI/Q (SEC/METER CUBED)

SECTOR $0.25 \quad 0.50 \quad 0.75 \quad 1.00$

1.50

DISTANCE IN MILES FROM THE SITE

$\begin{array}{lllllllllllllll}S & 2.22 E-06 & 5.73 E-07 & 2.70 E-07 & 1.64 E-07 & 8.73 E-08 & 5.60 E-08 & 3.99 E-08 & 3.04 E-08 & 2.42 E-08 & 1.99 E-08 & 1.67 E-08\end{array}$

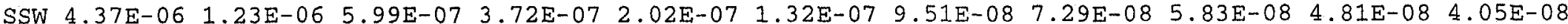
SW 7.84E-06 2.33E-06 $1.18 \mathrm{E}-06 \quad 7.42 \mathrm{E}-07 \quad 4.07 \mathrm{E}-07 \quad 2.66 \mathrm{E}-07 \quad 1.93 \mathrm{E}-07 \quad 1.48 \mathrm{E}-07 \quad 1.19 \mathrm{E}-07 \quad 9.78 \mathrm{E}-08 \quad 8.25 \mathrm{E}-08$ WSW 8.22E-06 2.43E-06 $1.23 \mathrm{E}-06 \quad 7.76 \mathrm{E}-07 \quad 4.29 \mathrm{E}-07 \quad 2.82 \mathrm{E}-07 \quad 2.06 \mathrm{E}-07 \quad 1.59 \mathrm{E}-07 \quad 1.28 \mathrm{E}-07 \quad 1.06 \mathrm{E}-07 \quad 8.97 \mathrm{E}-08$

W 6.39E-06 $1.87 \mathrm{E}-06 \quad 9.44 \mathrm{E}-07 \quad 5.98 \mathrm{E}-07 \quad 3.32 \mathrm{E}-07 \quad 2.19 \mathrm{E}-07 \quad 1.60 \mathrm{E}-07 \quad 1.24 \mathrm{E}-07 \quad 1.00 \mathrm{E}-07 \quad 8.29 \mathrm{E}-08 \quad 7.02 \mathrm{E}-08$ WNW 5.99E-06 $1.75 \mathrm{E}-06 \quad 8.83 \mathrm{E}-07 \quad 5.62 \mathrm{E}-07 \quad 3.15 \mathrm{E}-07 \quad 2.09 \mathrm{E}-07 \quad 1.53 \mathrm{E}-07 \quad 1.19 \mathrm{E}-07 \quad 9.57 \mathrm{E}-08 \quad 7.94 \mathrm{E}-08 \quad 6.73 \mathrm{E}-08$

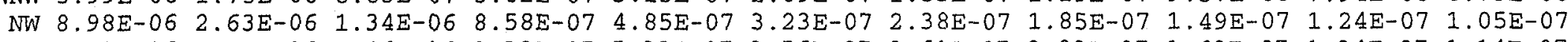
NNW 9.70E-06 2.84E-06 $1.46 \mathrm{E}-06 \quad 9.38 \mathrm{E}-07 \quad 5.33 \mathrm{E}-07 \quad 3.56 \mathrm{E}-07 \quad 2.61 \mathrm{E}-07 \quad 2.02 \mathrm{E}-07 \quad 1.62 \mathrm{E}-07 \quad 1.34 \mathrm{E}-07 \quad 1.14 \mathrm{E}-07$

N 5.53E-06 1.60E-06 8.34E-07 5.39E-07 3.03E-07 2.00E-07 $1.44 \mathrm{E}-07 \quad 1.11 \mathrm{E}-07 \quad 8.82 \mathrm{E}-08 \quad 7.24 \mathrm{E}-08 \quad 6.09 \mathrm{E}-08$ $\mathrm{NNE} 6.67 \mathrm{E}-06 \quad 1.94 \mathrm{E}-06 \quad 9.99 \mathrm{E}-07 \quad 6.40 \mathrm{E}-07 \quad 3.59 \mathrm{E}-07 \quad 2.37 \mathrm{E}-07 \quad 1.72 \mathrm{E}-07 \quad 1.32 \mathrm{E}-07 \quad 1.06 \mathrm{E}-07 \quad 8.72 \mathrm{E}-08 \quad 7.35 \mathrm{E}-08$

NE $6.56 \mathrm{E}-06 \quad 1.90 \mathrm{E}-06 \quad 9.69 \mathrm{E}-07 \quad 6.17 \mathrm{E}-07 \quad 3.43 \mathrm{E}-07 \quad 2.26 \mathrm{E}-07 \quad 1.64 \mathrm{E}-07 \quad 1.26 \mathrm{E}-07 \quad 1.01 \mathrm{E}-07 \quad 8.33 \mathrm{E}-08 \quad 7.02 \mathrm{E}-08$ ENE 6.83E-06 $1.98 E-06 \quad 9.98 E-07 \quad 6.32 E-07 \quad 3.52 E-07 \quad 2.32 E-07 \quad 1.69 E-07 \quad 1.30 E-07 \quad 1.04 E-07 \quad 8.61 E-08 \quad 7.27 E-08$

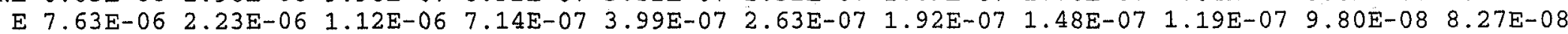
ESE 7.55E-06 2.20E-06 $1.10 \mathrm{E}-06 \quad 6.99 \mathrm{E}-07 \quad 3.90 \mathrm{E}-07 \quad 2.58 \mathrm{E}-07 \quad 1.88 \mathrm{E}-07 \quad 1.46 \mathrm{E}-07 \quad 1.17 \mathrm{E}-07 \quad 9.69 \mathrm{E}-08 \quad 8.20 \mathrm{E}-08$

SE $6.89 \mathrm{E}-06 \quad 1.98 \mathrm{E}-06 \quad 9.85 \mathrm{E}-07 \quad 6.20 \mathrm{E}-07 \quad 3.43 \mathrm{E}-07 \quad 2.27 \mathrm{E}-07 \quad 1.67 \mathrm{E}-07 \quad 1.30 \mathrm{E}-07 \quad 1.05 \mathrm{E}-07 \quad 8.76 \mathrm{E}-08 \quad 7.45 \mathrm{E}-08$ SSE 5.29E-06 1.51E-06 7.43E-07. 4.66E-07 2.57E-07 1.69E-07 $1.25 E-07 \quad 9.71 E-08 \quad 7.86 E-08 \quad 6.54 E-08 \quad 5.56 E-08$ OANNUAL AVERAGE CHI/Q (SEC/METER CUBED) DISTANCE IN MILES FROM THE SITE

$\begin{array}{llllllllll}\text { SECTOR } & 5.00 & 7.50 & 10.00 & 15.00 & 20.00 & 25.00 & 30.00 & 35.00 & 40.00\end{array}$

S 1.44E-08 8.21E-09 5.54E-09 3.23E-09 2.24E-09 1.67E-09 1.32E-09 $1.07 \mathrm{E}-09 \quad 8.95 \mathrm{E}-10 \quad 7.61 \mathrm{E}-10 \quad 6.57 \mathrm{E}-10$ SSW 3.49E-08 1.99E-08 1.34E-08 7.69E-09 5.23E-09 3.86E-09 3.01E-09 2.43E-09 2.01E-09 $1.70 \mathrm{E}-09 \quad 1.46 \mathrm{E}-09$ SW 7.09E-08 $3.99 \mathrm{E}-08 \quad 2.66 \mathrm{E}-08 \quad 1.50 \mathrm{E}-08 \quad 1.01 \mathrm{E}-08 \quad 7.40 \mathrm{E}-09 \quad 5.72 \mathrm{E}-09 \quad 4.59 \mathrm{E}-09 \quad 3.79 \mathrm{E}-09 \quad 3.19 \mathrm{E}-09 \quad 2.73 \mathrm{E}-09$ WSW 7.74E-08 4.38E-08 2.92E-08 1.66E-08 $1.11 \mathrm{E}-08$ 8.10E-09 $6.25 \mathrm{E}-09 \quad 5.00 \mathrm{E}-09 \quad 4.11 \mathrm{E}-09 \quad 3.45 \mathrm{E}-09 \quad 2.95 \mathrm{E}-09$

$\begin{array}{llllllllllll}W & 6.06 \mathrm{E}-08 & 3.44 \mathrm{E}-08 & 2.30 \mathrm{E}-08 & 1.30 \mathrm{E}-08 & 8.70 \mathrm{E}-09 & 6.34 \mathrm{E}-09 & 4.88 \mathrm{E}-09 & 3.89 \mathrm{E}-09 & 3.20 \mathrm{E}-09 & 2.68 \mathrm{E}-09 & 2.28 \mathrm{E}-09\end{array}$ WNW $5.81 \mathrm{E}-08 \quad 3.29 \mathrm{E}-08 \quad 2.20 \mathrm{E}-08 \quad 1.24 \mathrm{E}-08 \quad 8.27 \mathrm{E}-09 \quad 6.00 \mathrm{E}-09 \quad 4.60 \mathrm{E}-09 \quad 3.66 \mathrm{E}-09 \quad 3.00 \mathrm{E}-09 \quad 2.50 \mathrm{E}-09 \quad 2.13 \mathrm{E}-09$ NW $9.08 E-08 \quad 5.15 E-08 \quad 3.43 E-08 \quad 1.93 E-08 \quad 1.28 E-08 \quad 9.29 E-09 \quad 7.11 E-09 \quad 5.65 E-09 \quad 4.62 E-09 \quad 3.86 E-09 \quad 3.27 E-09$ NNW 9.80E-08 5.51E-08 3.65E-08 2.04E-08 $1.35 E-08 \quad 9.73 E-09 \quad 7.43 E-09 \quad 5.90 E-09 \quad 4.81 E-09 \quad 4.01 E-09 \quad 3.40 E-09$

$\mathrm{N} 5.21 \mathrm{E}-08 \quad 2.87 \mathrm{E}-08 \quad 1.88 \mathrm{E}-08 \quad 1.03 \mathrm{E}-08 \quad 6.78 \mathrm{E}-09 \quad 4.87 \mathrm{E}-09 \quad 3.70 \mathrm{E}-09 \quad 2.93 \mathrm{E}-09 \quad 2.38 \mathrm{E}-09 \quad 1.98 \mathrm{E}-09 \quad 1.68 \mathrm{E}-09$ $\mathrm{NNE} \quad 6.31 \mathrm{E}-08 \quad 3.51 \mathrm{E}-08 \quad 2.31 \mathrm{E}-08 \quad 1.28 \mathrm{E}-08 \quad 8.48 \mathrm{E}-09 \quad 6.12 \mathrm{E}-09 \quad 4.67 \mathrm{E}-09 \quad 3.71 \mathrm{E}-09 \quad 3.03 \mathrm{E}-09 \quad 2.52 \mathrm{E}-09 \quad 2.14 \mathrm{E}-09$

$\mathrm{NE} \quad 6.04 \mathrm{E}-08 \quad 3.38 \mathrm{E}-08 \quad 2.23 \mathrm{E}-08 \quad 1.25 \mathrm{E}-08 \quad 8.28 \mathrm{E}-09 \quad 6.00 \mathrm{E}-09 \quad 4.60 \mathrm{E}-09 \quad 3.66 \mathrm{E}-09 \quad 2.99 \mathrm{E}-09 \quad 2.50 \mathrm{E}-09 \quad 2.13 \mathrm{E}-09$ ENE 6.26E-08 3.53E-08 2.34E-08 $\quad 1.32 E-08 \quad 8.81 E-09 \quad 6.41 E-09 \quad 4.92 E-09 \quad 3.93 E-09 \quad 3.22 E-09 \quad 2.70 E-09 \quad 2.30 E-09$

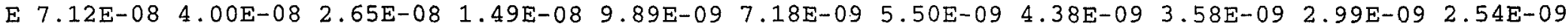


ESE 7.07E-08 4.00E-08 2.67E-08 1.51E-08 1.01E-08 7.33E-09 5.64E-09 4.51E-09 3.70E-09.3.10E-09 2.64E-09 SE $6.45 \mathrm{E}-08 \quad 3.70 \mathrm{E}-08 \quad 2.50 \mathrm{E}-08 \quad 1.44 \mathrm{E}-08 \quad 9.67 \mathrm{E}-09 \quad 7.09 \mathrm{E}-09 \quad 5.48 \mathrm{E}-09 \quad 4.39 \mathrm{E}-09 \quad 3.62 \mathrm{E}-09 \quad 3.04 \mathrm{E}-09 \quad 2.60 \mathrm{E}-09$ SSE $4.81 \mathrm{E}-08 \quad 2.77 \mathrm{E}-08 \quad 1.88 \mathrm{E}-08 \quad 1.08 \mathrm{E}-08 \quad 7.29 \mathrm{E}-09 \quad 5.35 \mathrm{E}-09 \quad 4.14 \mathrm{E}-09 \quad 3.32 \mathrm{E}-09 \quad 2.74 \mathrm{E}-092.30 \mathrm{E}-09 \quad 1.97 \mathrm{E}-09$ OVENT AND BUILDING PARAMETERS:

$\begin{array}{lll}\text { RELEASE HEIGHT } & \text { (METERS) } & 0.00 \\ \text { DIAMETER } & \text { (METERS) } & 0.00 \\ \text { EXIT VELOCITY } & \text { (METERS) } & 0.00\end{array}$

OALL GROUND LEVEL RELEASES

1USNRC COMPUTER CODE - XOQDOQ, VERSION 2.0
REP. WIND HETGHT

BUILDING HEIGHT

BLDG . MIN . CRS . SEC . AREA

HEAT EMISSION RATE
(METERS)

(METERS)

(SQ.METERS)

(CAL/SEC)
10.0 100.0

$$
0.0
$$

42450 WIND STATS D_AREA 6OMIN 62M 92-96 STABILITY FROM SIGMA A

2.260 DAY DECAY, UNDEPLETED

OCHI/Q (SEC/METER CUBED) FOR EACH SEGMENT

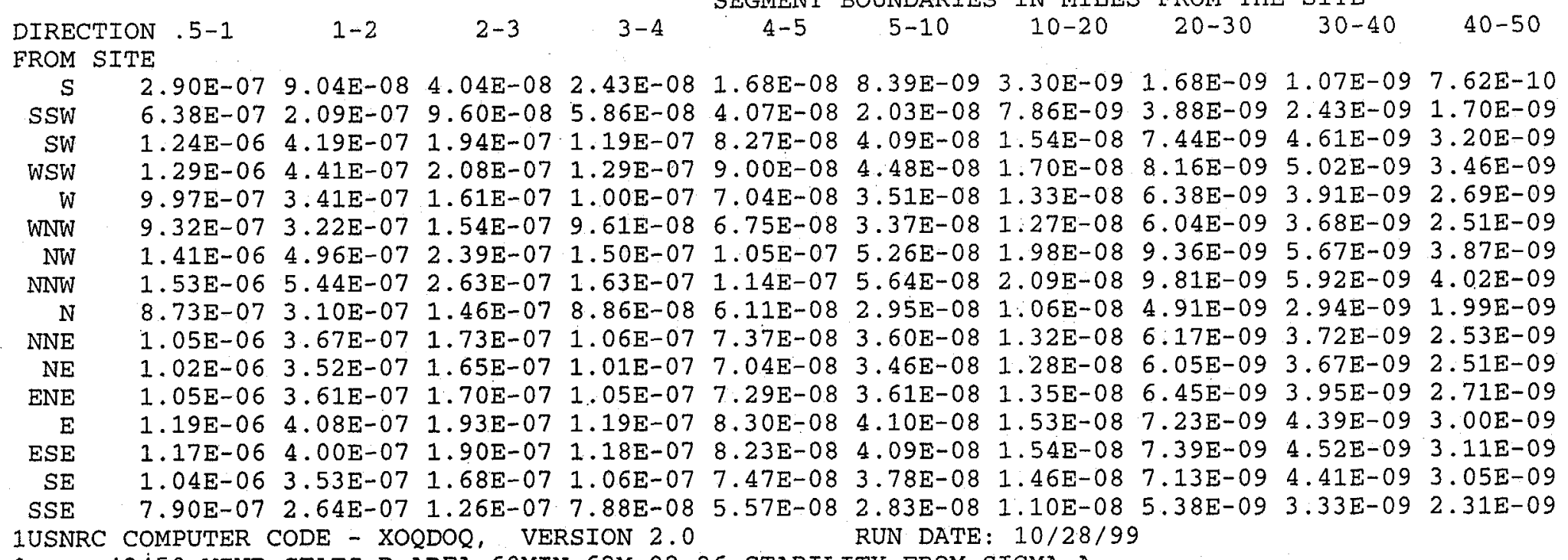

042450 WIND STATS D_AREA 6OMIN 62M $92-96$ STABILITY FROM SIGMA A

8.000 DAY DECAY, DEPLETED

OANNUAL AVERAGE CHI/Q (SEC/METER CUBED)

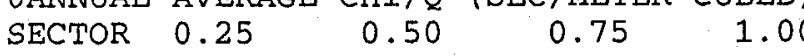

1.50

\section{DIS}

DISTANCE IN MIIUES FROM THE SITE
2.00
2.50
3.00
3.50
4.00

4.50 
$\begin{array}{llllllllllll}S & 2.10 E-06 & 5.25 E-07 & 2.41 E-07 & 1.44 E-07 & 7.46 E-08 & 4.68 E-08 & 3.27 E-08 & 2.45 E-08 & 1.92 E-08 & 1.55 E-08 & 1.29 E-08\end{array}$ SSW $4.14 \mathrm{E}-06 \quad 1.12 \mathrm{E}-06 \quad 5.36 \mathrm{E}-07 \quad 3.27 \mathrm{E}-07 \quad 1.73 \mathrm{E}-07 \quad 1.10 \mathrm{E}-07 \quad 7.77 \mathrm{E}-08$ 5.86E-08 $4.61 \mathrm{E}-08 \quad 3.75 \mathrm{E}-08 \quad 3.12 \mathrm{E}-08$ SW 7.43E-06 2.13E-06 $1.05 E-06 \quad 6.52 E-07 \quad 3.47 E-07 \quad 2.22 E-07 \quad 1.57 E-07 \quad 1.19 E-07 \quad 9.36 E-08 \quad 7.60 E-08 \quad 6.33 E-08$ WSW 7.78E-06 2.22E-06 $1.09 E-06 \quad 6.82 \mathrm{E}-07 \quad 3.66 \mathrm{E}-07 \quad 2.35 \mathrm{E}-07 \quad 1.68 \mathrm{E}-07 \quad 1.28 \mathrm{E}-07 \quad 1.01 \mathrm{E}-07 \quad 8.26 \mathrm{E}-08 \quad 6.90 \mathrm{E}-08$

W 6.05E-06 1.71E-06 8.44E-07 5.25E-07 2.84E-07 $1.83 \mathrm{E}-07 \quad 1.31 \mathrm{E}-07 \quad 9.97 \mathrm{E}-08 \quad 7.91 \mathrm{E}-08 \quad 6.46 \mathrm{E}-08 \quad 5.40 \mathrm{E}-08$ WNW 5.68E-06 $1.60 \mathrm{E}-06 \quad 7.89 \mathrm{E}-07 \quad 4.94 \mathrm{E}-07 \quad 2.69 \mathrm{E}-07 \quad 1.74 \mathrm{E}-07 \quad 1.25 \mathrm{E}-07 \quad 9.54 \mathrm{E}-08 \quad 7.57 \mathrm{E}-08 \quad 6.19 \mathrm{E}-08 \quad 5.18 \mathrm{E}-08$

NW $8.51 \mathrm{E}-06 \quad 2.41 \mathrm{E}-06 \quad 1.20 \mathrm{E}-06 \quad 7.54 \mathrm{E}-07 \quad 4.14 \mathrm{E}-07 \quad 2.70 \mathrm{E}-07 \quad 1.95 \mathrm{E}-07 \quad 1.49 \mathrm{E}-07 \quad 1.18 \mathrm{E}-07 \quad 9.66 \mathrm{E}-08 \quad 8.09 \mathrm{E}-08$ NNW 9.19E-06 2.60E-06 $1.30 \mathrm{E}-06 \quad 8.24 \mathrm{E}-07 \quad 4.56 \mathrm{E}-07 \quad 2.97 \mathrm{E}-07 \quad 2.13 \mathrm{E}-07 \quad 1.62 \mathrm{E}-07 \quad 1.28 \mathrm{E}-07 \quad 1.05 \mathrm{E}-07 \quad 8.74 \mathrm{E}-08$ $\mathrm{N} 5.24 \mathrm{E}-06 \quad 1.46 \mathrm{E}-06 \quad 7.45 \mathrm{E}-07 \quad 4.74 \mathrm{E}-07 \quad 2.59 \mathrm{E}-07 \quad 1.67 \mathrm{E}-07 \quad 1.18 \mathrm{E}-07 \quad 8.88 \mathrm{E}-08 \quad 6.97 \mathrm{E}-08 \quad 5.64 \mathrm{E}-08 \quad 4.68 \mathrm{E}-08$ NNE 6.32E-06 $1.78 E-06 \quad 8.93 E-07 \quad 5.63 E-07 \quad 3.07 E-07 \quad 1.98 E-07 \quad 1.41 E-07 \quad 1.06 E-07 \quad 8.37 E-08 \quad 6.80 E-08 \quad 5.65 E-08$ NE $6.21 \mathrm{E}-06 \quad 1.74 \mathrm{E}-06 \quad 8.66 \mathrm{E}-07 \quad 5.43 \mathrm{E}-07 \quad 2.93 \mathrm{E}-07 \quad 1.89 \mathrm{E}-07 \quad 1.34 \mathrm{E}-07 \quad 1.01 \mathrm{E}-07 \quad 7.99 \mathrm{E}-08 \quad 6.50 \mathrm{E}-08 \quad 5.41 \mathrm{E}-08$ ENE 6.47E-06 1.81E-06 $8.92 E-07 \quad 5.55 E-07 \quad 3.00 E-07 \quad 1.93 E-07 \quad 1.38 E-07 \quad 1.04 E-07 \quad 8.24 E-08 \quad 6.71 E-08 \quad 5.59 E-08$

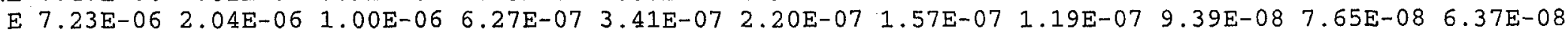
ESE 7.15E-06 2.01E-06 $9.87 E-07 \quad 6.15 E-07 \quad 3.33 E-07 \quad 2.15 E-07 \quad 1.54 E-07 \quad 1.17 E-07 \quad 9.26 E-08 \quad 7.56 E-08 \quad 6.31 E-08$

SE $6.53 E-06 \quad 1.82 E-06 \quad 8.80 E-07 \quad 5.45 E-07 \quad 2.93 E-07 \quad 1.89 E-07 \quad 1.37 E-07 \quad 1.05 E-07 \quad 8.33 E-08 \quad 6.83 E-08 \quad 5.73 E-08$ SSE 5.01E-06 1.38E-06 6.64E-07 4.10E-07 2.19E-07 $1.41 \mathrm{E}-07 \quad 1.02 \mathrm{E}-07 \quad 7.81 \mathrm{E}-08 \quad 6.22 \mathrm{E}-08 \quad 5.10 \mathrm{E}-08 \quad 4.28 \mathrm{E}-08$ OANNUAL AVERAGE CHI/Q (SEC/METER CUBED)

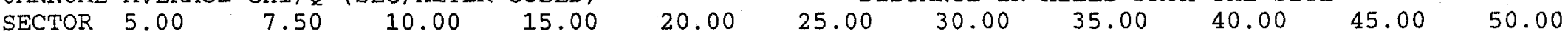

S 1.09E-08 5.98E-09 3.89E-09 2.15E-09 1.42E-09 $1.03 \mathrm{E}-09 \quad 7.90 \mathrm{E}-10 \quad 6.29 \mathrm{E}-10 \quad 5.14 \mathrm{E}-10 \quad 4.30 \mathrm{E}-10 \quad 3.65 \mathrm{E}-10$ SSW 2.65E-08 1.44E-08 9.33E-09 5.05E-09 3.28E-09 2.34E-09 $1.77 \mathrm{E}-09 \quad 1.39 \mathrm{E}-09 \quad 1.12 \mathrm{E}-09 \quad 9.32 \mathrm{E}-10 \quad 7.85 \mathrm{E}-10$ SW $5.37 \mathrm{E}-08 \quad 2.88 \mathrm{E}-08 \quad 1.84 \mathrm{E}-08 \quad 9.79 \mathrm{E}-09 \quad 6.28 \mathrm{E}-09 \quad 4.43 \mathrm{E}-09 \quad 3.31 \mathrm{E}-09 \quad 2.59 \mathrm{E}-09 \quad 2.08 \mathrm{E}-09 \quad 1.71 \mathrm{E}-09 \quad 1.44 \mathrm{E}-09$ WSW 5.87E-08 3.17E-08 2.04E-08 $1.09 \mathrm{E}-08 \quad 6.97 \mathrm{E}-09 \quad 4.90 \mathrm{E}-09 \quad 3.67 \mathrm{E}-09 \quad 2.86 \mathrm{E}-09 \quad 2.29 \mathrm{E}-09 \quad 1.89 \mathrm{E}-09 \quad 1.58 \mathrm{E}-09$

$\mathrm{W} 4.60 \mathrm{E}-08 \quad 2.49 \mathrm{E}-08 \quad 1.60 \mathrm{E}-08 \quad 8.57 \mathrm{E}-09 \quad 5.48 \mathrm{E}-09 \quad 3.86 \mathrm{E}-09 \quad 2.88 \mathrm{E}-09 \quad 2.24 \mathrm{E}-09 \quad 1.80 \mathrm{E}-09 \quad 1.48 \mathrm{E}-09 \quad 1.24 \mathrm{E}-09$ WNW $4.42 E-08 \quad 2.39 E-08 \quad 1.54 E-08 \quad 8.20 E-09 \quad 5.23 E-09 \quad 3.67 E-092.73 E-092.12 E-09 \quad 1.70 E-09 \quad 1.39 E-09 \quad 1.17 E-09$ NW 6.90E-08 3.74E-08 2.40E-08 1.27E-08 8.08E-09 5.65E-09 $4.20 \mathrm{E}-09 \quad 3.25 \mathrm{E}-09 \quad 2.60 \mathrm{E}-09 \quad 2.13 \mathrm{E}-09 \quad 1.78 \mathrm{E}-09$ NNW 7.44E-08 3.99E-08 $2.55 E-08 \quad 1.34 E-08 \quad 8.47 E-09 \quad 5.90 E-09 \quad 4.37 E-09 \quad 3.38 E-09 \quad 2.69 E-09 \quad 2.20 E-09 \quad 1.83 E-09$

N $3.96 \mathrm{E}-08 \quad 2.08 \mathrm{E}-08 \quad 1.31 \mathrm{E}-08 \quad 6.80 \mathrm{E}-09 \quad 4.27 \mathrm{E}-09 \quad 2.96 \mathrm{E}-09 \quad 2.19 \mathrm{E}-09 \quad 1.69 \mathrm{E}-09 \quad 1.34 \mathrm{E}-09 \quad 1.10 \mathrm{E}-09 \quad 9.12 \mathrm{E}-10$ NNE $4.79 \mathrm{E}-08 \quad 2.55 \mathrm{E}-08 \quad 1.62 \mathrm{E}-08 \quad 8.47 \mathrm{E}-09 \quad 5.36 \mathrm{E}-09 \quad 3.74 \mathrm{E}-09 \quad 2.77 \mathrm{E}-09 \quad 2.14 \mathrm{E}-09 \quad 1.71 \mathrm{E}-09 \quad 1.40 \mathrm{E}-09 \quad 1.17 \mathrm{E}-09$

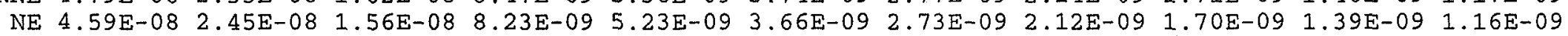
ENE 4.76E-08 2.56E-08 $1.64 \mathrm{E}-08 \quad 8.71 \mathrm{E}-09 \quad 5.57 \mathrm{E}-09 \quad 3.91 \mathrm{E}-09 \quad 2.92 \mathrm{E}-09 \quad 2.27 \mathrm{E}-09 \quad 1.82 \mathrm{E}-09 \quad 1.50 \mathrm{E}-09 \quad 1.25 \mathrm{E}-09$

$\begin{array}{llllllllllll}\mathrm{E} & 5.42 \mathrm{E}-08 & 2.91 \mathrm{E}-08 & 1.86 \mathrm{E}-08 & 9.85 \mathrm{E}-09 & 6.28 \mathrm{E}-09 & 4.40 \mathrm{E}-09 & 3.28 \mathrm{E}-09 & 2.55 \mathrm{E}-09 & 2.04 \mathrm{E}-09 & 1.67 \mathrm{E}-09 & 1.40 \mathrm{E}-09\end{array}$

ESE $5.37 \mathrm{E}-08 \quad 2.90 \mathrm{E}-08 \quad 1.86 \mathrm{E}-08 \quad 9.92 \mathrm{E}-09 \quad 6.34 \mathrm{E}-09 \quad 4.46 \mathrm{E}-09 \quad 3.33 \mathrm{E}-09 \quad 2.59 \mathrm{E}-09 \quad 2.08 \mathrm{E}-09 \quad 1.71 \mathrm{E}-09 \quad 1.43 \mathrm{E}-09$

SE $4.90 E-08 \quad 2.69 E-08 \quad 1.75 E-08 \quad 9.46 E-09 \quad 6.10 E-09 \quad 4.32 E-09 \quad 3.24 E-09 \quad 2.53 E-09 \quad 2.04 E-09 \quad 1.68 E-09 \quad 1.41 E-09$

SSE 3.66E-08 2.02E-08 1.31E-08 7.13E-09 4.61E-09.3.27E-09 2.46E-09 $1.92 \mathrm{E}-09 \quad 1.55 \mathrm{E}-09 \quad 1.28 \mathrm{E}-09 \quad 1.07 \mathrm{E}-09$ OVENT AND BUILDING PARAMETERS:

$\begin{array}{lll}\text { RELEASE HEIGHT } & \text { (METERS) } & 0.00 \\ \text { DIAMETER } & \text { (METERS) } & 0.00 \\ \text { EXIT VELOCITY } & \text { (METERS) } & 0.00\end{array}$

OALL GROUND LEVEL RELEASES.

IUSNRC COMPUTER CODE - XOQDOQ, VERSION 2.0

REP. WIND HEIGHT

BUILDING HEIGHT

BLDG . MIN . CRS . SEC . AREA

HEAT EMISSION RATE

$\begin{array}{lr}\text { (METERS) } & 10.0 \\ \text { (METERS) } & 100.0 \\ \text { (SQ.METERS) } & 0.0 \\ \text { (CAI/SEC) } & 100.0\end{array}$

RUN DATE: $10 / 28 / 99$ 
8.000 DAY DECAY, DEPLETED OCHI/Q (SEC/METER CUBED) FOR EACH SEGMENT

\begin{tabular}{|c|c|c|c|c|c|c|c|c|c|c|c|}
\hline \multirow{3}{*}{\multicolumn{2}{|c|}{$\begin{array}{l}\text { DIRECTION } \\
\text { FROM SITE }\end{array}$}} & $\mathrm{N}$ & 1 & $2-3$ & $3-4$ & $4-5$ & $5-10$ & $10-20$ & $20-30$ & $30-40$ & $40-50$ \\
\hline & & & & & & & & & & & \\
\hline & . & 2 & $7.77 \mathrm{E}$ & $.32 E$ & 1. $93 \mathrm{E}-08$ & $1.29 \mathrm{~F}$ & 6.151 & $2.21 E-09$ & 2.0 & & \\
\hline SW & & & .07 & $7.86 \mathrm{E}-08$ & $4.64 \mathrm{E}-08$ & $13 \mathrm{~F}$ & & $5.22 \mathrm{E}-09$ & & & $5 E-10$ \\
\hline SW & & $1.11 \mathrm{~F}$ & & $1.59 \mathrm{E}-07$ & $9.41 \mathrm{E}-08$ & 08 & -08 & $1.01 \mathrm{E}-08$ & $4.48 E-09$ & $2.60 \mathrm{E}-09$ & 1. $72 \mathrm{E}-09$ \\
\hline WSW & & 1. & & 1. & 07 & & & 08 & & -09 & $9 E-09$ \\
\hline$W$ & & 8 & 07 & 1.32 & & & & & & 9 & 09 \\
\hline WNW & & 8.38 & 07 & 1.2 & 08. & & & 09 & & & \\
\hline NW & & 1. & 07 & 1.96 & $1.19 \mathrm{E}$ & 8. & & -08 & 09 & 3. & 09 \\
\hline NNW & & 1 & & 07 & 1.29 & 8.77 & 8 & -08 & 09 & -09 & -09 \\
\hline $\mathrm{N}$ & & 7 . & & 1.1 & 7. & & & -09 & -09 & 1. & -09 \\
\hline NNE & & 7 & & 1.42 & 8.4 & 5 & & 09 & 09 & 2 . & 09 \\
\hline $\mathrm{NE}$ & & 9 & & 1.36 & 8. & 5 & & & & & -09 \\
\hline ENE & & $9.47 \mathrm{E}-07$ & $3.10 E-07$ & 1.39 & 8.29 & 5.621 & 08 & 09 & 09 & 09 & \\
\hline$E$ & & $1.07 \mathrm{E}$ & $3.51 E-07$ & 1. $58 \mathrm{E}-07$ & $9.44 \mathrm{E}-08$ & $6.40 \mathrm{E}$ & & -08 & & 2. & \\
\hline ESE & & 1.05 & 7 & .55 & 08 & $6.33 \mathrm{E}$ & .08 & -08 & -09 & & -09 \\
\hline$S E$ & & & & & & 5.7 & & & & 2 . & -09 \\
\hline SSE & & $7.10 E-07$ & $7 E-07$ & $3 E-U 7$ & & 4.30 & & & 09 & 09 & $8 E-09$ \\
\hline חרו & & OMPUTER & $D E-X O S$ & & & & & & & & \\
\hline
\end{tabular}

$0 \quad 42450$ WIND STATS D AREA 6OMIN 62M 92-96 STABILITY FROM SIGMA A

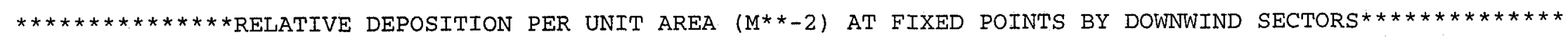
DIRECTION

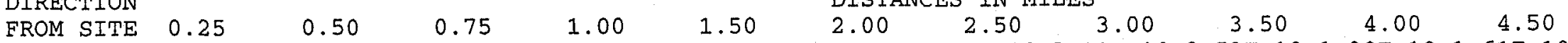
$\begin{array}{llllllllllllllll}S & 2.10 \mathrm{E}-08 & 7.12 \mathrm{E}-09 & 3.65 \mathrm{E}-09 & 2.24 \mathrm{E}-09 & 1.12 \mathrm{E}-09 & 6.78 \mathrm{E}-10 & 4.59 \mathrm{E}-10 & 3.32 \mathrm{E}-10 & 2.53 \mathrm{E}-10 & 1.99 \mathrm{E}-10 & 1.61 \mathrm{E}-10\end{array}$ SSW $\quad 3.33 \mathrm{E}-081.12 \mathrm{E}-08 \quad 5.78 \mathrm{E}-09 \quad 3.55 \mathrm{E}-09 \quad 1.77 \mathrm{E}-09 \quad 1.07 \mathrm{E}-09 \quad 7.25 \mathrm{E}-10 \quad 5.25 \mathrm{E}-10 \quad 4.00 \mathrm{E}-10 \quad 3.15 \mathrm{E}-10 \quad 2.55 \mathrm{E}-10$

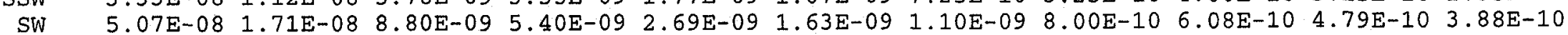
WSW $\quad 4.25 \mathrm{E}-08 \quad 1.44 \mathrm{E}-08 \quad 7.39 \mathrm{E}-09 \quad 4.54 \mathrm{E}-0922.26 \mathrm{E}-09 \quad 1.37 \mathrm{E}-09 \quad 9.27 \mathrm{E}-10 \quad 6.72 \mathrm{E}-10 \quad 5.11 \mathrm{E}-10 \quad 4.03 \mathrm{E}-10 \quad 3.26 \mathrm{E}-10$ W $\quad 2.98 \mathrm{E}-08 \quad 1.01 \mathrm{E}-08 \quad 5.18 \mathrm{E}-09 \quad 3.18 \mathrm{E}-09 \quad 1.59 \mathrm{E}-09 \quad 9.62 \mathrm{E}-10 \quad 6.50 \mathrm{E}-10 \quad 4.71 \mathrm{E}-10 \quad 3.58 \mathrm{E}-10 \quad 2.82 \mathrm{E}-10 \quad 2.29 \mathrm{E}-10$ WNW $\quad 2.65 \mathrm{E}-08 \quad 8.97 \mathrm{E}-09 \quad 4.60 \mathrm{E}-09 \quad 2.83 \mathrm{E}-09 \quad 1.41 \mathrm{E}-09 \quad 8.55 \mathrm{E}-10 \quad 5.78 \mathrm{E}-10 \quad 4.19 \mathrm{E}-10 \quad 3.18 \mathrm{E}-10 \quad 2.51 \mathrm{E}-10 \quad 2.03 \mathrm{E}-10$

NW $\quad 3.66 \mathrm{E}-08 \quad 1.24 \mathrm{E}-08 \quad 6.36 \mathrm{E}-09 \quad 3.90 \mathrm{E}-09 \quad 1.95 \mathrm{E}-09 \quad 1.18 \mathrm{E}-09 \quad 7.98 \mathrm{E}-10 \quad 5.78 \mathrm{E}-10 \quad 4.40 \mathrm{E}-10 \quad 3.46 \mathrm{E}-10 \quad 2.81 \mathrm{E}-10$ NNW $\quad 4.54 \mathrm{E}-08 \quad 1.54 \mathrm{E}-08 \quad 7.88 \mathrm{E}-09 \quad 4.84 \mathrm{E}-092.41 \mathrm{E}-09 \quad 1.46 \mathrm{E}-09 \quad 9.90 \mathrm{E}-10 \quad 7.17 \mathrm{E}-10 \quad 5.45 \mathrm{E}-10 \quad 4.30 \mathrm{E}-10 \quad 3.48 \mathrm{E}-10$ $\mathrm{N} \quad 3.24 \mathrm{E}-08 \quad 1.09 \mathrm{E}-08 \quad 5.62 \mathrm{E}-09 \quad 3.45 \mathrm{E}-09 \quad 1.72 \mathrm{E}-09 \quad 1.04 \mathrm{E}-09 \quad 7.05 \mathrm{E}-10 \quad 5.11 \mathrm{E}-10 \quad 3.89 \mathrm{E}-10 \quad 3.06 \mathrm{E}-10 \quad 2.48 \mathrm{E}-10$ NNE $\quad 3.60 \mathrm{E}-08 \quad 1.22 \mathrm{E}-08 \quad 6.24 \mathrm{E}-09 \quad 3.83 \mathrm{E}-09 \quad 1.91 \mathrm{E}-09 \quad 1.16 \mathrm{E}-09 \quad 7.84 \mathrm{E}-10 \quad 5.68 \mathrm{E}-10 \quad 4.32 \mathrm{E}-10 \quad 3.40 \mathrm{E}-10 \quad 2.75 \mathrm{E}-10$ $\mathrm{NE} \quad 3.73 \mathrm{E}-08 \quad 1.26 \mathrm{E}-08 \quad 6.48 \mathrm{E}-09 \quad 3.98 \mathrm{E}-09 \quad 1.98 \mathrm{E}-09 \quad 1.20 \mathrm{E}-09 \quad 8.14 \mathrm{E}-10 \quad 5.90 \mathrm{E}-10 \quad 4.48 \mathrm{E}-10 \quad 3.53 \mathrm{E}-10 \quad 2.86 \mathrm{E}-10$ 


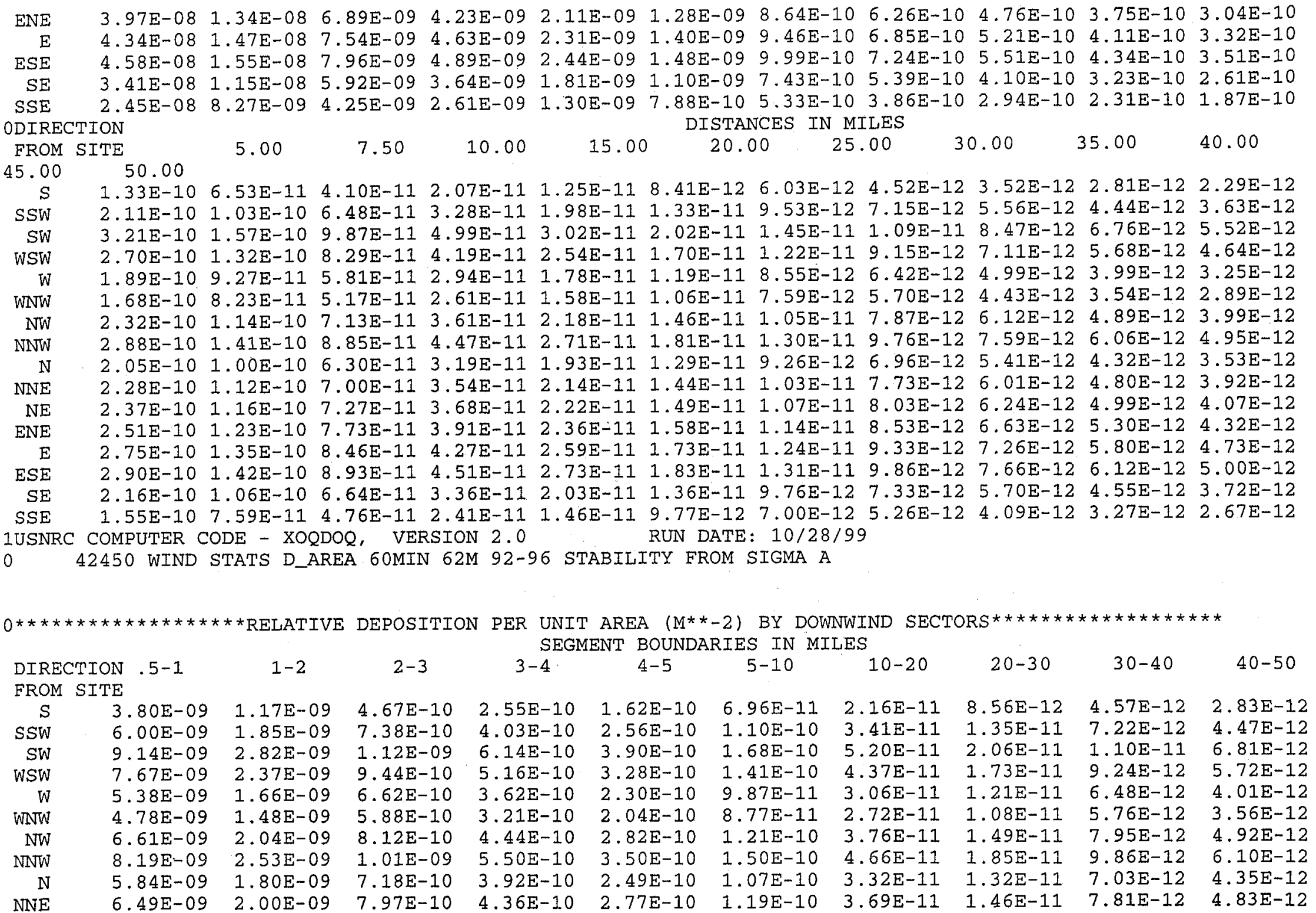




\begin{tabular}{|c|c|c|c|}
\hline $\mathrm{NE}$ & $6.73 E-09$ & $2.08 E-09$ & $8.28 \mathrm{E}-10$ \\
\hline ENE & $7.16 \mathrm{E}-09$ & $2.21 \mathrm{E}-09$ & $80 E-10$ \\
\hline $\mathrm{E}$ & $7.83 \mathrm{E}-09$ & $2.42 \mathrm{E}-09$ & $53 E-10$ \\
\hline ESE & $8.27 \mathrm{E}-09$ & $2.56 \mathrm{E}-09$ & $1.02 E-09$ \\
\hline SF & $6.15 \mathrm{E}-09$ & $1.90 \mathrm{E}-09$ & $7.56 \mathrm{E}-10$ \\
\hline SSE & $4.41 E-09$ & $1.36 \mathrm{E}-09$ & 5. $42 \mathrm{E}-10$ \\
\hline \multicolumn{4}{|c|}{ VENT AND BUILDING PARAMETERS: } \\
\hline & HEIGHT & (METERS) & .00 \\
\hline & DIAME & (METERS & .00 \\
\hline & EXIT & $(\mathbf{N})+2)$ & \\
\hline
\end{tabular}

OALL GROUND LEVEL RELEASES.

IUSNRC COMPUTER CODE - XOODOQ, VERSION 2.0

$\begin{array}{lllllll}4.52 \mathrm{E}-10 & 2.88 \mathrm{E}-10 & 1.24 \mathrm{E}-10 & 3.83 \mathrm{E}-11 & 1.52 \mathrm{E}-11 & 8.11 \mathrm{E}-12 & 5.02 \mathrm{E}-12 \\ 4.81 \mathrm{E}-10 & 3.06 \mathrm{E}-10 & 1.31 \mathrm{E}-10 & 4.07 \mathrm{E}-11 & 1.61 \mathrm{E}-11 & 8.61 \mathrm{E}-12 & 5.33 \mathrm{E}-12 \\ 5.26 \mathrm{E}-10 & 3.34 \mathrm{E}-10 & 1.44 \mathrm{E}-10 & 4.45 \mathrm{E}-11 & 1.76 \mathrm{E}-11 & 9.43 \mathrm{E}-12 & 5.83 \mathrm{E}-12 \\ 5.56 \mathrm{E}-10 & 3.53 \mathrm{E}-10 & 1.52 \mathrm{E}-10 & 4.70 \mathrm{E}-11 & 1.86 \mathrm{E}-11 & 9.96 \mathrm{E}-12 & 6.16 \mathrm{E}-12 \\ 4.13 \mathrm{E}-10 & 2.63 \mathrm{E}-10 & 1.13 \mathrm{E}-10 & 3.50 \mathrm{E}-11 & 1.39 \mathrm{E}-11 & 7.41 \mathrm{E}-12 & 4.58 \mathrm{E}-12 \\ 2.96 \mathrm{E}-10 & 1.88 \mathrm{E}-10 & 8.09 \mathrm{E}-11 & 2.51 \mathrm{E}-11 & 9.95 \mathrm{E}-12 & 5.31 \mathrm{E}-12 & 3.29 \mathrm{E}-12\end{array}$

REP. WIND HEIGHT

BUILDING HEIGHT

BLDG . MIN . CRS . SEC . AREA

HEAT EMISSION RATE

$\begin{array}{lr}\text { (METERS) } & 10.0 \\ \text { (METERS) } & 100.0 \\ \text { (SQ.METERS) } & 0.0 \\ \text { (CAL/SEC) } & 100.0\end{array}$

42450 WIND STATS D_AREA 6OMIN 62M 92-96 STABILITY FROM SIGMA A

SPECIFIC POINTS OF INTEREST

ORELEASE TYPE OF

LOCATION

FROM SITE

DISTANCE

(MILES) (METERS)

1
1
1
1
1
1
1
1
1
1
1
1
1
1
1
1
1
1
1
1
1

$\begin{array}{rll}\text { WNW } & 2.70 & 4341 . \\ \text { WNW } & 2.44 & 3929 . \\ \text { WNW } & 2.30 & 3701 . \\ \text { W } & 2.45 & 3943 . \\ \text { W } & 2.73 & 4398 . \\ \text { W } & 3.03 & 4882 . \\ \text { W } & 3.31 & 5330 . \\ \text { W } & 3.61 & 5802 . \\ \text { W } & 3.89 & 6262 . \\ \text { WNW } & 4.03 & 6485 . \\ \text { WNW } & 4.16 & 6693 . \\ \text { WNW } & 4.42 & 7109 . \\ \text { WNW } & 4.72 & 7592 . \\ \text { WNW } & 5.02 & 8072 . \\ \text { WNW } & 5.31 & 8552 . \\ \text { WNW } & 5.59 & 8993 . \\ \text { WNW. } & 5.69 & 9152 . \\ \text { WNW } & 5.64 & 9073 . \\ \text { WNW } & 5.60 & 9019 . \\ \text { WNW } & 5.50 & 8848 . \\ \text { NW } & 5.46 & 8780 .\end{array}$

\section{$X / Q$}

NO DECAY UNDEPLETED
1. 398E-07

$1.603 \mathrm{E}-07$

1. $741 \mathrm{E}-07$

1. $671 \mathrm{E}-07$

1. $436 \mathrm{E}-07$

1. $242 \mathrm{E}-07$

1. $100 \mathrm{E}-07$

9.778E-08

8. $797 \mathrm{E}-08$

8. $038 E-08$

7. $695 \mathrm{E}-08$

7. $080 \mathrm{E}-08$

$6.467 \mathrm{E}-08$

5. $947 \mathrm{E}-08$

5. $496 \mathrm{E}-08$

5. $132 \mathrm{E}-08$

5. $010 \mathrm{E}-08$

5. $070 \mathrm{E}-08$

5. $111 \mathrm{E}-08$

5. $247 \mathrm{E}-08$

8. $276 \mathrm{E}-08$

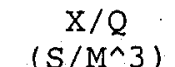

$\left(S / M^{\wedge} 3\right)$ .26 DAY DECAY

UNDEPLETED

1.377 E-07

1. $582 \mathrm{E}-07$

1. $718 \mathrm{E}-07$

1. $649 \mathrm{E}-07$

1. $415 \mathrm{E}-07$

1. $222 \mathrm{E}-07$

1. $080 \mathrm{E}-07$

9. $589 \mathrm{E}-08$

8. $614 \mathrm{E}-08$

$7.857 \mathrm{E}-08$

7. $517 \mathrm{E}-08$

$6.906 \mathrm{E}-08$

$6.297 \mathrm{E}-08$

5. 781E-08

5. $334 \mathrm{E}-08$

4. $972 \mathrm{E}-08$

$4.852 \mathrm{E}-08$

4. $911 \mathrm{E}-08$

$4.952 \mathrm{E}-08$

5. $086 \mathrm{E}-08$

8. $038 \mathrm{E}-08$
$X / Q$

$\left(\mathrm{S} / \mathrm{M}^{\wedge} 3\right)$

$\mathrm{D} / \mathrm{Q}$

8.00 DAY DECAY

DEPLETED

1. 118E-07

1. $297 \mathrm{E}-07$

1. $417 \mathrm{E}-07$

1. $351 \mathrm{E}-07$

1. 147E-07

9. $809 \mathrm{E}-08$

8. 594E-08

7. $561 \mathrm{E}-08$

$6.736 \mathrm{E}-08$

6. $125 \mathrm{E}-08$

5. $839 \mathrm{E}-08$

5. $329 \mathrm{E}-08$

4. $822 \mathrm{E}-08$

4. 396E-08

4. $028 \mathrm{E}-08$

$3.732 \mathrm{E}-08$

3. $634 \mathrm{E}-08$

3. $682 \mathrm{E}-08$

3. $716 \mathrm{E}-08$

3. $825 \mathrm{E}-08$

6. $044 \mathrm{E}-08$

$5.054 E-10$

$6.026 \mathrm{E}-10$

$6.693 \mathrm{E}-10$

6. 740E-10

5. 559E-10

4. $621 \mathrm{E}-10$

3. $954 \mathrm{E}-10$

3. $400 \mathrm{E}-10$

$2.967 \mathrm{E}-10$

2. $476 E-10$

$2.340 E-10$

2. 100E-10

1. $866 \mathrm{E}-10$

1. $671 \mathrm{E}-10$

1. $505 \mathrm{E}-10$

1. 374E-10

1. $331 \mathrm{E}-10$

1. $352 \mathrm{E}-10$

$1.367 \mathrm{E}-10$

1. $415 \mathrm{E}-10$

1. $982 \mathrm{E}-10$ 


$\begin{array}{rrrr}\text { NW } & 5.32 & 8563 . & 8.564 \mathrm{E}-08 \\ \text { NW } & 5.20 & 8368 . & 8.838 \mathrm{E}-08 \\ \text { NW } & 5.15 & 8291 . & 8.951 \mathrm{E}-08 \\ \text { NW } & 5.08 & 8178 . & 9.120 \mathrm{E}-08 \\ \text { NW } & 5.03 & 8092 . & 9.253 \mathrm{E}-08 \\ \text { NW } & 4.99 & 8035 . & 9.343 \mathrm{E}-08 \\ \text { NNW } & 4.97 & 8005 . & 1.012 \mathrm{E}-07 \\ \text { NNW } & 4.98 & 8010 . & 1.012 \mathrm{E}-07 \\ \text { NNW } & 5.00 & 8041 . & 1.006 \mathrm{E}-07 \\ \text { NNW } & 5.29 & 8514 . & 9.294 \mathrm{E}-08 \\ \text { NNW } & 5.59 & 8994 . & 8.612 \mathrm{E}-08 \\ \text { NNW } & 5.78 & 9301 . & 8.220 \mathrm{E}-08 \\ \text { NNW } & 5.91 & 9508 . & 7.972 \mathrm{E}-08 \\ \text { NNW } & 6.10 & 9817 . & 7.626 \mathrm{E}-08 \\ \text { NNW } & 6.37 & 10247 . & 7.185 \mathrm{E}-08 \\ \text { NNW } & 6.53 & 10517 . & 6.930 \mathrm{E}-08 \\ \text { NNW } & 6.70 & 10780 . & 6.697 \mathrm{E}-08 \\ \text { NNW } & 6.88 & 11065 . & 6.459 \mathrm{E}-08 \\ \text { NNW } & 7.17 & 11532 . & 6.099 \mathrm{E}-08 \\ \text { NNW } & 7.46 & 12000 . & 5.772 \mathrm{E}-08 \\ \text { NNW } & 7.68 & 12364 . & 5.538 \mathrm{E}-08 \\ \text { NNW } & 7.91 & 12722 . & 5.323 \mathrm{E}-08 \\ \text { NNW } & 8.07 & 12988 . & 5.173 \mathrm{E}-08 \\ \text { NNW } & 8.34 & 13423 . & 4.942 \mathrm{E}-08 \\ \text { NNW } & 8.37 & 13468 . & 4.919 \mathrm{E}-08 \\ \text { NNW } & 8.47 & 13636 . & 4.836 \mathrm{E}-08 \\ \text { NNW } & 8.76 & 14094 . & 4.620 \mathrm{E}-08 \\ \text { NNW } & 8.90 & 14319 . & 4.520 \mathrm{E}-08 \\ \text { NNW } & 9.22 & 14837 . & 4.303 \mathrm{E}-08 \\ \text { N } & 9.34 & 15028 . & 2.185 \mathrm{E}-08 \\ \mathrm{~N} & 9.55 & 15364 . & 2.117 \mathrm{E}-08 \\ \mathrm{~N} & 9.76 & 15708 . & 2.051 \mathrm{E}-08 \\ \mathrm{~N} & 9.98 & 16060 . & 1.987 \mathrm{E}-08 \\ \mathrm{~N} & 10.22 & 16446 . & 1.921 \mathrm{E}-08 \\ \mathrm{~N} & 10.08 & 16215 . & 1.960 \mathrm{E}-08 \\ \mathrm{~N} & 10.13 & 16298 . & 1.946 \mathrm{E}-08 \\ \mathrm{~N} & 10.28 & 16549 . & 1.904 \mathrm{E}-08 \\ \mathrm{~N} & 10.27 & 16533 . & 1.907 \mathrm{E}-08 \\ \mathrm{~N} & 10.53 & 16951 . & 1.840 \mathrm{E}-08 \\ \mathrm{~N} & 10.79 & 17372 . & 1.777 \mathrm{E}-08 \\ \mathrm{~N} & 11.07 & 17813 . & 1.715 \mathrm{E}-08 \\ \mathrm{~N} & 11.25 & 18102 . & 1.676 \mathrm{E}-08 \\ & & & \end{array}$

$8.324 E-08$
$8.596 E-08$
$8.707 E-08$
$8.876 E-08$
$9.007 E-08$
$9.097 E-08$
$9.873 E-08$
$9.864 E-08$
$9.810 E-08$
$9.048 E-08$
$8.371 E-08$
$7.982 E-08$
$7.737 E-08$
$7.394 E-08$
$6.957 E-08$
$6.704 E-08$
$6.473 E-08$
$6.237 E-08$
$5.881 E-08$
$5.558 E-08$
$5.326 E-08$
$5.114 E-08$
$4.965 E-08$
$4.737 E-08$
$4.715 E-08$
$4.632 E-08$
$4.419 E-08$
$4.320 E-08$
$4.106 E-08$
$2.080 E-08$
$2.013 E-08$
$1.948 E-08$
$1.885 E-08$
$1.820 E-08$
$1.859 E-08$
$1.845 E-08$
$1.803 E-08$
$1.806 E-08$
$1.740 E-08$
$1.678 E-08$
$1.617 E-08$
$1.579 E-08$
6

\begin{tabular}{|c|}
\hline \\
\hline \\
\hline \\
\hline \\
\hline \\
\hline \\
\hline \\
\hline \\
\hline \\
\hline \\
\hline \\
\hline \\
\hline \\
\hline \\
\hline \\
\hline \\
\hline \\
\hline 3 \\
\hline \\
\hline \\
\hline \\
\hline \\
\hline \\
\hline \\
\hline \\
\hline \\
\hline \\
\hline \\
\hline
\end{tabular}

$\begin{array}{ll}6.278 \mathrm{E}-08 & 2.074 \mathrm{E}-10 \\ 6.501 \mathrm{E}-08 & 2.162 \mathrm{E}-10 \\ 6.593 \mathrm{E}-08 & 2.198 \mathrm{E}-10 \\ 6.731 \mathrm{E}-08 & 2.254 \mathrm{E}-10 \\ 6.840 \mathrm{E}-08 & 2.297 \mathrm{E}-10 \\ 6.913 \mathrm{E}-08 & 2.326 \mathrm{E}-10 \\ 7.499 \mathrm{E}-08 & 2.904 \mathrm{E}-10 \\ 7.491 \mathrm{E}-08 & 2.901 \mathrm{E}-10 \\ 7.447 \mathrm{E}-08 & 2.881 \mathrm{E}-10 \\ 6.821 \mathrm{E}-08 & 2.598 \mathrm{E}-10 \\ 6.269 \mathrm{E}-08 & 2.353 \mathrm{E}-10 \\ 5.953 \mathrm{E}-08 & 2.214 \mathrm{E}-10 \\ 5.754 \mathrm{E}-08 & 2.127 \mathrm{E}-10 \\ 5.476 \mathrm{E}-08 & 2.007 \mathrm{E}-10 \\ 5.147 \mathrm{E}-08 & 1.826 \mathrm{E}-10 \\ 4.944 \mathrm{E}-08 & 1.753 \mathrm{E}-10 \\ 4.759 \mathrm{E}-08 & 1.686 \mathrm{E}-10 \\ 4.570 \mathrm{E}-08 & 1.618 \mathrm{E}-10 \\ 4.286 \mathrm{E}-08 & 1.516 \mathrm{E}-10 \\ 4.029 \mathrm{E}-08 & 1.423 \mathrm{E}-10 \\ 3.846 \mathrm{E}-08 & 1.357 \mathrm{E}-10 \\ 3.679 \mathrm{E}-08 & 1.296 \mathrm{E}-10 \\ 3.562 \mathrm{E}-08 & 1.254 \mathrm{E}-10 \\ 3.384 \mathrm{E}-08 & 1.189 \mathrm{E}-10 \\ 3.366 \mathrm{E}-08 & 1.183 \mathrm{E}-10 \\ 3.302 \mathrm{E}-08 & 1.159 \mathrm{E}-10 \\ 3.135 \mathrm{E}-08 & 1.099 \mathrm{E}-10 \\ 3.059 \mathrm{E}-08 & 1.071 \mathrm{E}-10 \\ 2.893 \mathrm{E}-08 & 1.011 \mathrm{E}-10 \\ 1.465 \mathrm{E}-08 & 7.052 \mathrm{E}-11 \\ 1.413 \mathrm{E}-08 & 6.802 \mathrm{E}-11 \\ 1.364 \mathrm{E}-08 & 6.559 \mathrm{E}-11 \\ 1.316 \mathrm{E}-08 & 6.325 \mathrm{E}-11 \\ 1.266 \mathrm{E}-08 & 6.082 \mathrm{E}-11 \\ 1.296 \mathrm{E}-08 & 6.225 \mathrm{E}-11 \\ 1.285 \mathrm{E}-08 & 6.173 \mathrm{E}-11 \\ 1.253 \mathrm{E}-08 & 6.019 \mathrm{E}-11 \\ 1.255 \mathrm{E}-08 & 6.029 \mathrm{E}-11 \\ 1.205 \mathrm{E}-08 & 5.785 \mathrm{E}-11 \\ 1.159 \mathrm{E}-08 & 5.555 \mathrm{E}-11 \\ 1.112 \mathrm{E}-08 & 5.328 \mathrm{E}-11 \\ 1.084 \mathrm{E}-08 & 5.187 \mathrm{E}-11 \\ & \end{array}$




\begin{tabular}{|c|c|c|}
\hline $\mathrm{N}$ & 11.21 & 18048 \\
\hline $\mathrm{N}$ & 11.45 & 18420 . \\
\hline $\mathrm{N}$ & 11.49 & 18495 \\
\hline $\mathrm{N}$ & 11.60 & 18675 \\
\hline $\mathrm{N}$ & 11.86 & 19079. \\
\hline $\mathrm{N}$ & 11.88 & 19114. \\
\hline $\mathrm{N}$ & 12.09 & 19454 . \\
\hline $\mathrm{N}$ & 12.31 & 19817 \\
\hline $\mathbf{N}$ & 12.45 & 20041 \\
\hline $\mathrm{N}$ & 12.63 & 20327. \\
\hline $\mathrm{N}$ & 12.81 & 20617 \\
\hline NNE & 12.92 & 20800 \\
\hline NNE & 13.04 & 20980 \\
\hline NNE & 13.27 & 21353 . \\
\hline NNE & 13.33 & 21456 . \\
\hline NNE & 13.39 & 21545 \\
\hline NNE & 13.39 & 21548 \\
\hline NNE & 13.55 & 21807 . \\
\hline NNE & 13.85 & 22285 . \\
\hline NNE & 14.12 & 22724 \\
\hline NNE & 14.23 & 22893 \\
\hline NNE & 14.37 & 23122 . \\
\hline NNE & 14.29 & $23003^{\prime \prime}$ \\
\hline NNE & 14.58 & 23471 \\
\hline NNE & 14.76 & 23757 . \\
\hline NNE & 14.90 & 23975 . \\
\hline NNE & 15.04 & 24201 . \\
\hline NNE & 15.18 & 24434 . \\
\hline NNE & 15.33 & 24675 . \\
\hline NNE & 15.49 & 24924 \\
\hline NNE & 15.65 & 25179 \\
\hline NNE & 15.81 & 25441 . \\
\hline NNE & 15.61 & 25126 . \\
\hline NNE & 15.62 & 25141 \\
\hline $\mathrm{NNE}$ & 15.79 & 25414 \\
\hline NNE & 15.90 & 25591. \\
\hline NNE & 16.00 & 25755 \\
\hline NNE & 16.12 & 25946 \\
\hline $\mathrm{NE}$ & 16.37 & 26344 . \\
\hline $\mathrm{NE}$ & 16.62 & 26740 . \\
\hline $\mathrm{NE}$ & 16.89 & 27188 \\
\hline $\mathrm{NE}$ & 17.11 & 27530 \\
\hline
\end{tabular}

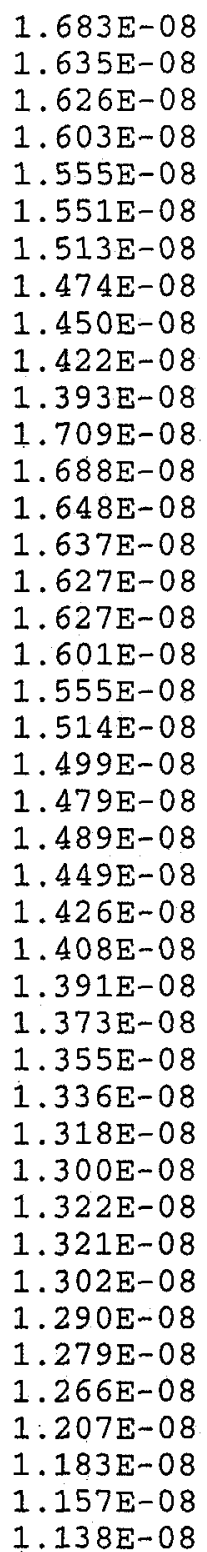

1. $683 \mathrm{E}-08$

1. $586 \mathrm{E}-08$

1. $539 \mathrm{E}-08$

1. $530 \mathrm{E}-08$

1. $508 \mathrm{E}-08$

1. $461 \mathrm{E}-08$

1. $457 \mathrm{E}-08$

1. $419 \mathrm{E}-08$

1. $381 E-08$

1. $358 \mathrm{E}-08$

1.329E-08

1. $302 \mathrm{E}-08$

1. $591 \mathrm{E}-08$

$1.571 \mathrm{E}-08$

$1.531 \mathrm{E}-08$

1. $520 \mathrm{E}-08$

1. $511 \mathrm{E}-08$

1. $511 \mathrm{E}-08$

1. $485 \mathrm{E}-08$

1. $440 \mathrm{E}-08$

1. $400 \mathrm{E}-08$

1. $386 \mathrm{E}-08$

1. $366 \mathrm{E}-08$

1.376E-08

1. $337 \mathrm{E}-08$

1. $314 \mathrm{E}-08$

1.297E-08

1. $280 \mathrm{E}-08$

1. $262 \mathrm{E}-08$

1. $245 \mathrm{E}-08$

1. $227 \mathrm{E}-08$

1. 209E-08

1. 191E-08

1. $213 \mathrm{E}-08$

1. $212 \mathrm{E}-08$

1. $193 \mathrm{E}-08$

1. $181 \mathrm{E}-08$

1. $170 \mathrm{E}-08$

1. $158 \mathrm{E}-08$

1. $102 \mathrm{E}-08$

1. $079 \mathrm{E}-08$

$1.053 \mathrm{E}-08$

1. $035 \mathrm{E}-08$
$1.089 E-08$

1. $054 \mathrm{E}-08$

1. $047 \mathrm{E}-08$

1. $030 \mathrm{E}-08$

$9.950 \mathrm{E}-09$

$9.920 \mathrm{E}-09$

9. $640 \mathrm{E}-09$

9. $354 \mathrm{E}-09$

9. $184 \mathrm{E}-09$

8. $974 \mathrm{E}-09$

$8.769 \mathrm{E}-09$

1. $073 \mathrm{E}-08$

1. $058 \mathrm{E}-08$

1. $028 \mathrm{E}-08$

1. $020 \mathrm{E}-08$

$1.014 \mathrm{E}-08$

1. $014 \mathrm{E}-08$

9. $947 \mathrm{E}-09$

9. $613 \mathrm{E}-09$

9. $322 \mathrm{E}-09$

9. $214 \mathrm{E}-09$

9. $070 \mathrm{E}-09$

9.144E-09

8. 858E-09

8. 691E-09

8. 566E-09

8. $440 E-09$

8. $313 E-09$

8.185E-09

8. 056E-09

7. $927 \mathrm{E}-09$

7. $798 \mathrm{E}-09$

7. $954 \mathrm{E}-09$

7. $946 E-09$

7. 811E-09

$7.726 \mathrm{E}-09$

$7.648 \mathrm{E}-09$

7. 559E-09

7.179E-09

$7.013 E-09$

$6.833 \mathrm{E}-09$

$6.700 \mathrm{E}-09$
5. 213E-11

$5.038 \mathrm{E}-11$

$5.004 \mathrm{E}-11$

4. $924 \mathrm{E}-11$

4.751E-11

4. $736 \mathrm{E}-11$

$4.598 \mathrm{E}-11$

4. $457 \mathrm{E}-11$

4. $373 \mathrm{E}-11$

4. $270 \mathrm{E}-11$

4. 169 E-11

4. $564 \mathrm{E}-11$

$4.498 \mathrm{E}-11$

4. $366 \mathrm{E}-11$

4. $330 \mathrm{E}-11$

4. 300E-11

4. $299 \mathrm{E}-11$

4. $213 \mathrm{E}-11$

4. 060E-11

3. $927 \mathrm{E}-11$

3. $878 \mathrm{E}-11$

3. $812 \mathrm{E}-11$

3. $846 \mathrm{E}-11$

3. $715 \mathrm{E}-11$

3. $639 \mathrm{E}-11$

3. $582 \mathrm{E}-11$

3. $525 \mathrm{E}-11$

3. $467 \mathrm{E}-11$

3. $409 \mathrm{E}-11$

3. $351 E-11$

3. $292 \mathrm{E}-11$

3. $234 \mathrm{E}-11$

3. $304 \mathrm{E}-11$

3. 301E-11

3. 240E-11

3. $201 \mathrm{E}-11$

3. $166 \mathrm{E}-11$

3. $126 \mathrm{E}-11$

3. $161 \mathrm{E}-11$

3. $080 \mathrm{E}-11$

$2.993 \mathrm{E}-11$

$2.928 \mathrm{E}-11$ 


$\begin{array}{lllll}N E & 17.11 & 27540 . & 1.138 \mathrm{E}-08 & 1.034 \mathrm{E}-08 \\ \mathrm{NE} & 17.36 & 27942 . & 1.116 \mathrm{E}-08 & 1.013 \mathrm{E}-08 \\ \mathrm{NE} & 17.45 & 28080 . & 1.109 \mathrm{E}-08 & 1.006 \mathrm{E}-08 \\ \mathrm{NE} & 17.27 & 27793 . & 1.124 \mathrm{E}-08 & 1.021 \mathrm{E}-08 \\ \mathrm{NE} & 17.52 & 28190 . & 1.103 \mathrm{E}-08 & 1.001 \mathrm{E}-08 \\ \mathrm{NE} & 17.60 & 28320 . & 1.096 \mathrm{E}-08 & 9.940 \mathrm{E}-09 \\ \mathrm{NE} & 17.62 & 28349 . & 1.095 \mathrm{E}-08 & 9.926 \mathrm{E}-09 \\ \mathrm{NE} & 17.62 & 28361 . & 1.094 \mathrm{E}-08 & 9.920 \mathrm{E}-09 \\ \mathrm{NE} & 17.83 & 28689 . & 1.078 \mathrm{E}-08 & 9.758 \mathrm{E}-09 \\ \mathrm{NE} & 18.00 & 28962 . & 1.064 \mathrm{E}-08 & 9.627 \mathrm{E}-09 \\ \mathrm{NE} & 17.90 & 28811 . & 1.072 \mathrm{E}-08 & 9.699 \mathrm{E}-09 \\ \mathrm{NE} & 17.84 & 28703 . & 1.077 \mathrm{E}-08 & 9.752 \mathrm{E}-09 \\ \mathrm{NE} & 17.84 & 28711 . & 1.077 \mathrm{E}-08 & 9.748 \mathrm{E}-09 \\ \mathrm{NE} & 17.91 & 28829 . & 1.071 \mathrm{E}-08 & 9.691 \mathrm{E}-09 \\ \mathrm{NE} & 17.99 & 28956 . & 1.065 \mathrm{E}-08 & 9.630 \mathrm{E}-09 \\ \mathrm{NE} & 18.15 & 29212 . & 1.052 \mathrm{E}-08 & 9.510 \mathrm{E}-09 \\ \mathrm{NE} & 18.37 & 29565 . & 1.036 \mathrm{E}-08 & 9.349 \mathrm{E}-09 \\ \mathrm{NE} & 18.17 & 29237 . & 1.051 \mathrm{E}-08 & 9.499 \mathrm{E}-09 \\ \mathrm{NE} & 18.10 & 29130 . & 1.056 \mathrm{E}-08 & 9.548 \mathrm{E}-09 \\ \mathrm{NE} & 18.07 & 29078 . & 1.059 \mathrm{E}-08 & 9.573 \mathrm{E}-09 \\ \mathrm{NE} & 17.95 & 28890 . & 1.068 \mathrm{E}-08 & 9.662 \mathrm{E}-09 \\ \mathrm{NE} & 18.09 & 29107 . & 1.057 \mathrm{E}-08 & 9.559 \mathrm{E}-09 \\ \mathrm{NE} & 18.08 & 29105 . & 1.057 \mathrm{E}-08 & 9.560 \mathrm{E}-09 \\ \mathrm{NE} & 18.11 & 29147 . & 1.055 \mathrm{E}-08 & 9.540 \mathrm{E}-09 \\ \mathrm{NE} & 17.82 & 28671 . & 1.079 \mathrm{E}-08 & 9.767 \mathrm{E}-09 \\ \mathrm{NE} & 17.82 & 28680 . & 1.078 \mathrm{E}-08 & 9.763 \mathrm{E}-09 \\ \mathrm{ENE} & 17.89 & 28786 . & 1.139 \mathrm{E}-08 & 1.031 \mathrm{E}-08 \\ \mathrm{ENE} & 17.88 & 28773 . & 1.139 \mathrm{E}-08 & 1.032 \mathrm{E}-08 \\ \mathrm{ENE} & 18.01 & 28983 . & 1.128 \mathrm{E}-08 & 1.021 \mathrm{E}-08 \\ \mathrm{ENE} & 18.14 & 29200 . & 1.117 \mathrm{E}-08 & 1.011 \mathrm{E}-08 \\ \mathrm{ENE} & 17.99 & 28957 . & 1.130 \mathrm{E}-08 & 1.023 \mathrm{E}-08 \\ \mathrm{ENE} & 17.80 & 28649 . & 1.146 \mathrm{E}-08 & 1.038 \mathrm{E}-08 \\ \mathrm{ENE} & 17.64 & 28386 . & 1.160 \mathrm{E}-08 & 1.052 \mathrm{E}-08 \\ \mathrm{ENE} & 17.59 & 28310 . & 1.164 \mathrm{E}-08 & 1.056 \mathrm{E}-08 \\ \mathrm{ENE} & 17.43 & 28046 . & 1.178 \mathrm{E}-08 & 1.070 \mathrm{E}-08 \\ \mathrm{ENE} & 17.27 & 27793 . & 1.192 \mathrm{E}-08 & 1.083 \mathrm{E}-08 \\ \mathrm{ENE} & 17.18 & 27647 . & 1.200 \mathrm{E}-08 & 1.091 \mathrm{E}-08 \\ \mathrm{ENE} & 17.08 & 27491 . & 1.209 \mathrm{E}-08 & 1.100 \mathrm{E}-08 \\ \mathrm{ENE} & 16.85 & 27117 . & 1.231 \mathrm{E}-08 & 1.122 \mathrm{E}-08 \\ \mathrm{ENE} & 16.78 & 27012 . & 1.238 \mathrm{E}-08 & 1.128 \mathrm{E}-08 \\ \mathrm{ENE} & 16.76 & 26973 . & 1.240 \mathrm{E}-08 & 1.130 \mathrm{E}-08 \\ \mathrm{ENE} & 16.76 & 26966 . & 1.240 \mathrm{E}-08 & 1.130 \mathrm{E}-08\end{array}$

$\begin{array}{ll}6.696 \mathrm{E}-09 & 2.926 \mathrm{E}-11 \\ 6.545 \mathrm{E}-09 & 2.853 \mathrm{E}-11 \\ 6.494 \mathrm{E}-09 & 2.829 \mathrm{E}-11 \\ 6.600 \mathrm{E}-09 & 2.880 \mathrm{E}-11 \\ 6.454 \mathrm{E}-09 & 2.810 \mathrm{E}-11 \\ 6.408 \mathrm{E}-09 & 2.787 \mathrm{E}-11 \\ 6.397 \mathrm{E}-09 & 2.782 \mathrm{E}-11 \\ 6.393 \mathrm{E}-09 & 2.780 \mathrm{E}-11 \\ 6.278 \mathrm{E}-09 & 2.725 \mathrm{E}-11 \\ 6.185 \mathrm{E}-09 & 2.680 \mathrm{E}-11 \\ 6.237 \mathrm{E}-09 & 2.704 \mathrm{E}-11 \\ 6.274 \mathrm{E}-09 & 2.722 \mathrm{E}-11 \\ 6.271 \mathrm{E}-09 & 2.721 \mathrm{E}-11 \\ 6.230 \mathrm{E}-09 & 2.701 \mathrm{E}-11 \\ 6.187 \mathrm{E}-09 & 2.681 \mathrm{E}-11 \\ 6.102 \mathrm{E}-09 & 2.640 \mathrm{E}-11 \\ 5.987 \mathrm{E}-09 & 2.585 \mathrm{E}-11 \\ 6.094 \mathrm{E}-09 & 2.636 \mathrm{E}-11 \\ 6.129 \mathrm{E}-09 & 2.653 \mathrm{E}-11 \\ 6.147 \mathrm{E}-09 & 2.661 \mathrm{E}-11 \\ 6.210 \mathrm{E}-09 & 2.691 \mathrm{E}-11 \\ 6.137 \mathrm{E}-09 & 2.656 \mathrm{E}-11 \\ 6.138 \mathrm{E}-09 & 2.657 \mathrm{E}-11 \\ 6.124 \mathrm{E}-09 & 2.650 \mathrm{E}-11 \\ 6.285 \mathrm{E}-09 & 2.728 \mathrm{E}-11 \\ 6.282 \mathrm{E}-09 & 2.726 \mathrm{E}-11 \\ 6.628 \mathrm{E}-09 & 2.878 \mathrm{E}-11 \\ 6.633 \mathrm{E}-09 & 2.880 \mathrm{E}-11 \\ 6.558 \mathrm{E}-09 & 2.844 \mathrm{E}-11 \\ 6.482 \mathrm{E}-09 & 2.807 \mathrm{E}-11 \\ 6.567 \mathrm{E}-09 & 2.848 \mathrm{E}-11 \\ 6.678 \mathrm{E}-09 & 2.902 \mathrm{E}-11 \\ 6.775 \mathrm{E}-09 & 2.949 \mathrm{E}-11 \\ 6.803 \mathrm{E}-09 & 2.963 \mathrm{E}-11 \\ 6.903 \mathrm{E}-09 & 3.012 \mathrm{E}-11 \\ 7.001 \mathrm{E}-09 & 3.060 \mathrm{E}-11 \\ 7.059 \mathrm{E}-09 & 3.088 \mathrm{E}-11 \\ 7.121 \mathrm{E}-09 & 3.119 \mathrm{E}-11 \\ 7.275 \mathrm{E}-09 & 3.194 \mathrm{E}-11 \\ 7.319 \mathrm{E}-09 & 3.216 \mathrm{E}-11 \\ 7.335 \mathrm{E}-09 & 3.224 \mathrm{E}-11 \\ 7.338 \mathrm{E}-09 & 3.225 \mathrm{E}-11 \\ & \end{array}$




$\begin{array}{lllll}\text { ENE } & 16.54 & 26614 . & 1.262 \mathrm{E}-08 & 1.151 \mathrm{E}-08 \\ \mathrm{ENE} & 16.25 & 26154 . & 1.291 \mathrm{E}-08 & 1.180 \mathrm{E}-08 \\ \text { ENE } & 15.97 & 25694 . & 1.322 \mathrm{E}-08 & 1.210 \mathrm{E}-08 \\ \mathrm{ENE} & 15.75 & 25352 . & 1.345 \mathrm{E}-08 & 1.233 \mathrm{E}-08 \\ \mathrm{ENE} & 15.63 & 25161 . & 1.359 \mathrm{E}-08 & 1.246 \mathrm{E}-08 \\ \mathrm{ENE} & 15.52 & 24978 . & 1.372 \mathrm{E}-08 & 1.258 \mathrm{E}-08 \\ \mathrm{ENE} & 15.41 & 24804 . & 1.385 \mathrm{E}-08 & 1.271 \mathrm{E}-08 \\ \mathrm{ENE} & 15.30 & 24630 . & 1.397 \mathrm{E}-08 & 1.283 \mathrm{E}-08 \\ \mathrm{ENE} & 15.08 & 24266 . & 1.425 \mathrm{E}-08 & 1.310 \mathrm{E}-08 \\ \mathrm{ENE} & 14.86 & 23914 . & 1.453 \mathrm{E}-08 & 1.338 \mathrm{E}-08 \\ \mathrm{ENE} & 14.64 & 23565 . & 1.481 \mathrm{E}-08 & 1.365 \mathrm{E}-08 \\ \mathrm{ENE} & 14.42 & 23212 . & 1.511 \mathrm{E}-08 & 1.394 \mathrm{E}-08 \\ \mathrm{ENE} & 14.26 & 22951 . & 1.534 \mathrm{E}-08 & 1.417 \mathrm{E}-08 \\ \mathrm{ENE} & 14.14 & 22754 . & 1.551 \mathrm{E}-08 & 1.434 \mathrm{E}-08 \\ \mathrm{E} & 14.13 & 22741 . & 1.758 \mathrm{E}-08 & 1.619 \mathrm{E}-08 \\ \mathrm{E} & 14.21 & 22861 . & 1.746 \mathrm{E}-08 & 1.607 \mathrm{E}-08 \\ \mathrm{E} & 14.51 & 23346 . & 1.698 \mathrm{E}-08 & 1.560 \mathrm{E}-08 \\ \mathrm{E} & 14.81 & 23829 . & 1.653 \mathrm{E}-08 & 1.516 \mathrm{E}-08 \\ \mathrm{E} & 15.10 & 24308 . & 1.610 \mathrm{E}-08 & 1.474 \mathrm{E}-08 \\ \mathrm{E} & 15.40 & 24788 . & 1.569 \mathrm{E}-08 & 1.434 \mathrm{E}-08 \\ \mathrm{E} & 15.65 & 25186 . & 1.536 \mathrm{E}-08 & 1.402 \mathrm{E}-08 \\ \mathrm{E} & 15.60 & 25103 . & 1.543 \mathrm{E}-08 & 1.408 \mathrm{E}-08 \\ \mathrm{E} & 15.44 & 24845 . & 1.564 \mathrm{E}-08 & 1.429 \mathrm{E}-08 \\ \mathrm{E} & 15.33 & 24675 . & 1.578 \mathrm{E}-08 & 1.443 \mathrm{E}-08 \\ \mathrm{E} & 15.25 & 24543 . & 1.590 \mathrm{E}-08 & 1.454 \mathrm{E}-08 \\ \mathrm{E} & 15.20 & 24456 . & 1.597 \mathrm{E}-08 & 1.461 \mathrm{E}-08 \\ \mathrm{E} & 15.47 & 24903 . & 1.559 \mathrm{E}-08 & 1.424 \mathrm{E}-08 \\ \mathrm{E} & 15.30 & 24618 . & 1.583 \mathrm{E}-08 & 1.448 \mathrm{E}-08 \\ \mathrm{E} & 15.11 & 24325 . & 1.608 \mathrm{E}-08 & 1.472 \mathrm{E}-08 \\ \mathrm{E} & 15.16 & 24401 . & 1.602 \mathrm{E}-08 & 1.466 \mathrm{E}-08 \\ \mathrm{E} & 15.11 & 24318 . & 1.609 \mathrm{E}-08 & 1.473 \mathrm{E}-08 \\ \mathrm{E} & 15.22 & 24499 . & 1.593 \mathrm{E}-08 & 1.457 \mathrm{E}-08 \\ \mathrm{E} & 15.14 & 24362 . & 1.605 \mathrm{E}-08 & 1.469 \mathrm{E}-08 \\ \mathrm{E} & 14.91 & 23999 . & 1.637 \mathrm{E}-08 & 1.500 \mathrm{E}-08 \\ \mathrm{E} & 14.92 & 24016 . & 1.636 \mathrm{E}-08 & 1.499 \mathrm{E}-08 \\ \mathrm{E} & 14.99 & 24120 . & 1.627 \mathrm{E}-08 & 1.490 \mathrm{E}-08 \\ \mathrm{E} & 15.04 & 24204 . & 1.619 \mathrm{E}-08 & 1.483 \mathrm{E}-08 \\ \mathrm{E} & 15.08 & 24272 . & 1.613 \mathrm{E}-08 & 1.477 \mathrm{E}-08 \\ \mathrm{E} & 15.21 & 24486 . & 1.594 \mathrm{E}-08 & 1.459 \mathrm{E}-08 \\ \mathrm{E} & 15.39 & 24770 . & 1.570 \mathrm{E}-08 & 1.435 \mathrm{E}-08 \\ \mathrm{E} & 15.63 & 25149 . & 1.539 \mathrm{E}-08 & 1.405 \mathrm{E}-08 \\ \mathrm{E} & 15.90 & 25589 . & 1.504 \mathrm{E}-08 & 1.371 \mathrm{E}-08\end{array}$

$\begin{array}{ll}7.490 \mathrm{E}-09 & 3.300 \mathrm{E}-11 \\ 7.695 \mathrm{E}-09 & 3.401 \mathrm{E}-11 \\ 7.910 \mathrm{E}-09 & 3.507 \mathrm{E}-11 \\ 8.076 \mathrm{E}-09 & 3.590 \mathrm{E}-11 \\ 8.171 \mathrm{E}-09 & 3.637 \mathrm{E}-11 \\ 8.264 \mathrm{E}-09 & 3.683 \mathrm{E}-11 \\ 8.354 \mathrm{E}-09 & 3.728 \mathrm{E}-11 \\ 8.446 \mathrm{E}-09 & 3.773 \mathrm{E}-11 \\ 8.642 \mathrm{E}-09 & 3.871 \mathrm{E}-11 \\ 8.840 \mathrm{E}-09 & 3.969 \mathrm{E}-11 \\ 9.043 \mathrm{E}-09 & 4.071 \mathrm{E}-11 \\ 9.256 \mathrm{E}-09 & 4.178 \mathrm{E}-11 \\ 9.419 \mathrm{E}-09 & 4.259 \mathrm{E}-11 \\ 9.545 \mathrm{E}-09 & 4.322 \mathrm{E}-11 \\ 1.081 \mathrm{E}-08 & 4.734 \mathrm{E}-11 \\ 1.072 \mathrm{E}-08 & 4.692 \mathrm{E}-11 \\ 1.038 \mathrm{E}-08 & 4.526 \mathrm{E}-11 \\ 1.005 \mathrm{E}-08 & 4.370 \mathrm{E}-11 \\ 9.747 \mathrm{E}-09 & 4.223 \mathrm{E}-11 \\ 9.455 \mathrm{E}-09 & 4.083 \mathrm{E}-11 \\ 9.224 \mathrm{E}-09 & 3.973 \mathrm{E}-11 \\ 9.271 \mathrm{E}-09 & 3.995 \mathrm{E}-11 \\ 9.421 \mathrm{E}-09 & 4.067 \mathrm{E}-11 \\ 9.523 \mathrm{E}-09 & 4.116 \mathrm{E}-11 \\ 9.602 \mathrm{E}-09 & 4.154 \mathrm{E}-11 \\ 9.655 \mathrm{E}-09 & 4.179 \mathrm{E}-11 \\ 9.387 \mathrm{E}-09 & 4.051 \mathrm{E}-11 \\ 9.557 \mathrm{E}-09 & 4.132 \mathrm{E}-11 \\ 9.736 \mathrm{E}-09 & 4.218 \mathrm{E}-11 \\ 9.689 \mathrm{E}-09 & 4.195 \mathrm{E}-11 \\ 9.741 \mathrm{E}-09 & 4.220 \mathrm{E}-11 \\ 9.629 \mathrm{E}-09 & 4.167 \mathrm{E}-11 \\ 9.713 \mathrm{E}-09 & 4.207 \mathrm{E}-11 \\ 9.943 \mathrm{E}-09 & 4.317 \mathrm{E}-11 \\ 9.932 \mathrm{E}-09 & 4.312 \mathrm{E}-11 \\ 9.865 \mathrm{E}-09 & 4.280 \mathrm{E}-11 \\ 9.812 \mathrm{E}-09 & 4.254 \mathrm{E}-11 \\ 9.769 \mathrm{E}-09 & 4.234 \mathrm{E}-11 \\ 9.637 \mathrm{E}-09 & 4.170 \mathrm{E}-11 \\ 9.466 \mathrm{E}-09 & 4.088 \mathrm{E}-11 \\ 9.245 \mathrm{E}-09 & 3.983 \mathrm{E}-11 \\ 8.998 \mathrm{E}-09 & 3.865 \mathrm{E}-11 \\ 9 & \end{array}$




$\begin{array}{llll}16.05 & 25830 . & 1.486 \mathrm{E}-08 & 1.353 \mathrm{E}-08 \\ 16.15 & 25997 . & 1.473 \mathrm{E}-08 & 1.340 \mathrm{E}-08 \\ 16.12 & 25945 . & 1.477 \mathrm{E}-08 & 1.344 \mathrm{E}-08 \\ 16.12 & 25943 . & 1.477 \mathrm{E}-08 & 1.344 \mathrm{E}-08 \\ 16.15 . & 25987 . & 1.474 \mathrm{E}-08 & 1.341 \mathrm{E}-08 \\ 16.33 & 26278 . & 1.452 \mathrm{E}-08 & 1.320 \mathrm{E}-08 \\ 16.55 & 26634 . & 1.427 \mathrm{E}-08 & 1.295 \mathrm{E}-08 \\ 16.83 & 27085 . & 1.404 \mathrm{E}-08 & 1.284 \mathrm{E}-08 \\ 16.74 & 26943 . & 1.413 \mathrm{E}-08 & 1.293 \mathrm{E}-08 \\ 16.81 & 27047 . & 1.406 \mathrm{E}-08 & 1.286 \mathrm{E}-08 \\ 16.95 & 27286 . & 1.390 \mathrm{E}-08 & 1.270 \mathrm{E}-08 \\ 17.14 & 27592 . & 1.370 \mathrm{E}-08 & 1.251 \mathrm{E}-08 \\ 17.35 & 27928 . & 1.348 \mathrm{E}-08 & 1.230 \mathrm{E}-08 \\ 17.44 & 28071 . & 1.339 \mathrm{E}-08 & 1.221 \mathrm{E}-08 \\ 17.49 & 28153 . & 1.334 \mathrm{E}-08 & 1.216 \mathrm{E}-08 \\ 17.19 & 27666 . & 1.365 \mathrm{E}-08 & 1.246 \mathrm{E}-08 \\ 17.10 & 27513 . & 1.375 \mathrm{E}-08 & 1.256 \mathrm{E}-08 \\ 16.88 & 27167 . & 1.398 \mathrm{E}-08 & 1.278 \mathrm{E}-08 \\ 16.79 & 27025 . & 1.408 \mathrm{E}-08 & 1.288 \mathrm{E}-08 \\ 16.69 & 26859 . & 1.419 \mathrm{E}-08 & 1.299 \mathrm{E}-08 \\ 16.43 & 26439 . & 1.449 \mathrm{E}-08 & 1.328 \mathrm{E}-08 \\ 16.30 & 26227 . & 1.464 \mathrm{E}-08 & 1.343 \mathrm{E}-08 \\ 16.18 & 26040 . & 1.478 \mathrm{E}-08 & 1.356 \mathrm{E}-08 \\ 15.98 & 25719 . & 1.502 \mathrm{E}-08 & 1.380 \mathrm{E}-08 \\ 15.79 & 25410 . & 1.526 \mathrm{E}-08 & 1.403 \mathrm{E}-08 \\ 15.85 & 25506 . & 1.511 \mathrm{E}-08 & 1.377 \mathrm{E}-08 \\ 15.75 & 25345 . & 1.523 \mathrm{E}-08 & 1.389 \mathrm{E}-08 \\ 15.55 & 25027 . & 1.549 \mathrm{E}-08 & 1.414 \mathrm{E}-08 \\ 15.49 & 24934 . & 1.557 \mathrm{E}-08 & 1.422 \mathrm{E}-08 \\ 15.30 & 24618 . & 1.583 \mathrm{E}-08 & 1.448 \mathrm{E}-08 \\ 15.08 & 24272 . & 1.613 \mathrm{E}-08 & 1.477 \mathrm{E}-08 \\ 15.01 & 24153 . & 1.624 \mathrm{E}-08 & 1.487 \mathrm{E}-08 \\ 14.78 & 23794 . & 1.656 \mathrm{E}-08 & 1.519 \mathrm{E}-08 \\ 14.51 & 23347 . & 1.698 \mathrm{E}-08 & 1.560 \mathrm{E}-08 \\ 14.21 & 22863 . & 1.746 \mathrm{E}-08 & 1.606 \mathrm{E}-08 \\ 13.90 & 22376 . & 1.796 \mathrm{E}-08 & 1.656 \mathrm{E}-08 \\ 13.72 & 22083 . & 1.828 \mathrm{E}-08 & 1.687 \mathrm{E}-08 \\ 13.51 & 21739 . & 1.867 \mathrm{E}-08 & 1.724 \mathrm{E}-08 \\ 13.56 & 21817 . & 1.858 \mathrm{E}-08 & 1.716 \mathrm{E}-08 \\ 13.63 & 21937 . & 1.844 \mathrm{E}-08 & 1.703 \mathrm{E}-08 \\ 13.34 & 21469 . & 1.905 \mathrm{E}-08 & 1.774 \mathrm{E}-08 \\ 13.32 & 21429 . & 1.910 \mathrm{E}-08 & 1.779 \mathrm{E}-08\end{array}$

$8.868 \mathrm{E}-09$
$8.779 \mathrm{E}-09$
$8.806 \mathrm{E}-09$
$8.807 \mathrm{E}-09$
$8.784 \mathrm{E}-09$
$8.633 \mathrm{E}-09$
$8.453 \mathrm{E}-09$
$8.304 \mathrm{E}-09$
$8.372 \mathrm{E}-09$
$8.322 \mathrm{E}-09$
$8.209 \mathrm{E}-09$
$8.068 \mathrm{E}-09$
$7.918 \mathrm{E}-09$
$7.855 \mathrm{E}-09$
$7.819 \mathrm{E}-09$
$8.034 \mathrm{E}-09$
$8.104 \mathrm{E}-09$
$8.265 \mathrm{E}-09$
$8.332 \mathrm{E}-09$
$8.413 \mathrm{E}-09$
$8.621 \mathrm{E}-09$
$8.729 \mathrm{E}-09$
$8.826 \mathrm{E}-09$
$8.998 \mathrm{E}-09$
$9.168 \mathrm{E}-09$
$9.044 \mathrm{E}-09$
$9.134 \mathrm{E}-09$
$9.315 \mathrm{E}-09$
$9.369 \mathrm{E}-09$
$9.557 \mathrm{E}-09$
$9.769 \mathrm{E}-09$
$9.844 \mathrm{E}-09$
$1.008 \mathrm{E}-08$
$1.038 \mathrm{E}-08$
$1.072 \mathrm{E}-08$
$1.108 \mathrm{E}-08$
$1.131 \mathrm{E}-08$
$1.159 \mathrm{E}-08$
$1.153 \mathrm{E}-08$
$1.143 \mathrm{E}-08$
$1.189 \mathrm{E}-08$
$1.192 \mathrm{E}-08$

3. $803 E-11$

3. $761 \mathrm{E}-11$

3. $774 \mathrm{E}-11$

3. $774 \mathrm{E}-11$

3. $763 \mathrm{E}-11$

3. $691 \mathrm{E}-11$

3. $606 \mathrm{E}-11$

3. $699 \mathrm{E}-11$

3. $733 \mathrm{E}-11$

3. $708 \mathrm{E}-11$

3. $652 \mathrm{E}-11$

3. $582 \mathrm{E}-11$

3. $507 \mathrm{E}-11$

3. $476 \mathrm{E}-11$

3. $458 \mathrm{E}-11$

3. $565 \mathrm{E}-11$

3. $600 \mathrm{E}-11$

3. $680 \mathrm{E}-11$

3. $714 \mathrm{E}-11$

3. $754 \mathrm{E}-11$

3. $858 \mathrm{E}-11$

3. $912 \mathrm{E}-11$

3. $961 \mathrm{E}-11$

4. $047 \mathrm{E}-11$

4. $132 \mathrm{E}-11$

3. $887 \mathrm{E}-11$

3. $930 \mathrm{E}-11$

4. $016 \mathrm{E}-11$

4. 042E-11

4. $132 \mathrm{E}-11$

4. $234 \mathrm{E}-11$

4. $270 \mathrm{E}-11$

4. $381 \mathrm{E}-11$

4. $526 \mathrm{E}-11$

4. $691 \mathrm{E}-11$

4. $867 \mathrm{E}-11$

4. $977 \mathrm{E}-11$

5. $112 \mathrm{E}-11$

5. $081 \mathrm{E}-11$

$5.034 \mathrm{E}-11$

5. $516 \mathrm{E}-11$

5. $533 \mathrm{E}-11$ 


\begin{tabular}{|c|c|c|c|c|c|c|}
\hline ESE & 13.16 & 21171 . & 1. $941 E-08$ & 1. $810 \mathrm{E}-08$ & 1.215E-08 & $5.648 E-11$ \\
\hline ESE & 12.92 & 20798 . & 1. $989 \mathrm{E}-08$ & $1.856 \mathrm{E}-08$ & 1. $249 \mathrm{E}-08$ & $5.821 \mathrm{E}-11$ \\
\hline ESE & 12.90 & 20763 . & $1.993 \mathrm{E}-08$ & $1.861 \mathrm{E}-08$ & $1.253 E-08$ & $5.837 \mathrm{E}-11$ \\
\hline ESE & 12.65 & 20366 . & $2.046 E-08$ & $1.913 \mathrm{E}-08$ & $1.291 E-08$ & $6.031 \mathrm{E}-11$ \\
\hline ESE & 12.39 & 19933. & $2.106 E-08$ & $1.972 E-08$ & 1. $335 \mathrm{E}-08$ & $6.254 \mathrm{E}-11$ \\
\hline ESE & 12.43 & 20009. & $2.095 E-08$ & $1.961 E-08$ & 1. $327 E-08$ & $6.214 E-11$ \\
\hline ESE & 12.18 & 19607. & $2.154 \mathrm{E}-08$ & $2.018 E-08$ & 1. $370 \mathrm{E}-08$ & $6.430 \mathrm{E}-11$ \\
\hline ESE & 11.97 & 19261. & $2.206 \mathrm{E}-08$ & $2.070 E-08$ & $1.409 \mathrm{E}-08$ & $6.625 \mathrm{E}-11$ \\
\hline ESE & 11.76 & 18921. & $2.260 E-08$ & $2.123 E-08$ & 1. $448 \mathrm{E}-08$ & $6.826 \mathrm{E}-11$ \\
\hline ESE & 11.60 & 18667 . & $2.302 \mathrm{E}-08$ & $2.164 \mathrm{E}-08$ & $1.479 E-08$ & $6.982 \mathrm{E}-11$ \\
\hline $\mathrm{ESE}$ & 11.70 & 18836. & $2.274 E-08$ & $2.137 E-08$ & $1.458 E-08$ & $6.878 \mathrm{E}-11$ \\
\hline ESE & 11.43 & 18387. & $2.350 \Sigma-08$ & $2.211 E-08$ & 1. $514 \mathrm{E}-08$ & $7.161 \mathrm{E}-11$ \\
\hline ESE & 11.15 & 17941. & $2.429 E-08$ & $2.289 E-08$ & 1. $573 \mathrm{E}-08$ & $7.460 \mathrm{E}-11$ \\
\hline ESE & 10.87 & 17495. & $2.513 E-08$ & $2.372 E-08$ & $1.636 \mathrm{E}-08$ & $7.779 E-11$ \\
\hline ESE & 10.59 & 17051. & $2.603 E-08$ & $2.460 \mathrm{E}-08$ & $1.703 E-08$ & $8.118 \mathrm{E}-11$ \\
\hline ESE & 10.38 & 16709. & $2.675 \mathrm{E}-08$ & $2.531 E-08$ & $1.757 E-08$ & $8.395 \mathrm{E}-11$ \\
\hline ESE & 10.31 & 16588. & $2.702 E-08$ & $2.557 E-08$ & $1.777 \mathrm{E}-08$ & $8.496 \mathrm{E}-11$ \\
\hline ESE & 10.51 & 16913. & $2.631 \mathrm{E}-08$ & $2.488 E-08$ & 1. $725 \mathrm{E}-08$ & $8.228 E-11$ \\
\hline ESE & 10.60 & 17053. & $2.602 E-08$ & $2.459 \mathrm{E}-08$ & $1.703 E-08$ & $8.116 \mathrm{E}-11$ \\
\hline ESE & 10.51 & 16922 . & $2.630 E-08$ & $2.486 E-08$ & $1.723 E-08$ & 8. $221 E-11$ \\
\hline ESE & 10.30 & 16581. & $2.703 E-08$ & $2.559 E-08$ & $1.779 E-08$ & $8.502 E-11$ \\
\hline ESE & 10.25 & 16497. & $2.722 \mathrm{E}-08$ & $2.577 \mathrm{E}-08$ & $1.793 E-08$ & $8.574 \mathrm{E}-11$ \\
\hline ESE & 10.05 & 16176 . & $2.796 \mathrm{E}-08$ & $2.650 \mathrm{E}-08$ & 1. $848 \mathrm{E}-08$ & $8.856 \mathrm{E}-11$ \\
\hline ESE & 10.05 & 16176. & $2.796 \mathrm{E}-08$ & $2.650 E-08$ & 1. $848 \mathrm{E}-08$ & $8.856 E-11$ \\
\hline SE & 9.68 & 15581. & $2.757 \mathrm{E}-08$ & $2.615 \mathrm{E}-08$ & $1.835 \mathrm{E}-08$ & $7.006 \mathrm{E}-11$ \\
\hline SE & 9.40 & 15127 . & $2.866 \mathrm{E}-08$ & $2.723 E-08$ & $1.918 \mathrm{E}-08$ & $7.354 \mathrm{E}-11$ \\
\hline$S \dot{E}$ & 9.30 & 14972 . & $2.905 E-08$ & $2.761 E-08$ & $1.948 E-08$ & $.7 .478 E-11$ \\
\hline$S E$ & 9.46 & 15222 & $2.843 E-08$ & $2.699 E-08$ & 1. $900 \mathrm{E}-08$ & $7.279 E-11$ \\
\hline$S E$ & 9.44 & 15188. & $2.851 E-08$ & $2.708 E-08$ & $1.907 \mathrm{E}-08$ & $7.305 \mathrm{E}-11$ \\
\hline SE & 9.60 & 15443. & $2.789 E-08$ & $2.647 E-08$ & $1.859 E-08$ & $7.109 \mathrm{E}-11$ \\
\hline$S E$ & 9.80 & 15772 . & $2.713 E-08$ & $2.571 E-08$ & $1.801 \mathrm{E}-08$ & $6.867 \mathrm{E}-11$ \\
\hline SE & 10.01 & 16110. & $2.638 E-08$ & $2.498 E-08$ & $1.745 E-08$ & $6.632 \mathrm{E}-11$ \\
\hline$S E$ & 10.22 & 16455 . & $2.566 \mathrm{E}-08$ & $2.426 \mathrm{E}-08$ & $1.690 \mathrm{E}-08$ & $6.404 \mathrm{E}-11$ \\
\hline$S E$ & 10.29 & 16559. & $2.545 \mathrm{E}-08$ & $2.406 \mathrm{E}-08$ & $1.674 \mathrm{E}-08$ & $6.338 E-11$ \\
\hline$S E$ & 10.08 & 16229. & $2.613 E-08$ & $2.473 E-08$ & 1. $726 \mathrm{E}-08$ & $6.552 \mathrm{E}-11$ \\
\hline$S E$ & 9.90 & 15926. & $2.679 E-08$ & $2.538 \mathrm{E}-08$ & $1.775 E-08$ & $6.758 E-11$ \\
\hline$S E$ & 9.74 & 15677 . & $2.735 \mathrm{E}-08$ & $2.593 E-08$ & 1. $818 \mathrm{E}-08$ & $6.936 \mathrm{E}-11$ \\
\hline$S E$ & 9.59 & 15433. & $2.792 E-08$ & $2.649 E-08$ & $1.861 E-08$ & $7.116 \mathrm{E}-11$ \\
\hline$S E$ & 9.45 & 15201. & $2.848 E-08$ & $2.704 E-08$ & $1.904 \mathrm{E}-08$ & $7.295 \mathrm{E}-11$ \\
\hline$S E$ & 9.24 & 14870. & $2.931 E-08$ & $2.787 E-08$ & $1.968 \mathrm{E}-08$ & $7.562 \mathrm{E}-11$ \\
\hline SE & 8.96 & 14415 & $3.054 E-08$ & $2.908 E-08$ & $2.062 E-08$ & $7.955 \mathrm{E}-11$ \\
\hline$S E$ & 8.66 & 13936. & $3.193 E-08$ & $3.045 E-0.8$ & $2.169 E-08$ & $8.404 E-11$ \\
\hline
\end{tabular}




\begin{tabular}{|c|c|c|}
\hline$S E$ & 8.37 & 13466 \\
\hline$S E$ & 8.22 & 13227 . \\
\hline SSE & 7.86 & 12648 \\
\hline SSE & 7.60 & 12235 . \\
\hline SSE & 7.34 & 11806 \\
\hline SSE & 7.10 & 11421 \\
\hline SSE & 6.88 & 11067 \\
\hline SSE & 6.66 & 10725 \\
\hline SSE & 6.48 & 10432 \\
\hline SSE & 6.37 & 10244 \\
\hline SSE & 6.20 & 9978 \\
\hline SSE & 5.92 & 9534 \\
\hline SSE & 5.70 & 9167 \\
\hline SSE & 5.51 & 8875 \\
\hline SSE & 5.32 & 8555 \\
\hline$S$ & 5.02 & 8077 \\
\hline$S$ & 4.81 & 7736 \\
\hline$S$ & 4.60 & 7401 \\
\hline$S$ & 4.40 & 7078 \\
\hline S & 4.25 & 6843 \\
\hline$S$ & 4.04 & 6505 \\
\hline$S$ & 3.88 & 6251 \\
\hline$S$ & 3.78 & 6091 \\
\hline SSW & 3.56 & 5726 \\
\hline SSW & 3.39 & 5456 \\
\hline SSW & 3.28 & 5272 \\
\hline SSW & 3.01 & 4849 \\
\hline SSW & 2.93 & 4717 \\
\hline SW & 2.73 & 4388 \\
\hline SW & 2.58 & 4154 \\
\hline SW & 2.48 & 3992 \\
\hline$S W$ & 2.39 & 3841 \\
\hline SW & 2.38 & 3837 \\
\hline SW & 2.14 & 3452 \\
\hline SW & 2.09 & 3364 \\
\hline$S W$ & 1.85 & 2977 \\
\hline SW & 1.60 & 2580 \\
\hline WSW & 1.38 & 2224 \\
\hline WSW & 1.14 & 1838 \\
\hline WSW & 1.03 & 1659 \\
\hline W & 1.29 & 2072 \\
\hline WNW & 1.43 & 2309 \\
\hline
\end{tabular}

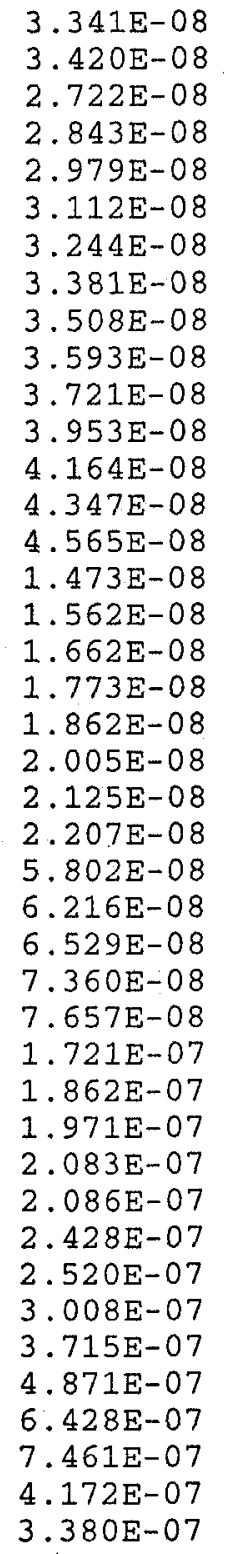

$2.284 \mathrm{E}-08$
$2.346 \mathrm{E}-08$
$1.881 \mathrm{E}-08$
$1.976 \mathrm{E}-08$
$2.083 \mathrm{E}-08$
$2.188 \mathrm{E}-08$
$2.292 \mathrm{E}-08$
$2.402 \mathrm{E}-08$
$2.503 \mathrm{E}-08$
$2.572 \mathrm{E}-08$
$2.663 \mathrm{E}-08$
$2.849 \mathrm{E}-08$
$3.020 \mathrm{E}-08$
$3.168 \mathrm{E}-08$
$3.345 \mathrm{E}-08$
$1.088 \mathrm{E}-08$
$1.161 \mathrm{E}-08$
$1.243 \mathrm{E}-08$
$1.334 \mathrm{E}-08$
$1.408 \mathrm{E}-08$
$1.526 \mathrm{E}-08$
$1.626 \mathrm{E}-08$
$1.694 \mathrm{E}-08$
$4.495 \mathrm{E}-08$
$4.845 \mathrm{E}-08$
$5.109 \mathrm{E}-08$
$5.818 \mathrm{E}-08$
$6.072 \mathrm{E}-08$
$1.377 \mathrm{E}-07$
$1.498 \mathrm{E}-07$
$1.593 \mathrm{E}-07$
$1.690 \mathrm{E}-07$
$1.693 \mathrm{E}-07$
$1.992 \mathrm{E}-07$
$2.072 \mathrm{E}-07$
$2.503 \mathrm{E}-07$
$3.132 \mathrm{E}-07$
$4.156 \mathrm{E}-07$
$5.566 \mathrm{E}-07$
$6.508 \mathrm{E}-07$
$3.580 \mathrm{E}-07$
$2.874 \mathrm{E}-07$

8. $883 E-11$

9. $143 \mathrm{E}-11$

7. $046 \mathrm{E}-11$

7. $431 \mathrm{E}-11$

7. $866 \mathrm{E}-11$

8. 291E-11

8. 714E-11

9.156E-11

9. $563 \mathrm{E}-11$

9. $839 \mathrm{E}-11$

1. $050 \mathrm{E}-10$

1. $140 \mathrm{E}-10$

1. $224 \mathrm{E}-10$

1. $298 \mathrm{E}-10$

1. $387 \mathrm{E}-10$

1. $324 \mathrm{E}-10$

1. $432 \mathrm{E}-10$

1. $550 \mathrm{E}-10$

1. $680 \mathrm{E}-10$

1. $785 \mathrm{E}-10$

1. $954 \mathrm{E}-10$

2. 099E-10

2. $198 \mathrm{E}-10$

3. $880 \mathrm{E}-10$

4. $229 \mathrm{E}-10$

4. 495E-10

5. $214 \mathrm{E}-10$

5. $475 \mathrm{E}-10$

9. $475 \mathrm{E}-10$

1. $044 \mathrm{E}-09$

1. $119 \mathrm{E}-09$

1. $198 \mathrm{E}-09$

1. $200 \mathrm{E}-09$

1. $445 \mathrm{E}-09$

1. $512 \mathrm{E}-09$

1. $871 \mathrm{E}-09$

2. $400 \mathrm{E}-09$

2. $605 \mathrm{E}-09$

3. $615 E-09$

4. 307E-09

2. $064 \mathrm{E}-09$

1. $522 \mathrm{E}-09$ 


\begin{tabular}{|c|c|c|}
\hline 1 & WNW & \\
\hline 1 & WNW & \\
\hline 1 & WINW & \\
\hline 1 & WNW & \\
\hline 1 & WNW & \\
\hline T AND BUILDING & PARAMETERS : & \\
\hline RELEASE HEIGHT & (METERS) & 0.00 \\
\hline DIAMETER & (METERS) & 0.00 \\
\hline EXIT VELOCITY & (METERS) & 0.00 \\
\hline
\end{tabular}

ALI GROUND LEVEL RELEASES.

$\begin{array}{llll}1.58 & 2544 . & 2.944 \mathrm{E}-07 & 2.918 \mathrm{E}-07 \\ 1.79 & 2881 . & 2.466 \mathrm{E}-07 & 2.441 \mathrm{E}-07 \\ 2.00 & 3225 . & 2.103 \mathrm{E}-07 & 2.080 \mathrm{E}-07 \\ 2.30 & 3694 . & 1.745 \mathrm{E}-07 & 1.723 \mathrm{E}-07 \\ 2.58 & 4155 . & 1.485 \mathrm{E}-07 & 1.463 \mathrm{E}-07\end{array}$

1. $485 \mathrm{E}-07$

\section{2. $483 \mathrm{E}-07$ $2.057 \mathrm{E}-07$ \\ 1. $736 \mathrm{E}-07$ \\ 1. $421 \mathrm{E}-07$}

$1.194 \mathrm{E}-07$
1. 287E-09

$1.037 \mathrm{E}-09$

8. 518E-10

$6.716 \mathrm{E}-10$

$5.460 \mathrm{E}-10$

CONSTANTS IN LABELED COMMON TRANFR

STABLE ELEMENT TRANSFER DATA

$\begin{array}{llcccccc}\text { ELEM } & \text { VEG/SOIL } & \text { MILK(D/L) } & \text { MEAT(D/KG) } & \text { ELEM } & \text { VEG/SOIL } & \text { MILK(D/L) } & \text { MEAT (D/KG) } \\ \text { H } & 4.8 E+00 & 1.0 E-02 & 1.2 E-02 & \text { SB } & 1.1 E-02 & 1.5 E-03 & 4.0 E-03 \\ \text { HE } & 5.0 E-02 & 2.0 E-02 & 2.0 E-02 & \text { TE } & 1.3 E+00 & 1.0 E-03 & 7.7 E-02 \\ \text { LI } & 8.3 E-04 & 5.0 E-02 & 1.0 E-02 & \text { I } & 2.0 E-02 & 6.0 E-03 & 2.9 E-03 \\ \text { BE } & 4.2 E-04 & 1.0 E-04 & 1.0 E-03 & \text { XE } & 1.0 E+01 & 2.0 E-02 & 2.0 E-02 \\ \text { B } & 1.2 E-01 & 2.7 E-03 & 8.0 E-04 & \text { CS } & 1.0 E-02 & 1.2 E-02 & 4.0 E-03 \\ \text { C } & 5.5 E+00 & 1.2 E-02 & 3.1 E-02 & \text { BA } & 5.0 E-03 & 4.0 E-04 & 3.2 E-03 \\ \text { N } & 7.5 E+00 & 2.2 E-02 & 7.7 E-02 & \text { LA } & 2.5 E-03 & 5.0 E-06 & 2.0 E-04 \\ \text { O } & 1.6 E+00 & 2.0 E-02 & 1.6 E-02 & \text { CE } & 2.5 E-03 & 6.0 E-04 & 1.2 E-03 \\ \text { F } & 6.5 E-04 & 1.4 E-02 & 1.5 E-01 & \text { PR } & 2.5 E-03 & 5.0 E-06 & 4.7 E-03 \\ \text { NE } & 1.4 E-01 & 2.0 E-02 & 2.0 E-02 & \text { ND } & 2.4 E-03 & 5.0 E-06 & 3.3 E-03 \\ \text { NA } & 5.2 E-02 & 4.0 E-02 & 3.0 E-02 & \text { PM } & 2.5 E-03 & 5.0 E-06 & 4.8 E-03 \\ \text { MG } & 1.3 E-01 & 1.0 E-02 & 5.0 E-03 & \text { SM } & 2.5 E-03 & 5.0 E-06 & 5.0 E-03 \\ \text { AL } & 1.8 E-04 & 5.0 E-04 & 1.5 E-03 & \text { EU } & 2.5 E-03 & 5.0 E-06 & 4.8 E-03 \\ \text { SI } & 1.5 E-04 & 1.0 E-04 & 4.0 E-05 & \text { GD } & 2.6 E-03 & 5.0 E-06 & 3.6 E-03 \\ \text { P } & 1.1 E+00 & 2.5 E-02 & 4.6 E-02 & \text { TB } & 2.6 E-03 & 5.0 E-06 & 4.4 E-03 \\ \text { S } & 5.9 E-01 & 1.8 E-02 & 1.0 E-01 & \text { DY } & 2.5 E-03 & 5.0 E-06 & 5.3 E-03 \\ \text { CL } & 5.0 E+00 & 5.0 E-02 & 8.0 E-02 & \text { HO } & 2.6 E-03 & 5.0 E-06 & 4.4 E-03 \\ \text { AR } & 6.0 E-01 & 2.0 E-02 & 2.0 E-02 & \text { ER } & 2.5 E-03 & 5.0 E-06 & 4.0 E-03 \\ \text { K } & 3.7 E-01 & 1.0 E-02 & 1.2 E-02 & \text { TM } & 2.6 E-03 & 5.0 E-06 & 4.4 E-03 \\ \text { CA } & 3.6 E-02 & 8.0 E-03 & 4.0 E-03 & \text { YB } & 2.5 E-03 & 5.0 E-06 & 4.0 E-03 \\ \text { SC } & 1.1 E-03 & 5.0 E-06 & 1.6 E-02 & \text { LU } & 2.6 E-03 & 5.0 E-06 & 4.4 E-03 \\ \text { TI } & 5.4 E-05 & 5.0 E-06 & 3.1 E-02 & \text { HF } & 1.7 E-04 & 5.0 E-06 & 4.0 E-01 \\ \text { V } & 1.3 E-03 & 1.0 E-03 & 2.3 E-03 & \text { TA } & 6.3 E-03 & 2.5 E-02 & 1.6 E+00 \\ \text { CR } & 2.5 E-04 & 2.2 E-03 & 2.4 E-03 & \text { W } & 1.8 E-02 & 5.0 E-04 & 1.3 E-03 \\ \text { MN } & 2.9 E-02 & 2.5 E-04 & 8.0 E-04 & \text { RE } & 2.5 E-01 & 2.5 E-02 & 8.0 E-03 \\ \text { FE } & 6.6 E-04 & 1.2 E-03 & 4.0 E-02 & \text { OS } & 5.0 E-02 & 5.0 E-03 & 4.0 E-01\end{array}$

ILDING HEIGHT

MTN CRS SEC . AREA

(METERS)

(METERS)

10.0

HEAT EMISSION RATE

(SQ.METERS)

100.0

0.0

100.0 


$\begin{array}{llllllll}\mathrm{CO} & 9.4 \mathrm{E}-03 & 1.0 \mathrm{E}-03 & 1.3 \mathrm{E}-02 & \mathrm{IR} & 1.3 \mathrm{E}+01 & 5.0 \mathrm{E}-03 & 1.5 \mathrm{E}-03 \\ \mathrm{NI} & 1.9 \mathrm{E}-02 & 6.7 \mathrm{E}-03 & 5.3 \mathrm{E}-03 & \mathrm{PT} & 5.0 \mathrm{E}-01 & 5.0 \mathrm{E}-03 & 4.0 \mathrm{E}-03 \\ \mathrm{CU} & 1.2 \mathrm{E}-01 & 1.4 \mathrm{E}-02 & 8.0 \mathrm{E}-03 & \mathrm{AU} & 2.5 \mathrm{E}-03 & 5.0 \mathrm{E}-03 & 8.0 \mathrm{E}-03 \\ \mathrm{ZN} & 4.0 \mathrm{E}-01 & 3.9 \mathrm{E}-02 & 3.0 \mathrm{E}-02 & \mathrm{HG} & 3.8 \mathrm{E}-01 & 3.8 \mathrm{E}-02 & 2.6 \mathrm{E}-01 \\ \mathrm{GA} & 2.5 \mathrm{E}-04 & 5.0 \mathrm{E}-05 & 1.3 \mathrm{E}+00 & \mathrm{TL} & 2.5 \mathrm{E}-01 & 2.2 \mathrm{E}-02 & 4.0 \mathrm{E}-02 \\ \mathrm{GE} & 1.0 \mathrm{E}-01 & 5.0 \mathrm{E}-04 & 2.0 \mathrm{E}+01 & \mathrm{~PB} & 6.8 \mathrm{E}-02 & 6.2 \mathrm{E}-04 & 2.9 \mathrm{E}-04 \\ \mathrm{AS} & 1.0 \mathrm{E}-02 & 6.0 \mathrm{E}-03 & 2.0 \mathrm{E}-03 & \mathrm{BI} & 1.5 \mathrm{E}-01 & 5.0 \mathrm{E}-04 & 1.3 \mathrm{E}-02 \\ \mathrm{SE} & 1.3 \mathrm{E}+00 & 4.5 \mathrm{E}-02 & 1.5 \mathrm{E}-02 & \mathrm{PO} & 1.5 \mathrm{E}-01 & 3.0 \mathrm{E}-04 & 1.2 \mathrm{E}-02 \\ \mathrm{BR} & 7.6 \mathrm{E}-01 & 5.0 \mathrm{E}-02 & 2.6 \mathrm{E}-02 & \mathrm{AT} & 2.5 \mathrm{E}-01 & 5.0 \mathrm{E}-02 & 8.0 \mathrm{E}+00 \\ \mathrm{KR} & 3.0 \mathrm{E}+00 & 2.0 \mathrm{E}-02 & 2.0 \mathrm{E}-02 & \mathrm{RN} & 3.5 \mathrm{E}+00 & 2.0 \mathrm{E}-02 & 2.0 \mathrm{E}-02 \\ \mathrm{RB} & 1.3 \mathrm{E}-01 & 3.0 \mathrm{E}-02 & 3.1 \mathrm{E}-02 & \mathrm{FR} & 1.0 \mathrm{E}-02 & 5.0 \mathrm{E}-02 & 2.0 \mathrm{E}-02 \\ \mathrm{SR} & 1.7 \mathrm{E}-02 & 8.0 \mathrm{E}-04 & 6.0 \mathrm{E}-04 & \mathrm{RA} & 3.1 \mathrm{E}-04 & 8.0 \mathrm{E}-03 & 3.4 \mathrm{E}-02 \\ \mathrm{Y} & 2.6 \mathrm{E}-03 & 1.0 \mathrm{E}-05 & 4.6 \mathrm{E}-03 & \mathrm{AC} & 2.5 \mathrm{E}-03 & 5.0 \mathrm{E}-06 & 6.0 \mathrm{E}-02 \\ \mathrm{ZR} & 1.7 \mathrm{E}-04 & 5.0 \mathrm{E}-06 & 3.4 \mathrm{E}-02 & \mathrm{TH} & 4.2 \mathrm{E}-03 & 5.0 \mathrm{E}-06 & 2.0 \mathrm{E}-04 \\ \mathrm{NB} & 9.4 \mathrm{E}-03 & 2.5 \mathrm{E}-03 & 2.8 \mathrm{E}-01 & \mathrm{PA} & 2.5 \mathrm{E}-03 & 5.0 \mathrm{E}-06 & 8.0 \mathrm{E}+02 \\ \mathrm{MO} & 1.2 \mathrm{E}-01 & 7.5 \mathrm{E}-03 & 8.0 \mathrm{E}-03 & \mathrm{U} & 2.5 \mathrm{E}-03 & 5.0 \mathrm{E}-04 & 3.4 \mathrm{E}-04 \\ \mathrm{TC} & 2.5 \mathrm{E}-01 & 2.5 \mathrm{E}-02 & 4.0 \mathrm{E}-01 & \mathrm{NP} & 2.5 \mathrm{E}-03 & 5.0 \mathrm{E}-06 & 2.0 \mathrm{E}-04 \\ \mathrm{RU} & 5.0 \mathrm{E}-02 & 1.0 \mathrm{E}-06 & 4.0 \mathrm{E}-01 & \mathrm{PU} & 2.5 \mathrm{E}-04 & 2.0 \mathrm{E}-06 & 1.4 \mathrm{E}-05 \\ \mathrm{RH} & 1.3 \mathrm{E}+01 & 1.0 \mathrm{E}-02 & 1.5 \mathrm{E}-03 & \mathrm{AM} & 2.5 \mathrm{E}-04 & 5.0 \mathrm{E}-06 & 2.0 \mathrm{E}-04 \\ \mathrm{PD} & 5.0 \mathrm{E}+00 & 1.0 \mathrm{E}-02 & 4.0 \mathrm{E}-03 & \mathrm{CM} & 2.5 \mathrm{E}-03 & 5.0 \mathrm{E}-06 & 2.0 \mathrm{E}-04 \\ \mathrm{AG} & 1.5 \mathrm{E}-01 & 5.0 \mathrm{E}-02 & 1.7 \mathrm{E}-02 & \mathrm{BK} & 2.5 \mathrm{E}-03 & 5.0 \mathrm{E}-06 & 2.0 \mathrm{E}-04 \\ \mathrm{CD} & 3.0 \mathrm{E}-01 & 1.2 \mathrm{E}-04 & 5.3 \mathrm{E}-04 & \mathrm{CF} & 2.5 \mathrm{E}-03 & 5.0 \mathrm{E}-06 & 2.0 \mathrm{E}-04 \\ \mathrm{IN} & 2.5 \mathrm{E}-01 & 1.0 \mathrm{E}-04 & 8.0 \mathrm{E}-03 & \mathrm{ES} & 2.5 \mathrm{E}-03 & 5.0 \mathrm{E}-06 & 2.0 \mathrm{E}-04 \\ \mathrm{SN} & 2.5 \mathrm{E}-03 & 2.5 \mathrm{E}-03 & 8.0 \mathrm{E}-02 & \mathrm{FM} & 2.5 \mathrm{E}-03 & 5.0 \mathrm{E}-06 & 2.0 \mathrm{E}-04 \\ & & & & & & \end{array}$

GOAT MILK TRANSFER PARAMETERS

\begin{tabular}{rllllllllllllll} 
ELEMENT & H & \multicolumn{1}{c}{ B } & C & MG & P & CL & K & CA & FE & CU & SR & I & CS & PO \\
PARAMETER & .17000 & .01200 & .10000 & .04200 & .25000 & .50000 & .05700 & .47000 & .00130 & .01300 & .01400 & .06000 & .30000 &
\end{tabular}
.00180

TRANSPORT TIMES (SEC) TIM= $5.18 \mathrm{E}+05 \quad 2.59 \mathrm{E}+05 \quad 1.21 \mathrm{E}+06 \quad 5.18 \mathrm{E}+06 \quad 1.73 \mathrm{E}+05 \quad 8.64 \mathrm{E}+042.59 \mathrm{E}+06 \quad 7.78 \mathrm{E}+06$ 0 01

PHYSICAL CONSTANTS

0 AREA OF ANULAR SECTIONS AT GIVEN MILES

$\begin{array}{llll}2 & 3 & 4 & 5\end{array}$

$5 \quad 10$

20

30

40

50 


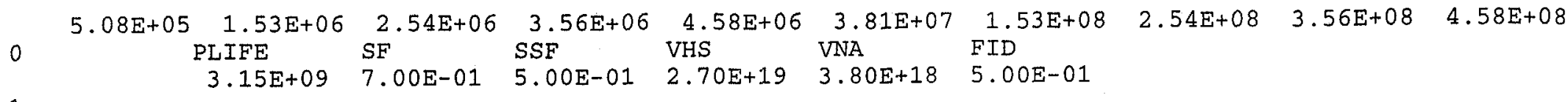

USAGE CONSTANTS

0

OVARIABLE

OAVINH

OAVLVEG

OAVMET

OAVMLK

OAVVEG

OPOPF

0

FOR INDIVIDUAL DOSE

0 VARIABLE

INFANTS

OSLVEG

$0.00 \mathrm{E}+00$

1. $40 \mathrm{E}+03$

OSPINH

$0.00 \mathrm{E}+00$

OSPMET

$2.44 \mathrm{E}+02$

$0.00 \mathrm{E}+00$

INFANTS + CHILDREN

3. $70 \mathrm{E}+03$

8. $50 \mathrm{E}+00$

1. $70 \mathrm{E}+01$

1. $86 E+02$

1. $71 \mathrm{E}+02$

$0.00 E+00$

OSPVEG

\section{CHILDREN}

1. $70 E+01$

3. $70 \mathrm{E}+03$

3. $00 E+01$

2. $44 \mathrm{E}+02$

$2.76 \mathrm{E}+02$

TEENAGERS

8. $00 \mathrm{E}+03$

1. $40 \mathrm{E}+01$

2. $70 \mathrm{E}+01$

$2.18 \mathrm{E}+02$

2. $05 \mathrm{E}+02$

TEENAGERS

2. $80 \mathrm{E}+01$

$8.00 E+03$

4. $80 \mathrm{E}+01$

2. $97 \mathrm{E}+02$

3. $34 E+02$

$3.00 \mathrm{E}+08$
ADULTS

8. $00 \mathrm{E}+03$

2. $10 \mathrm{E}+01$

4. $30 \mathrm{E}+01$

1. $20 \mathrm{E}+02$

1. $63 \mathrm{E}+02$

1. $00 \mathrm{E}+00$

ADULTS

4. $30 \mathrm{E}+01$

8. $00 \mathrm{E}+03$

8. $10 \mathrm{E}+01$

2. $30 \mathrm{E}+02$

2. $76 \mathrm{E}+02$

$<$ MAXIGASP TEST CASE NUMBER 1

(DOSES/CURIE/UNIT X/Q \& D/Q TO TDS)

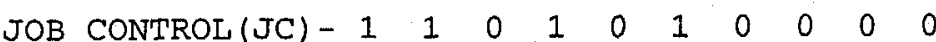

ERACTIONS OF

LEAFY VEGETABLES FROM GARDEN(FV)-1.00 YEAR MILK COWS/BEEF ANIMALS/GOATS ON PASTURE(FP/FB/FGT) -

$1.00 / 1.00 / 0.79$

OTHER EDIBLES FROM GARDEN(FG)-0.76 MILK COW/BEEF/GOAT DAILY INTAKE FROM PASTURE(FPF/FBF/FPG) -

$0.56 / 0.75 / 0.85$

HUMIDITY $(G / M * * 3)-11.40$

UNTT RELEASES FOR SPECIAI GASPAR-CODE RUN

$\mathrm{UML}=1.00 \mathrm{E}+00 \mathrm{JC1}=0 . \mathrm{JC2}=0$

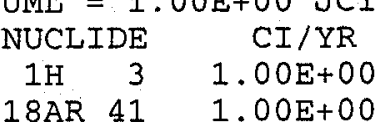

$53133 \quad 1.00 \mathrm{E}+00$ 


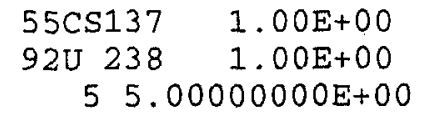

1 MAXIMUM AND AVERAGE RADIONUCLIDE AIR CONCENTRATIONS ON SRS BZ BOUNDARY, PICOCURIES PER CUBIC METER: ONUCLIDE MAXIMUM AVERAGE NUCLIDE MAXIMUM AVERAGE NUCLIDE MAXIMUM AVERAGE NUCLIDE MAXIMUM AVERAGE

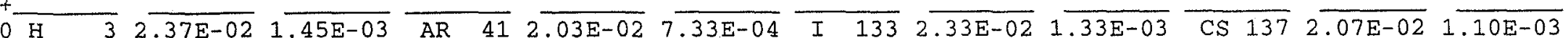
0 U $2382.07 \mathrm{E}-02 \quad 1.10 \mathrm{E}-03$

1LOCATION OF MAXIMUM ADULT WITH RESPECT TO RELEASE POINTS --

OPOINT DIRECTION MILES $X / Q \quad X / Q|D E C \quad X / Q| D E P \quad$ DEPOSIT

-

1

1 WSW $\quad 1.03 \quad 7.461 \mathrm{E}-07 \quad 7.423 \mathrm{E}-07 \quad 6.508 \mathrm{E}-07 \quad 4.307 \mathrm{E}-09$

$<$ MAXIGASP TEST CASE NUMBER 1

SPECIAL LOCATION \# 1 MAX INDIVIDUAL AT 1.03 MILES WSW

\begin{tabular}{|c|c|c|c|c|c|c|c|c|}
\hline PATHWAY & EFF.D.E. & GI-LLI & B. MAR. & LIVER & B.SURF. & THYROID & LUNG & SKIN \\
\hline PLUME & $9.44 \mathrm{E}-05$ & $9.44 \mathrm{E}-05$ & $9.44 E-05$ & $9.44 \mathrm{E}-05$ & -05 & -05 & $E-05$ & $2.14 \mathrm{E}-$ \\
\hline ROUND & $6.83 E+00$ & $6.83 E+00$ & $6.83 \mathrm{E}+00$ & $6.83 E+00$ & $6.83 E+00$ & $E+00$ & $6.83 E+00$ & $2.47 E+C$ \\
\hline VEGET & $5.02 \mathrm{E}+00$ & $9.56 \mathrm{E}-01$ & $5.34 E+00$ & 1. $25 E-05$ & $6.68 \mathrm{E}+01$ & $8.83 E-01$ & $8.83 E-01$ & $1.25 E-05$ \\
\hline MEAT & $3.78 E-02$ & $2.87 E-02$ & $3.75 E-02$ & $2.12 E-06$ & $1.90 \mathrm{E}-01$ & $2.65 \mathrm{E}-02$ & $2.65 \mathrm{E}-02$ & $2.12 \mathrm{E}-06$ \\
\hline Low. & 3.4 & 01 & 3 & 5.0 & +00 & 2.7 & 01 & 6 \\
\hline NHAI & $1.98 \mathrm{E}+01$ & $5.64 E-03$ & $5.14 \mathrm{E}-03$ & $1.80 \mathrm{E}-05$ & $4.81 E-03$ & $3.84 E-02$ & $1.65 E+02$ & $1.80 \mathrm{E}-05$ \\
\hline
\end{tabular}


1

<MAXIGASP TEST CASE NUMBER 1

ANNUAL INDIVIDUAL DOSE (MREM) SUMMARY BY PATHWAY \& NUCLIDE

SPECIAL LOCATION \# 1 MAX INDIVIDUAL

PATHWAY $=$ PLUME

\begin{tabular}{|c|c|c|c|c|c|c|c|c|}
\hline NUCLIDE & $E F F, D . E$. & GI-LLI & B. MAR. & LIVER & B. SURF. & THYROID & LUNG & SKIN \\
\hline AR 41 & $\begin{array}{r}9.44 \mathrm{E}-05 \\
100.008\end{array}$ & $\begin{array}{r}9.44 \mathrm{E}-05 \\
100.008\end{array}$ & $\begin{array}{r}9.44 \mathrm{E}-05 \\
100.00 \%\end{array}$ & $\begin{array}{r}9.44 \mathrm{E}-05 \\
100.00 \%\end{array}$ & $\begin{array}{r}9.44 \mathrm{E}-05 \\
100.00 \%\end{array}$ & $\begin{array}{r}9.44 \mathrm{E}-05 \\
100.00 \%\end{array}$ & $\begin{array}{r}9.44 E-05 \\
100.00 \%\end{array}$ & $\begin{array}{r}2.14 \mathrm{E}-04 \\
100.00 \%\end{array}$ \\
\hline *TOTAL * & $9.44 E-05$ & $9.44 \mathrm{E}-0.5$ & $9.44 \mathrm{E}-05$ & $9.44 E-05$ & $9.44 E-05$ & $9.44 \mathrm{E}-05$ & $9.44 E-05$ & $2.14 E-04$ \\
\hline
\end{tabular}

1

<MAXIGASP TEST CASE NUMBER 1

ANNUAL INDIVIDUAL DOSE (MREM) SUMMARY BY PATHWAY \& NUCLIDE SPECIAL LOCATION \# 1 MAX INDIVIDUAL

PATHWAY = GROUND

NUCLIDE
EFF.D.E.

1

<MAXIGASP TEST CASE NUMBER 1

ANNUAL INDIVIDUAL DOSE (MREM) SUMMARY BY PATHWAY \& NUCLIDE

SPECIAL LOCATION \# 1 MAX INDIVIDUAL

PATHWAY = VEGET

AGE GROUP = ADULT

NUCLIDE EFF.D.E.

GI-LLI

B.MAR .

LIVER

B. SURF .

THYROID

LUNG

SKIN

-




\begin{tabular}{|c|c|c|c|c|c|c|c|c|}
\hline $\mathrm{H}$ & $\begin{array}{r}1.25 E-05 \\
0.00 \%\end{array}$ & $\begin{array}{r}1.25 E-05 \\
0.008\end{array}$ & $\begin{array}{r}1.25 E-05 \\
0.00 \%\end{array}$ & $\begin{array}{r}1.25 E-05 \\
100.00 \%\end{array}$ & $\begin{array}{r}1.25 \mathrm{E}-05 \\
0.00 \%\end{array}$ & $\begin{array}{r}1.25 \mathrm{E}-05 \\
0.00 \%\end{array}$ & $\begin{array}{r}1.25 \mathrm{E}-05 \\
0.00 \%\end{array}$ & $\begin{array}{r}1.25 E-05 \\
100.00 \%\end{array}$ \\
\hline $\operatorname{Cs} 137$ & $\begin{array}{r}9.20 \mathrm{E}-01 \\
18.32 \%\end{array}$ & $\begin{array}{r}9.56 \mathrm{E}-01 \\
100.008\end{array}$ & $\begin{array}{r}8.83 E-01 \\
16.538\end{array}$ & $\begin{array}{r}0.00 \mathrm{E}+00 \\
0.008\end{array}$ & $\begin{array}{r}8.83 E-01 \\
1.32 \%\end{array}$ & $\begin{array}{r}8.83 \mathrm{E}-01 \\
100.00 \%\end{array}$ & $\begin{array}{r}8.83 \mathrm{E}-01 \\
100.00 \%\end{array}$ & $\begin{array}{r}0.00 \mathrm{E}+00 \\
0.00 \%\end{array}$ \\
\hline U 238 & $\begin{array}{r}4.10 \mathrm{E}+00 \\
81.68 \%\end{array}$ & $\begin{array}{r}0.00 E+00 \\
0.00 \%\end{array}$ & $\begin{array}{r}4.46 \mathrm{E}+00 \\
83.47 \%\end{array}$ & $\begin{array}{r}0.00 \mathrm{E}+00 \\
0.00 \%\end{array}$ & $\begin{array}{r}6.60 E+01 \\
98.68 \%\end{array}$ & $\begin{array}{r}0.00 E+00 \\
0.00 \%\end{array}$ & $\begin{array}{r}0.00 E+00 \\
0.00 \%\end{array}$ & $\begin{array}{r}0.00 E+00 \\
0.00 \%\end{array}$ \\
\hline *TOTAL * & $5.02 \mathrm{E}+00$ & $9.56 \mathrm{E}-01$ & $5.34 E+00$ & $1.25 \mathrm{E}-05$ & $6.68 \mathrm{E}+01$ & $8.83 E-01$ & $8.83 E-01$ & $1.25 \mathrm{E}-05$ \\
\hline
\end{tabular}

<MAXIGASP TEST CASE NUMBER 1

ANNUAL INDIVIDUAL DOSE (MREM) SUMMARY BY PATHWAY \& NUCLIDE

SPECIAL LOCATION \# 1 MAX INDIVIDUAL

PATHWAY $=$ MEAT

AGE GROUP $=$ ADULT
NUCLIDE
EFF.D.E.

1

<MAXIGASP TEST CASE NUMBER 1

ANNUAL INDIVIDUAL DOSE (MREM) SUMMARY BY PATHWAY \& NUCLIDE

SPECIAL LOCATION \# 1 MAX INDIVIDUAL

PATHWAY $=$ COW MILK

$\begin{array}{lll}\text { AGE GROUP }=\text { ADULT } & & \\ \text { NUCLIDE EFF.D.E. GI-LLI } & \text { B.MAR. GIVER } & \text { B.SURF. THYROID LUNG }\end{array}$ 


\begin{tabular}{|c|c|c|c|c|c|c|c|c|}
\hline $\mathrm{H}$ & $\begin{array}{r}5.01 \mathrm{E}-06 \\
0.008\end{array}$ & $\begin{array}{r}5.01 \mathrm{E}-06 \\
0.008\end{array}$ & $\begin{array}{r}5.01 E-06 \\
0.008\end{array}$ & $\begin{array}{r}5.01 E-06 \\
100.008\end{array}$ & $\begin{array}{r}5.01 \mathrm{E}-06 \\
0.00 \%\end{array}$ & $\begin{array}{r}5.01 \mathrm{E}-06 \\
0.008\end{array}$ & $\begin{array}{r}5.01 \mathrm{E}-06 \\
0.00 \%\end{array}$ & $\begin{array}{r}5.01 \mathrm{E}-06 \\
100.008\end{array}$ \\
\hline $\operatorname{cs} 137$ & $\begin{array}{r}2.87 \mathrm{E}-01 \\
84.578\end{array}$ & $\begin{array}{r}2.99 \mathrm{E}-01 \\
100.008\end{array}$ & $\begin{array}{r}2.76 \mathrm{E}-01 \\
82.88 \%\end{array}$ & $\begin{array}{r}0.00 E+00 \\
0.00 \%\end{array}$ & $\begin{array}{r}2.76 \mathrm{E}-01 \\
24.65 \%\end{array}$ & $\begin{array}{r}2.76 \mathrm{E}-01 \\
100.008\end{array}$ & $\begin{array}{r}2.76 \mathrm{E}-01 \\
100.008\end{array}$ & $\begin{array}{r}0.00 E+00 \\
0.00 \%\end{array}$ \\
\hline U 238 & $\begin{array}{r}5.24 \mathrm{E}-02 \\
15.428\end{array}$ & $\begin{array}{r}0.00 \mathrm{E}+00 \\
0.00 \%\end{array}$ & $\begin{array}{r}5.70 \mathrm{E}-02 \\
17.118\end{array}$ & $\begin{array}{r}0.00 \mathrm{E}+00 \\
0.00 \%\end{array}$ & $\begin{array}{r}8.43 \mathrm{E}-01 \\
75.348\end{array}$ & $\begin{array}{r}0.00 E+00 \\
0.00 \%\end{array}$ & $\begin{array}{r}0.00 E+00 \\
0.00 \%\end{array}$ & $\begin{array}{r}0.00 E+00 \\
0.008\end{array}$ \\
\hline *TOTAL * & $3.40 \mathrm{E}-01$ & $2.99 E-01$ & $3.33 E-01$ & $5.01 E-06$ & $1.12 \mathrm{E}+00$ & $2.76 \mathrm{E}-01$ & $2.76 \mathrm{E}-01$ & $5.01 E-06$ \\
\hline
\end{tabular}

1

<MAXIGASP TEST CASE NUMBER 1

ANNUAL INDIVIDUAL DOSE (MREM) SUMMARY BY PATHWAY \& NUCLIDE

SPECIAL LOCATION \# 1 MAX INDIVIDUAL

PATHWAY = INHAI

AGE GROUP $=$ ADULT
NUCLIDE
EFF.D.E.

1

$<$ MAXIGASP TEST CASE NUMBER 1

ANNUAL INDIVIDUAL DOSE (MREM) SUMMARY BY PATHWAY \& NUCLIDE

SPECIAL LOCATION \# 1 MAX INDIVIDUAL

PATHWAY $=$ TOTAL $/ \mathrm{CM}$ 


\begin{tabular}{|c|c|c|c|c|c|c|c|c|}
\hline $\begin{array}{l}\text { AGE GROUE } \\
\text { NUCLIDE }\end{array}$ & $\begin{array}{l}=\text { ADULT } \\
\text { EFF.D.E. }\end{array}$ & $G I-L L I$ & B. MAR. & LIVER & B. SURF. & THYROID & LUNG & SKIN \\
\hline 3 & $\begin{array}{r}3.76 \mathrm{E}-05 \\
0.00 \%\end{array}$ & $\begin{array}{r}3.76 \mathrm{E}-05 \\
0.00 \%\end{array}$ & $\begin{array}{r}3.76 \mathrm{E}-05 \\
0.008\end{array}$ & $\begin{array}{r}3.76 \mathrm{E}-05 \\
0.00 \%\end{array}$ & $\begin{array}{r}3.76 \mathrm{E}-05 \\
0.008\end{array}$ & $\begin{array}{r}3.76 \mathrm{E}-05 \\
0.00 \%\end{array}$ & $\begin{array}{r}3.76 \mathrm{E}-05 \\
0.00 \%\end{array}$ & $\begin{array}{r}3.76 \mathrm{E}-05 \\
0.00 \%\end{array}$ \\
\hline AR 41 & $\begin{array}{r}9.44 E-05 \\
0.008\end{array}$ & $\begin{array}{r}9.44 \mathrm{E}-05 \\
0.00 \%\end{array}$ & $\begin{array}{r}9.44 \mathrm{E}-05 \\
0.00 \%\end{array}$ & $\begin{array}{r}9.44 \mathrm{E}-05 \\
0.008\end{array}$ & $\begin{array}{r}9.44 \mathrm{E}-05 \\
0.00 \%\end{array}$ & $\begin{array}{r}9.44 E-05 \\
0.008\end{array}$ & $\begin{array}{r}9.44 E-05 \\
0.00 \%\end{array}$ & $\begin{array}{r}2.14 E-04 \\
0.008\end{array}$ \\
\hline I 133 & $\begin{array}{r}1.01 \mathrm{E}-03 \\
0.008\end{array}$ & $\begin{array}{r}0.00 \mathrm{E}+00 \\
0.00 \%\end{array}$ & $\begin{array}{r}0.00 E+00 \\
0.00 \%\end{array}$ & $\begin{array}{r}0.00 E+00 \\
0.00 \%\end{array}$ & $\begin{array}{r}0.00 \mathrm{E}+00 \\
0.008\end{array}$ & $\begin{array}{r}3.36 \mathrm{E}-02 \\
0.42 \%\end{array}$ & $\begin{array}{r}0.00 E+00 \\
0.008\end{array}$ & $\begin{array}{r}0.00 E+00 \\
0.00 \%\end{array}$ \\
\hline $\operatorname{cs} 137$ & $\begin{array}{r}8.05 E+00 \\
25.118\end{array}$ & $\begin{array}{r}8.10 E+00 \\
99.768\end{array}$ & $\begin{array}{r}8.00 E+00 \\
63.79 \%\end{array}$ & $\begin{array}{r}6.81 E+00 \\
99.71 \%\end{array}$ & $\begin{array}{r}8.00 E+00 \\
10.67 \%\end{array}$ & $\begin{array}{r}8.00 E+00 \\
99.348\end{array}$ & $\begin{array}{r}8.01 \mathrm{E}+00 \\
4.62 \%\end{array}$ & $\begin{array}{r}2.46 \mathrm{E}+01 \\
99.358\end{array}$ \\
\hline U 238 & $\begin{array}{r}2.40 E+01 \\
74.88 \%\end{array}$ & $\begin{array}{r}1.95 \mathrm{E}-02 \\
0.248\end{array}$ & $\begin{array}{r}4.54 \mathrm{E}+00 \\
36.21 \%\end{array}$ & $\begin{array}{r}1.95 E-02 \\
0.298\end{array}$ & $\begin{array}{r}6.70 \mathrm{E}+01 \\
89.33 \%\end{array}$ & $\begin{array}{r}1.95 \mathrm{E}-02 \\
0.24 \%\end{array}$ & $\begin{array}{r}1.65 E+02 \\
95.388\end{array}$ & $\begin{array}{r}1.60 \mathrm{E}-01 \\
0.658\end{array}$ \\
\hline *TOTAL * & $3.21 E+01$ & $8.12 E+00$ & $1.25 E+01$ & $6.83 \mathrm{E}+00$ & $7.50 \mathrm{E}+01$ & $8.06 E+00$ & 1. $73 E+02$ & $2.47 E+01$ \\
\hline \multicolumn{9}{|c|}{ LSECTOR-SPECIFIC ADULT MAXIMUM INDIVIDUAL DOSE (MREM) } \\
\hline DIRECTION & MILES & $X / Q$ & $X / Q \mid D E C$ & $X / Q \mid D E P$ & DEPOSIT & DOSE & & \\
\hline$n$ & 9.34 & $2.185 \mathrm{E}-08$ & $2.080 \mathrm{E}-08$ & $1.465 \mathrm{E}-08$ & $7.052 \mathrm{E}-11$ & $6.55 \mathrm{E}-01$ & & \\
\hline NNE & 12.92 & $1.709 \mathrm{E}-08$ & $1.591 \mathrm{E}-08$ & $1.073 E-08$ & $4.564 \mathrm{E}-11$ & $4.65 \mathrm{E}-01$ & & \\
\hline $\mathrm{NE}$ & 16.37 & $1.207 E-08$ & $1.102 \mathrm{E}-08$ & $7.179 E-09$ & $3.161 \mathrm{E}-11$ & $3.16 E-01$ & & \\
\hline ENE & 14.14 & $1.551 \mathrm{E}-08$ & $1.434 \mathrm{E}-08$ & $9.545 \mathrm{E}-09$ & $4.322 E-11$ & $4.22 E-01$ & & \\
\hline$E$ & 13.51 & $1.867 \mathrm{E}-08$ & $1.724 \mathrm{E}-08$ & 1. $159 \mathrm{E}-08$ & $5.112 \mathrm{E}-11$ & $5.09 E-01$ & & \\
\hline ESE & 10.05 & $2.796 \mathrm{E}-08$ & $2.650 \mathrm{E}-08$ & $1.848 \mathrm{E}-08$ & $8.856 \mathrm{E}-11$ & $8.26 E-01$ & & \\
\hline $\mathrm{SE}$ & 8.22 & $3.420 \mathrm{E}-08$ & $3.270 E-08$ & $2.346 \mathrm{E}-08$ & $9.143 \mathrm{E}-11$ & $9.86 \mathrm{E}-01$ & & \\
\hline SSE & 5.32 & $4.565 E-08$ & $4.429 E-08$ & $3.345 \mathrm{E}-08$ & 1. $387 \mathrm{E}-10$ & $1.42 \mathrm{E}+00$ & & \\
\hline S & 3.78 & $2.207 \mathrm{E}-08$ & $2.155 \mathrm{E}-08$ & 1. $694 \mathrm{E}-08$ & $2.198 \mathrm{E}-10$ & 1. $15 \mathrm{E}+00$ & & \\
\hline SSW & 2.93 & $7.657 E-08$ & $7.542 \mathrm{E}-08$ & $6.072 \mathrm{E}-08$ & $5.475 \mathrm{E}-10$ & $3.42 \mathrm{E}+00$ & 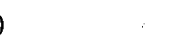 & \\
\hline SW & 1.60 & $3.715 E-07$ & $3.690 \mathrm{E}-07$ & $3.132 \mathrm{E}-07$ & $2.400 E-09$ & 1. $64 \mathrm{E}+01$ & & \\
\hline WSW & 1.03 & $7.461 \mathrm{E}-07$ & $7.423 \mathrm{E}-07$ & $6.508 \mathrm{E}-07$ & $4.307 E-09$ & $3.21 E+01$ & & \\
\hline W & 1.29 & $4.172 E-07$ & $4.144 \mathrm{E}-07$ & $3.580 E-07$ & $2.064 E-09$ & $1.68 \mathrm{E}+01$ & & \\
\hline WNW & 1.43 & $3.380 \mathrm{E}-07$ & $3.353 \mathrm{E}-07$ & $2.874 \mathrm{E}-07$ & $1.522 \mathrm{E}-09$ & $1.31 \mathrm{E}+01$ & & \\
\hline NW & 4.99 & $9.343 \mathrm{E}-08$ & $9.097 \mathrm{E}-08$ & $6.913 \mathrm{E}-08$ & $2.326 \mathrm{E}-10$ & $2.78 \mathrm{E}+00$ & & \\
\hline NNW & 4.97 & $1.012 \mathrm{E}-07$ & $9.873 \mathrm{E}-08$ & $7.499 E-08$ & $2.904 E-10$ & $3.13 \mathrm{E}+00$ & & \\
\hline
\end{tabular}


MAXDOSE-SR: A ROUTINE RELEASE ATMOSPHERIC DOSE MODEL USED AT $\underline{\text { SRS }}$

\section{DISTRIBUTION (12)}

S. Wood, 773-A

D. B. Moore-Shedrow, 773-A

J.B. Gladden, 773-42A

G.T. Jannik, 773-42A

A. A. Simpkins, $773-42 \mathrm{~A}$

SRTC Records(4), 773 - 52A

ED Records(3), 773 - 42A 